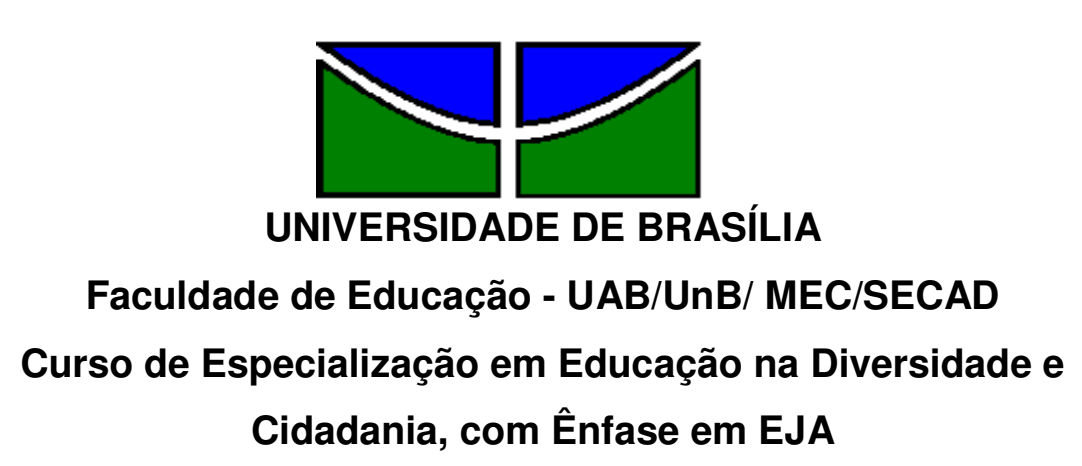

Cidadania, com Ênfase em EJA

\begin{abstract}
Alfa Rodrigues Barbosa de Sousa, Ana Clara Urupá Moraes de Lima, Carla Andréia Simão dos Santos, Joelma de Oliveira Moura, Marilda Santos de Souza, Maria Helena Pereira e Maria José Gonçalves Ferreira da Silva
\end{abstract}

\title{
O Educando com Déficit Intelectual da Educação de Jovens e Adultos no contexto: mundo do trabalho
}

BRASÍLIA, DF 


\title{
UNIVERSIDADE DE BRASÍLIA \\ Faculdade de Educação - UAB/UnB/ MEC/SECAD \\ Curso de Especialização em Educação na Diversidade e Cidadania, com Ênfase em EJA
}

\section{O Educando com Déficit Intelectual da Educação de Jovens e Adultos no contexto: mundo do trabalho}

\author{
Alfa Rodrigues Barbosa de Sousa, Ana Clara Urupá Moraes de Lima, \\ Carla Andréia Simão dos Santos, Joelma de Oliveira Moura, Marilda Santos de Souza, \\ Maria Helena Pereira e Maria José Gonçalves Ferreira da Silva
}

Maria Luiza Pereira Angelim

Maria do Socorro da Silva Linhares

PROJETO DE INTERVENÇÃO

BRASÍLIA, DF 


\title{
UNIVERSIDADE DE BRASÍLIA \\ Faculdade de Educação - UAB/UnB/ MEC/SECAD \\ Curso de Especialização em Educação na Diversidade e \\ Cidadania, com Ênfase em EJA
}

Alfa Rodrigues Barbosa de Sousa, Ana Clara Urupá Moraes de Lima, Carla Andréia Simão dos Santos, Joelma de Oliveira Moura, Marilda Santos de Souza, Maria Helena Pereira e Maria José Ferreira Gonçalves

\section{O Educando com Déficit Intelectual da Educação de Jovens e Adultos no contexto: mundo do trabalho}

Trabalho de conclusão do Curso de Especialização em Educação na Diversidade e Cidadania, com Ênfase em EJA, como parte dos requisitos necessários para obtenção do grau de Especialista na Educação de Jovens e Adultos

\author{
Maria Luiza Pereira Angelim \\ Professor Orientador \\ Maria do Socorro da Silva Linhares \\ Tutor Orientador
}

Carla Castelar Q. de Castro

Avaliador Externo

BRASÍLIA, DF Julho/2010 
Dedicamos, primeiramente a Deus, não só pela força e luz que ELE nos dispensa a cada instante de vida, como também pelas Famílias maravilhosas que nos concedeu. Famílias que sempre podemos contar e torcem por nossos sucessos. Em segundo, agradecemos ao nosso espaço de trabalho e aos nossos alunos que são o foco desta construção. 


\section{AGRADECIMENTO}

Nossos agradecimentos aos coordenadores, professores - orientadores e professores tutores do curso pelo empenho que demonstraram ao longo do curso. Aos colegas cursistas, em especial aos da nossa turma: "C" e "G", pelas interações e contribuições em fóruns. Caloroso agradecimento a professora - tutora Maria do Socorro pelo empenho, dedicação, atenção e pelas várias vezes que nos despertou para construção do conhecimento em ambiente educativo. Agradecemos, ainda, a equipe gestora, professores, alunos e pais dos alunos do Centro de Ensino Especial 02 de Ceilândia DF, pois estes, de forma direta e indireta foram grandes contribuidores ao nosso trabalho. Obrigada! 
"A principal meta da educação é criar homens capazes de fazer coisas novas, não simplesmente repetir o que outras gerações já fizeram. Homens que sejam criadores, inventores, descobridores. A segunda meta da educação é formar mentes que estejam em condições de criticar, verificar e não aceitar tudo que elas se propõem."

(Jean Piaget) 


\section{RESUMO}

Desde o início da história humanidade até a atualidade, a família, a escola e a sociedade vivenciam uma relação que se transforma em função das novidades do cotidiano. Nesse sentido, este trabalho refere-se ao processo de inclusão dos alunos da Educação de Jovens e Adultos (EJA) com Déficit Intelectual (DI) e as dificuldades encontradas ao longo desse processo de inserção no mundo do trabalho conforme assegura a legislação vigente. Durante muito tempo o portador de necessidades educacionais especiais foi discriminado, abandonado e esquecido. Entidades não governamentais, pais e algumas autoridades começaram a se reunir para proclamarem e reivindicarem direitos iguais para essas pessoas. Em 1994, na cidade da Salamanca na Espanha, aconteceu à Conferência Mundial sobre Necessidades Educativas Especiais. Foi representado por 92 governos e 25 organizações internacionais. Por meio desta declaração reafirmavam o compromisso com a Educação para Todos, reconhecendo a necessidade e a urgência do ensino ser ministrado, no sistema comum de educação, a todas as crianças, jovens e adultos com necessidades educativas especiais. Nesse ínterim, pode-se afirmar que este projeto vislumbra por uma educação que fortaleça a identidade da escola e tenha como objetivo a formação para a vida, tendo com base a cidadania, o respeito à diversidade e o apoio a inclusão. A escola representada pelos docentes, gestores e conselho escolar deve promover ações para construção de tais concepções no ambiente escolar. Assim, esse projeto primou por pesquisar os aspectos da realidade do Centro de Ensino Especial 02, envolvendo a EJA com Déficit Intelectual no contexto: mundo do trabalho. Para perceber a dinâmica in loco foi observado a prática pedagógica das docentes em Educação de Jovens e Adultos por meio de relatos de experiências, além da promoção de debate com docentes do Centro envolvidos nos atendimentos aos alunos da EJA com DI. O estudo realizado neste trabalho permitiu a ampliação e esclarecimento de conceitos e princípios que estão relacionados a inserção do educando no mundo do trabalho além de revelar o comportamento da sociedade em relação a pessoa com DI quando estes são inseridos no mercado de trabalho. Para a realização e desenvolvimento deste estudo foi utilizada a pesquisa bibliográfica com o uso de material já elaborado na área, constituído principalmente de leis, documentos da SEEDF, livros e artigos já publicados pelos diversos autores que tratam do tema, o que evidenciou os seguintes questionamentos: como a escola tem efetivado suas ações juntamente com as demais instituições para favorecer a integração do educando no mundo de trabalho? Por que o educando da EJA com déficit intelectual não é contemplado no mercado de trabalho? Como objetivo geral tende a evidenciar os caminhos para que os estudantes de EJA com deficiência intelectual (DI) possam ser inseridos no mundo do trabalho de forma representativa e efetiva. Objetivos específicos: identificar os espaços de apoio que promovam a inserção do estudante de EJA/DI no mundo do trabalho e buscar recursos no espaço escolar que possibilitem a inserção no mundo de trabalho para os estudantes da EJA/DI.

Palavras - Chaves: EJA - Déficit Intelectual - Mundo do Trabalho 


\section{LISTA DE ABREVIATURAS}

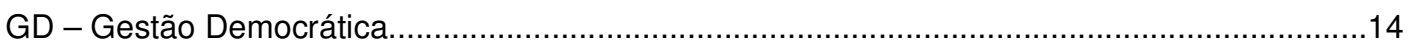

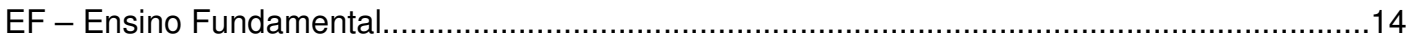

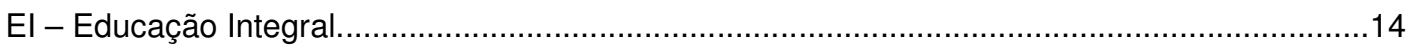

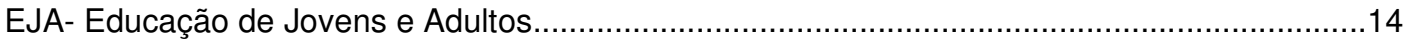

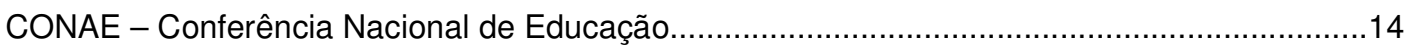

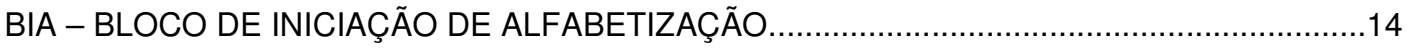

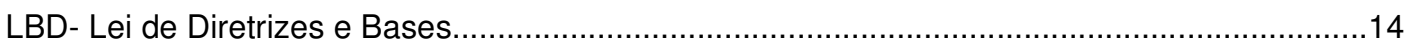

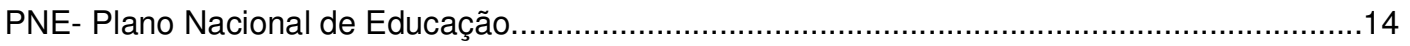

SEEDF - Secretaria de Estado e Educação do Distrito..................................................................15

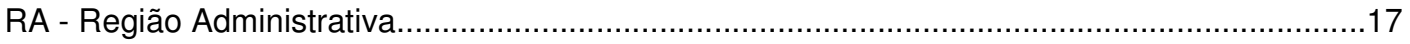

CODEPLAN:Companhia do Desenvolvimento do Planalto Central..............................................17

SHIS -Programa Habitacional:Sociedade de Habitação de Interesse Social...............................18

IBGE - Instituto Brasileiro de Geografia e Estatística.............................................................18

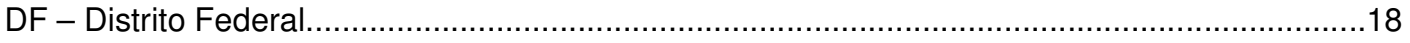

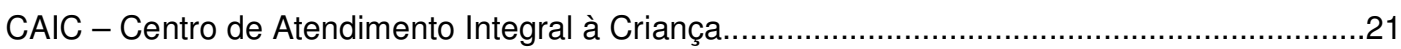

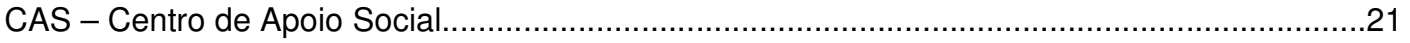

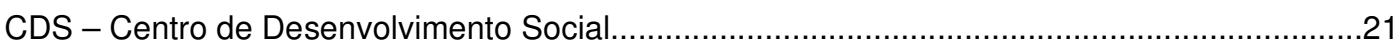

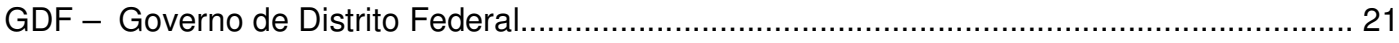

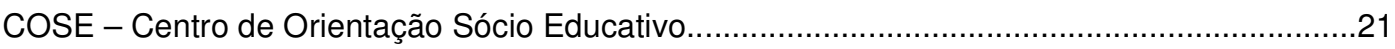

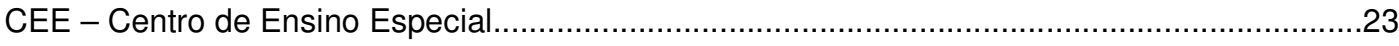

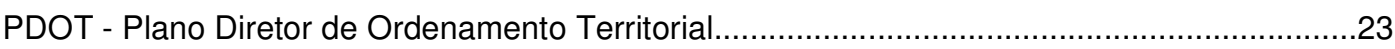

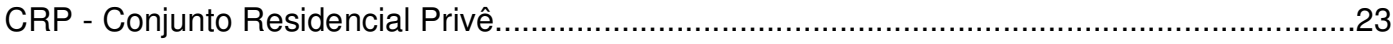

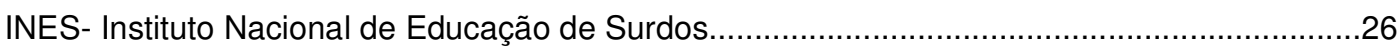

CORDE:Coordenadoria Nacional para Integração da Pessoa Portadora de Deficiência.............27

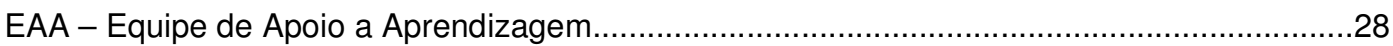

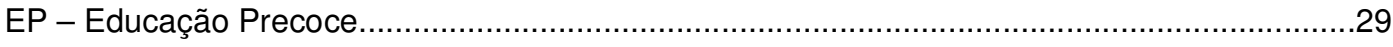

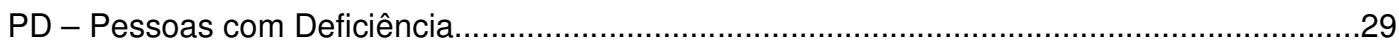


PCN - Parâmetros Curriculares Nacionais...............................................................29

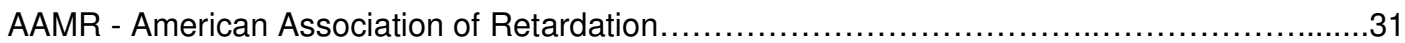

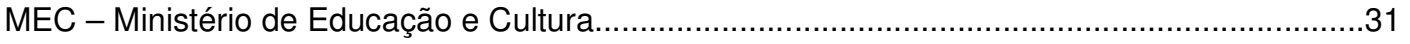

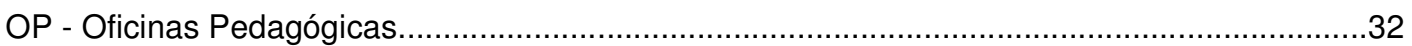

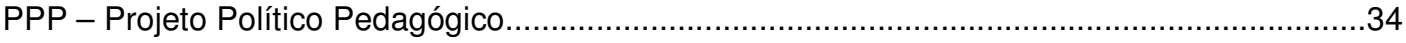

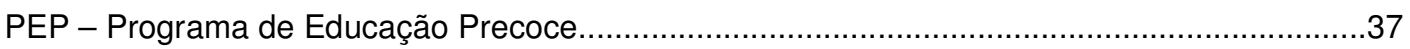

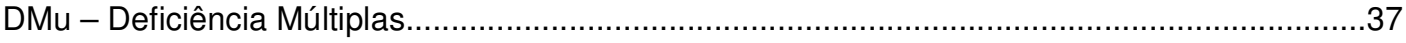

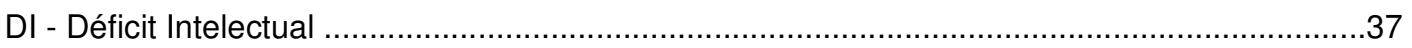

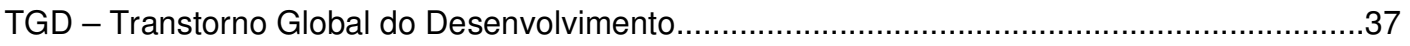

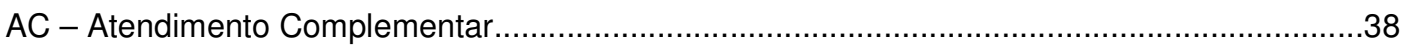

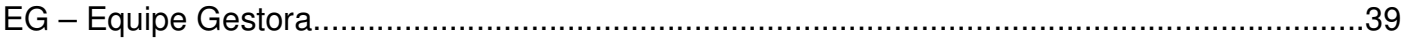

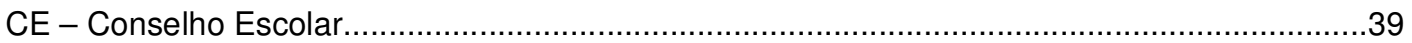

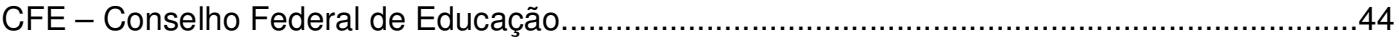

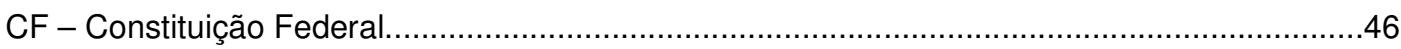

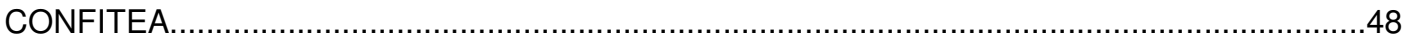




\section{FIGURAS}

Figura 1 - Localização do CEE 02 de Ceilândia...................................................................17

Figura 2 - Mapa das Quadras de Ceilândia.........................................................................

Figura 3 - Mapa de Localização de Ceilândia..................................................................... 19

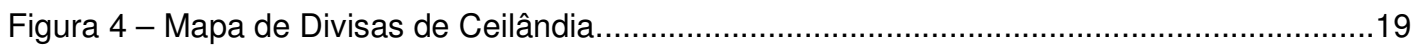

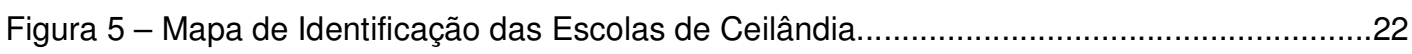

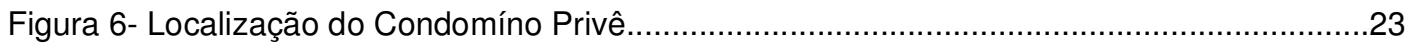

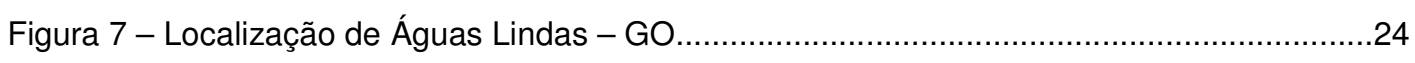




\section{GRÁFICOS}

Gráfico 1 - Aspectos Econômicos de Ceilândia...........................................20 


\section{TABELA}

Tabela 1 - Aspectos do processo educacional de Ceilândia...

Tabela 2 - Dados de matrículas do CEE 02 segundo SGE... 


\section{SUMÁRIO}

INTRODUÇÃO

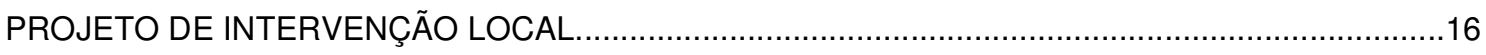

1. DADOS DE IDENTIFICAÇÃO DO PROPONENTE........................................................16

2. DADOS DE IDENTIFICAÇÃO DO PROJETO DE INTERVENÇÃO.......................................17

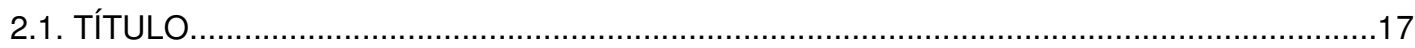

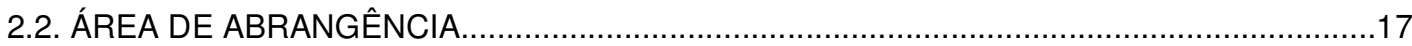

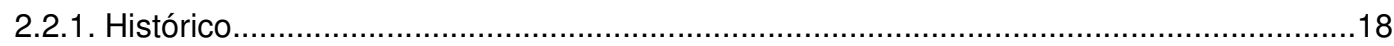

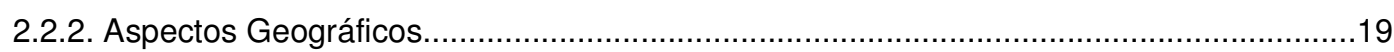

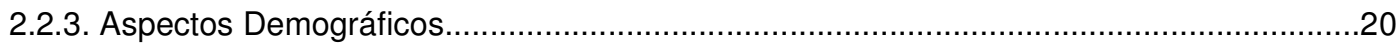

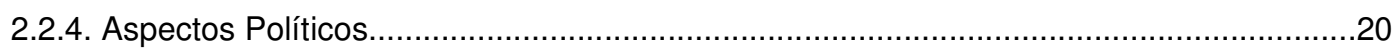

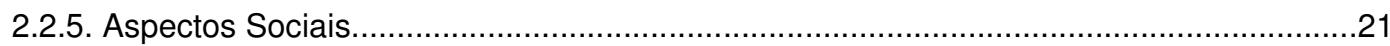

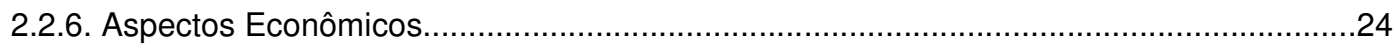

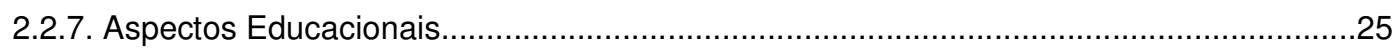

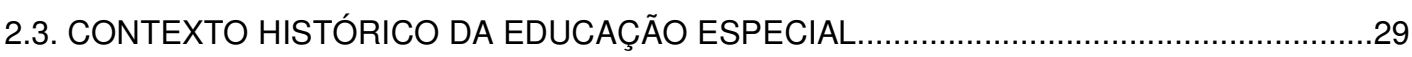

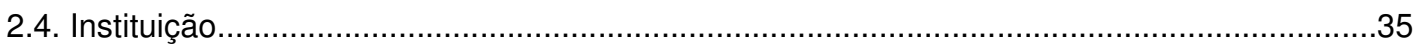

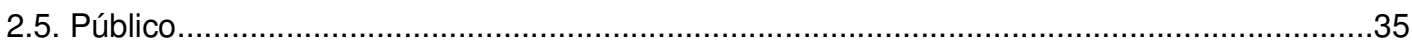

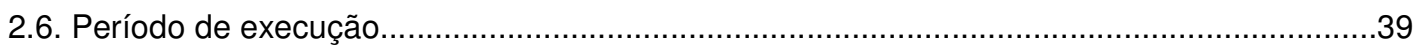

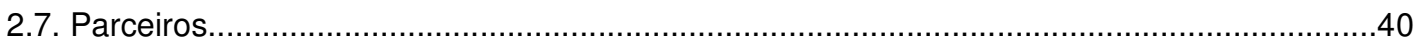

3. AMBIENTE INSTITUCIONAL

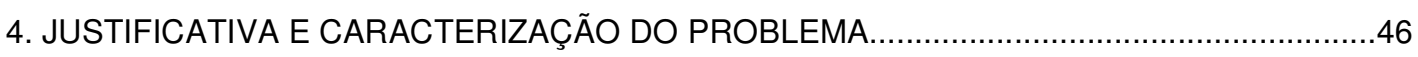

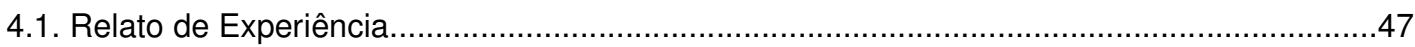

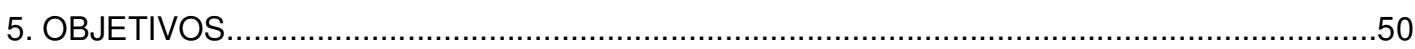

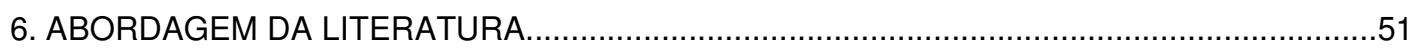

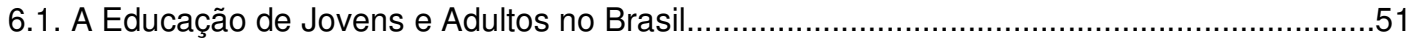

6.2. Breve histórico sobre a Educação de Jovens e Adultos no Brasil...........................................55

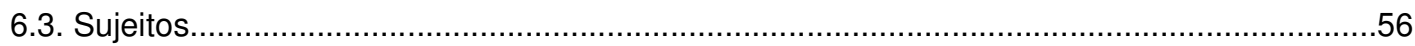

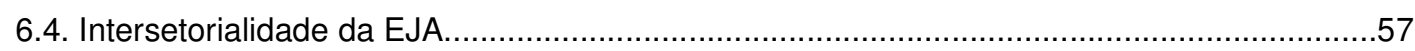

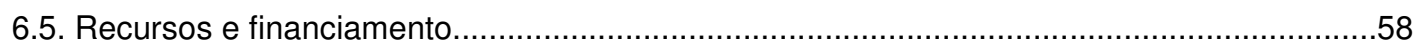

6.6. EDUCAÇÃO ESPECIAL - EJA NO CONTEXTO MERCADO DE TRABALHO.......................59

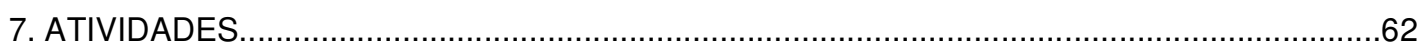

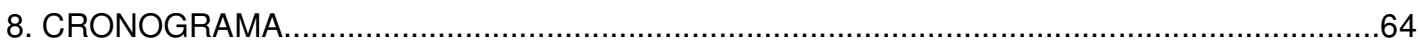

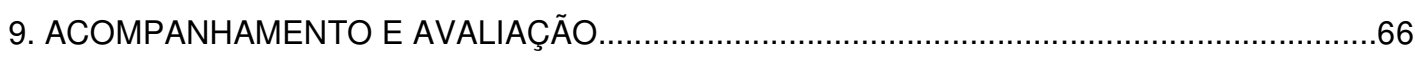

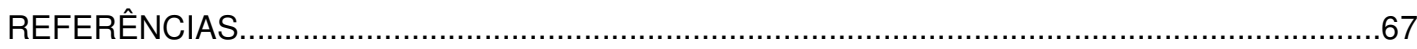

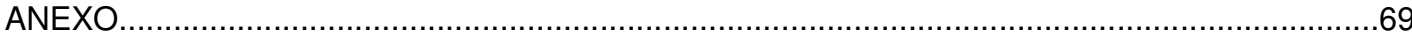




\title{
INTRODUÇÃO
}

A busca por uma escola de qualidade para todos é uma história, tendo sido defendida pelos movimentos sociais organizados de pais, trabalhadores em educação e sociedade em geral. Na década de setenta a preocupação girava em torno da necessidade de ampliação de acesso; na década de 80 a Gestão Democrática (GD) passou a integrar o debate nacional e, na década de noventa até os dias atuais, o foco tem sido a busca por uma educação de qualidade para todos. Essas lutas foram compartilhadas pelos educadores do Distrito Federal. Nesse ínterim, surge a ampliação do Ensino Fundamental (EF) para nove anos, a Educação Integral (EI) e a maior atenção a modalidade de Educação de Jovens e Adultos (EJA) que representa uma conquista da sociedade e principalmente de toda a comunidade ao encontro da qualidade na educação. Tal afirmativa pode ser confirmada pela Conferência Nacional de Educação CONAE (2010, p.27):

\begin{abstract}
A organização dos/as trabalhadores/as em educação, articulada com os demais segmentos da sociedade civil organizada, na luta em defesa da qualidade social das instituições de ensino públicas, tem contribuído, historicamente, na busca de alternativas, políticas e ações nas esferas de governo - Federal, Estadual/DF e Municipal - direcionadas a estabelecer ações coordenadas para a elaboração de uma agenda mínima de fortalecimento da educação básica e superior.
\end{abstract}

Com a ampliação do Ensino Fundamental para nove anos no DF e com a implantação do Bloco Inicial de Alfabetização (BIA), constitui uma política nitidamente comprometida com a inclusão e a igualdade. A ampliação do período de escolaridade obrigatória, que assegura o acesso da criança de seis anos à escola e aumenta suas chances de sucesso escolar nos anos seguintes do Ensino Fundamental, está legalmente respaldada. Sabe-se que esta ampliação não é algo novo no país, estando prevista inclusive, nas Diretrizes e Bases da Educação Nacional LDB, Lei no. 9.394|96, tornando-se uma das metas do Plano Nacional de Educação - PNE, Lei no. 10.172|02. É pertinente afirmar que o atendimento à criança de seis anos no Ensino Fundamental de nove anos é uma realidade em alguns Estados brasileiros, bem como em outros países da América do Sul.

Além da EF de nove anos, o Governo do Distrito Federal elegeu a Educação Integral como uma das prioridades para o período de 2007/2010, tendo como principal meta o desenvolvimento de uma educação de qualidade em que educação básica deve priorizar a formação de cidadãos pela conquista de autonomia, senso reflexivo e propiciar ao educando a construção de conhecimentos, atitudes e valores que o tornem solidário, crítico, criativo, participativo e ético. (Diário Oficial-DF no 234, 04 de dezembro de 2009 - ANEXO EDUCAÇÃO INTEGRAL: AMPLIANDO TEMPOS, ESPAÇOS E OPORTUNIDADES EDUCACIONAIS - 1. Educação Integral: uma construção coletiva). 
Diante o exposto, a Secretaria de Estado e Educação do Distrito Federal (SEEDF), entende a Educação Integral como mecanismo que oferecerá condições e oportunidades educativas que atenda a demanda da Educação do DF. Dentre as prioridades acima citadas faz parte de tal contexto a Educação de Jovens e Adultos, dadas as especificidades desta modalidade que em nenhum momento ficou a margem das indagações, preocupações e da busca de qualidade de ensino. A SEEDF está em consonância com as orientações da Política Nacional de Educação no que se refere à EJA, estando em parceria ao que diz a LDB Lei № 9394/96:

Art. $4^{\circ}$, VII - oferta de educação escolar regular para jovens e adultos, com características e modalidades adequadas às suas necessidades e disponibilidades, garantindo aos que forem trabalhadores as condições de acesso e permanência na escola.

Art. $37 \mathrm{~A}$ educação de jovens e Adultos será destinada àqueles que não tiveram acesso ou continuidade de estudos no fundamental e médio na idade própria. (LDB 9394/96).

Para reforçar os artigos acima que garantem a oferta de educação, conta-se com o documento da CONAE (2010) que apresenta preocupação com qualidade, acesso e permanência em espaço escolar, respeitando a diversidade e com vistas a exclusão da desigualdade.

Como direito social, avulta, de um lado, a defesa da educação pública, gratuita, laica, democrática, inclusiva e de qualidade social para todos/as e, de outro, a universalização do acesso, a ampliação da jornada escolar e a garantia da permanência bem-sucedida para crianças, adolescentes, jovens e adultos/as, em todas as etapas e modalidades. Este direito se realiza no contexto desafiador de superação das desigualdades e do reconhecimento e respeito à diversidade. (CONAE, 2010 p.29).

A educação associada a igualdade, a diversidade e a inclusão visa oportunizar condições educativas para todos, dentre vários grupos está a modalidade de Educação Especial - CONAE (2010):

Para isso, propõe-se a disseminação de política direcionada à transformação dos sistemas educacionais em sistemas inclusivos, que contemplem a diversidade com vistas à igualdade(...). Isto deve ter como princípio a garantia do direito à igualdade e à diversidade étnico-racial, de gênero, de idade, de orientação sexual e religiosa, bem como a garantia de direitos aos/às estudantes com deficiência, transtornos globais do desenvolvimento e altas habilidades/superdotação. (CONAE, 2010 p.71)

Em síntese, a educação passou não só universalizar o acesso, mas percebeu a todos como sujeitos dotados de direito e que podem no processo educativo encontrar mecanismos em busca do sucesso em diversos campos. 


\section{PROJETO DE INTERVENÇÃO LOCAL - PIL}

\section{DADOS DE IDENTIFICAÇÃO DOS PROPONENTES}

1.1. Nome

- Alfa Rodrigues Barbosa de Sousa

- Ana Clara Urupá Moraes de Lima

- Carla Andréia Simão dos Santos

- Joelma de Oliveira Moura

- Marilda Santos de Souza

- Maria Helena Pereira

- Maria José Gonçalves Ferreira da Silva

1.2. Identificação da Turma

- Turma - C

- Turma - G

1.3. Informações para Contato

Telefones:

- Alfa Souza

6181808022

- Ana Clara

6191048239

- Carla Andréia

6185682032

- Joelma de Oliveira

- Marilda dos Santos

- Maria Helena

- Maria José
6196552633

6193031435

6133710399

6196857349 alfa.sousa@hotmail.com

anaurupa@yahoo.com.br

carlahandry@gmail.com

jjom_df@hotmail.com

marildinha.souza@gmail.com

mariahelena_10b@hotmail.com

zezegferreira@yahoo.com.br 


\section{DADOS DE IDENTIFICAÇÃO DO PROJETO}

2.1. Título: O Educando com Déficit Intelectual em EJA no contexto: mundo de trabalho

2.2. Área de abrangência:

( ) Nacional ( )Regional ( ) Estadual ( ) Municipal () Distrital ( x ) local ${ }^{1}$

O Projeto de Intervenção Local será desenvolvido no Centro de Ensino Especial 02, localizado na IX Região Administrativa (RA) do Distrito Federal, Ceilândia, situado na QNO 12 - Área Especial "G" - Setor "O".

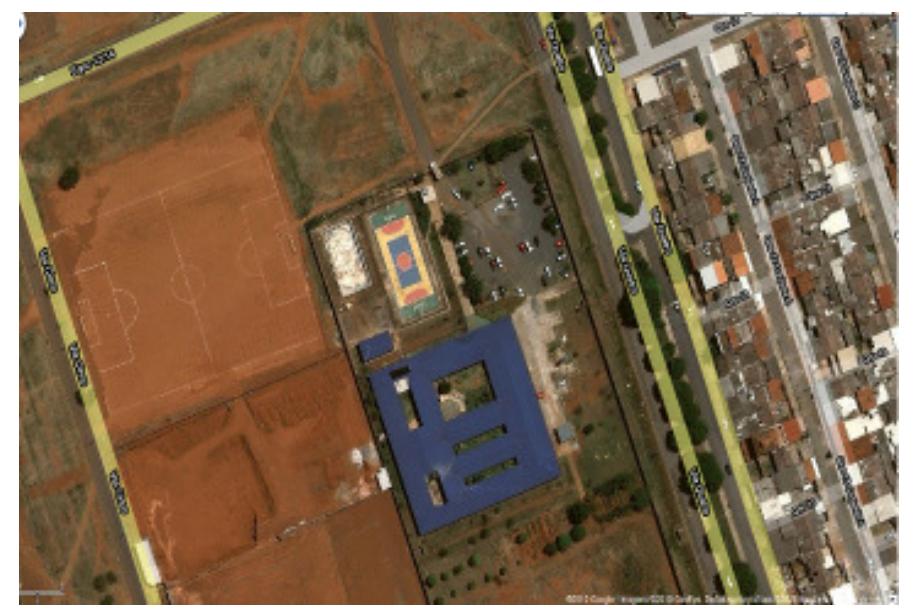

Figura 1- localização do CEE 02 de Ceilândia

A IX RA é uma cidade em pleno desenvolvimento, possui representatividade significativa nas diversas ações promovidas pelo Distrito Federal. Para melhor clareza faz-se necessário elencar alguns dados históricos, sociais, econômicos, educacionais e geográficos sobre esta RA. Os dados abaixo apresentados são fundamentados nas informações divulgadas pela Companhia do Desenvolvimento do Planalto Central (Codeplan), criada em 1966, que possui papel relevante no Governo do Distrito Federal. Sua atuação abrange as áreas de pesquisas, estudos, análises e serviços de informática, subsidiando as ações do governo e disseminando informações para a sociedade.

\footnotetext{
${ }^{1}$ http://wikimapia.org/7225513/pt/Centro-de-Ensino-Especial-02-da-Ceil\%C3\%A2ndia
} 


\subsubsection{HISTÓRICO}

Segundo a Codeplan (2010) o nome "Ceilândia" teve origem na junção da sigla CEI Comissão de Erradicação de Invasões, com o sufixo "lândia". A cidade de Ceilândia é o resultado do primeiro projeto de erradicação de favelas que aconteceu no Distrito Federal. Criada em março de 1971. O projeto da cidade foi elaborado pelo arquiteto Ney Gabriel.

A chegada constante de novos migrantes em Ceilândia e a criação do Programa Habitacional da Sociedade de Habitação de Interesse Social (SHIS) obrigou o governo a criar novas áreas em Ceilândia. Assim, em 1976 foi criada Quadra Norte "O" (QNO), conhecida como Setor "O”. Em 1977, criou-se o Núcleo Guariroba, situado na Ceilândia Sul e em 1979 foram criados os setores "P" Norte e "P" Sul. Em 1985, surgiu a Expansão do Setor "O". Ceilândia passa contar com Setor "N" em 1998, Setor "P" Sul em 1989, Setores QNQ e QNR em 1992.

A Ceilândia é composta pelas quadras: QNM, QNN, QNO, QNP, QNQ, QNR, dispostas em torno de dois eixos que se cruzam em um ângulo de $90^{\circ}$. Conta ainda com o Condomínio Privê, Setor de Chácaras e Setor Industrial.

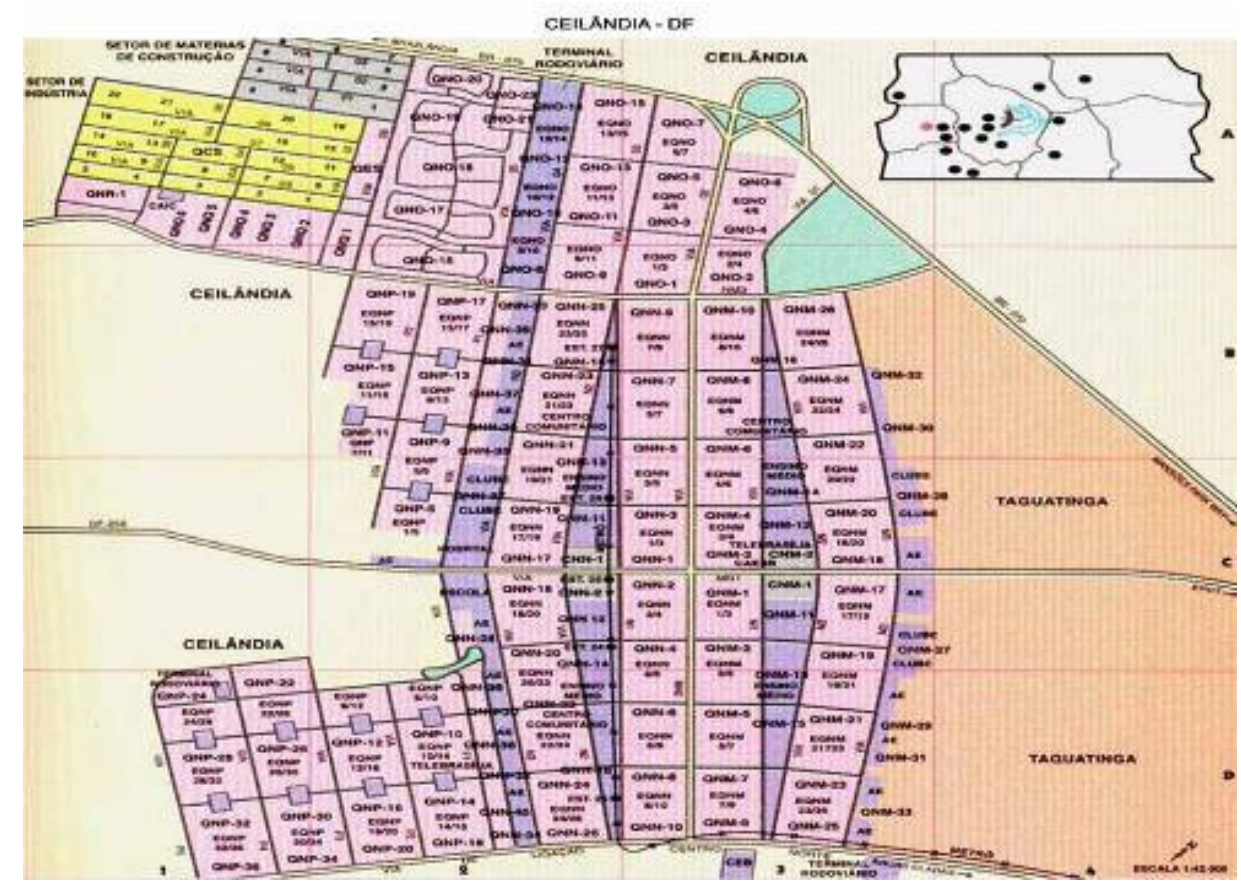

Figura 2- mapa das quadras de Ceilândia

\footnotetext{
${ }^{2}$ Fonte: http://maps.google.com.br/
} 
A RA IX foi criada pela Lei № 49/89 e o Decreto № 11.921/89. Por força do Decreto 10.348/87 de 28 de abril de 1987 ficou definido como data da fundação de Ceilândia o dia 27 de março de 1971. Anteriormente, Ceilândia estava incluída na RA III: Taguatinga, devido sua significativa expansão fez-se necessário o surgimento da IX RA.

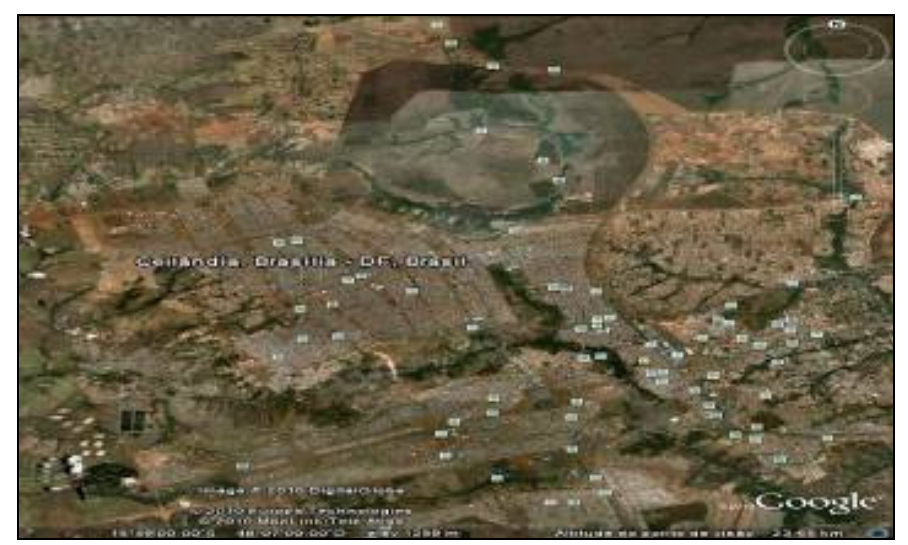

Figura 3 - mapa de localização de Ceilândia

\subsubsection{ASPECTOS GEOGRÁFICOS}

Em relação aos aspectos geográficos, segundo dados atualizados da CODEPLAN (2010), verifica-se que Ceilândia fica localização a 25 km do Plano Piloto, tendo como limites ao Norte: Ribeirão das Pedras e Lago do Descoberto; ao Sul: Córrego Taguatinga e Rio; a Leste: Linha que une a Barra do Córrego Currais até o Córrego Taguatinga; e a Oeste: Rio Descoberto/ Estado de Goiás.

Quanto à altitude situa-se entre 1000 e 1200 metros na zona urbana. O clima é considerado tropical semi-úmido. A temperatura média $21^{\circ} \mathrm{C}$. Precipitação pluviométrica é de $1,75 \mathrm{~mm}$. A umidade relativa do ar oscila entre $60 \%$ a menos de $20 \%$ em alguns períodos da tarde. O relevo, em sua maioria, possui características de Chapadões sedimentares arenosos. A Vegetação tem peculiaridades do cerrado, que é formado por duas camadas: gramíneas e arbustos.

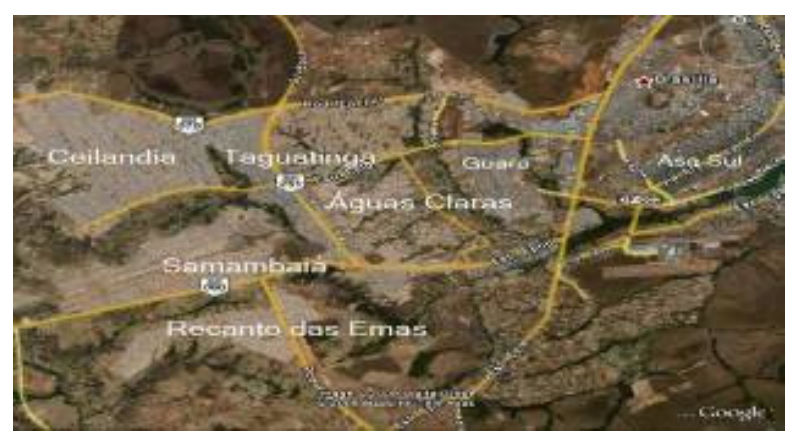

Figura 4 - mapa de divisas de Ceilândia 


\subsubsection{ASPECTOS DEMOGRÁFICOS}

Com base no último senso realizado pelo Instituto Brasileiro de Geografia e Estatística (IBGE), Ceilândia possui mais de 350 mil habitantes, o que representa $18 \%$ da população do Distrito Federal (DF). É a RA com o maior número de comerciários do DF (100 mil), possui uma população economicamente ativa de 160 mil pessoas. Verifica-se também uma grande quantidade de feiras na região, como a Feira Central - a principal - exemplo de um empreendimento informal, pelo qual a cidade também pode se fortalecer. A População em geral é formada por homens 166.212 e mulheres 176.622 , sendo $45 \%$ da população menores de 20 anos. A formação por família (quantidade) está na média de 4,87 membros. A renda familiar varia conforme o gráfico abaixo:

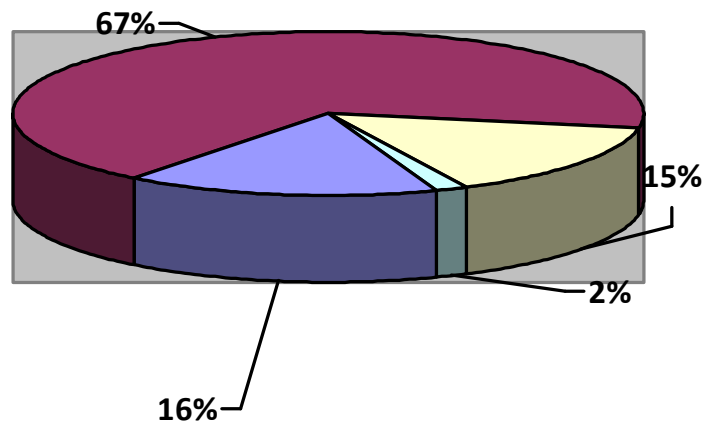
$\square$ Até 02 salários mínimos
$\square$ De 02 a 10 salários mínimos
$\square$ De 10 a 25 salários mínimos
$\square$ Acima de 25 salários mínimos

Gráfico 1 - Aspectos econômicos de Ceilândia, Codeplan 2010.

\subsubsection{ASPECTOS POLÍTICOS}

Dados da CODEPLAN (2010) registram Ceilândia como o maior colégio eleitoral do Distrito Federal, tendo 263.000 eleitores. Possui as seguintes zonas eleitorais:

- 8a Zona - Ceilândia Norte e parte do P Norte:

- $2^{\text {a } Z o n a ~-~ C e i l a ̂ n d i a ~ S u l ~ e ~ p a r t e ~ d a ~ G u a r i r o b a ; ~}$

- 16a Zona - P Norte, Setor O, Expansão do Setor O, QNQ, QNR, condomínio Privê, INCRA 09 e demais áreas rurais da cidade;

- 20ㅡㅡㄴ Zona - P Sul e parte da Guariroba. 


\subsubsection{ASPECTOS SOCIAIS}

A cidade é formada com o maior número de entidades comunitárias, num total de 154, com elevado índice de organização de movimento popular em termo de reivindicações. A saber:

- 02 Centros de Referência da Especializado em Assistência Social - CREA - O Centro de Referência Especializado de Assistência Social é um unidade responsável pelo acolhimento e triagem da população infanto-juvenil em extremo risco social, contribuindo para o desenvolvimento das crianças e adolescente em situação de risco físico ou que tenham seus direitos constitucionais violados. Por meio de acompanhamento psicossocial, os jovens cadastrados, juntamente com suas famílias, recebem apoio, serviços de orientação psicossocial e participam de oficinas laborativas e lúdicas, ajudando a elevar sua auto-estima.

- 02 Centros de Referência de Assistência Social (CRAS) - é uma unidade pública estatal descentralizada da política de assistência social, responsável pela organização e oferta de serviços da proteção social básica do Sistema Único de Assistência Social (SUAS) nas áreas de vulnerabilidade e risco social dos municípios e DF. Dada sua capilaridade nos territórios, se caracteriza como a principal porta de entrada do SUAS, ou seja, é uma unidade que propicia o acesso de um grande número de famílias à rede de proteção social de assistência social.

- 03 Centros de Orientação Sócio-Educativo (COSE) - trabalha com as questões socioeducativos. O atendimento a Crianças e adolescentes através dos COSES é efetivado por 13 centros, localizados em Brasília (1), Ceilândia (3), Gama (2), Guará (1), Núcleo Bandeirante (1), Planaltina (1), Taguatinga (2), Samambaia (1), e Sobradinho (1), no período extra-escolar. Nos COSES são desenvolvidas atividades desportivas, recreativas, culturais e de iniciação profissional bem como fornecimento alimentação.

- 02 Centros de Atendimento Integral à Criança (CAIC) - nos dias atuais o CAIC funciona de forma reduzida atendendo alunos nos dois períodos e com a manutenção de alguns projetos. Pode-se dizer que o objetivo inicial relacionado a forma de atendimento que deveria ser oferecido ao educando do CAIC tem sido reduzido em função de vários fatores sociais, políticos e econômicos. 
- 01 Centro de Apoio Social (CAS) - programa atende a migrantes, população de rua, pessoas em tratamento de saúde e população local através do abrigamento, concessão de passagens para retorno ao local de origem, medicação, vestuário e atendimento as suas necessidades básicas.

- 06 Creches - ONGs - O atendimento prestado por este programa destina-se a crianças de zero a seis anos de idade, pertencentes a famílias de baixa renda. Consiste na garantia de direitos fundamentais no que tange à satisfação de suas necessidades básicas e a proteção e estimulação para o seu crescimento e desenvolvimento.

- Escolas públicas - na Região Administrativa de Ceilândia encontram-se várias escolas públicas que oferecem todas as modalidades de ensino nos turnos: matutino, vespertino e integral. Conforme o Regimento Escolar das Instituições Públicas da SEEDF (2009, p. 11-12) entende-se:

Art. $2^{\circ}$ As instituições educacionais da Rede Pública de Ensino integram a estrutura da Secretaria de Estado de Educação, unidade integrante do Governo do Distrito Federal, e são vinculadas pedagógica e administrativamente às respectivas Diretorias Regionais de Ensino, unidades orgânicas administrativas.

Art. 3 As instituições educacionais, de acordo com suas características organizacionais de oferta e de atendimento, classificam-se em:

I - Centro de Educação Infantil - destinado a oferecer, exclusivamente, a Educação Infantil: creche e pré-escola;

II - Jardim de Infância - destinado a oferecer, exclusivamente, a Educação Infantil, pré-escola;

III - Escola Classe - destinada a oferecer as séries e anos iniciais do Ensino Fundamental, podendo, excepcionalmente, oferecer os $6^{\circ}$ e $7^{\circ}$ anos $/ 5^{\circ}$ e $6^{\circ}$ séries e o $1^{\circ}$ e $02^{\circ}$ Segmentos de Educação de Jovens e Adultos, de acordo com as necessidades da Rede Pública de Ensino do Distrito Federal;

IV - Escola Parque - destinada a oferecer atividades inter-complementares ao currículo desenvolvido em Escolas Classe e em Centros de Ensino Fundamental; $\mathrm{V}$ - Centro de Ensino Fundamental - destinado a oferecer o Ensino Fundamental e o $1^{\circ}$ e $2^{\circ}$ Segmentos da Educação de Jovens e Adultos; 
VI - Centro Educacional - destinado a oferecer as séries/anos finais do Ensino Fundamental, o Ensino Médio e o $2^{\circ}$ e $3^{\circ}$ Segmentos da Educação de Jovens e Adultos;

VII - Centro de Ensino Médio - destinado a oferecer o Ensino Médio e/ou o Ensino Médio Integrado à Educação Profissional e o $3^{\circ}$ Segmento da Educação de Jovens e Adultos;

VIII - Centro de Educação de Jovens e Adultos - destinado a oferecer, exclusivamente, a Educação de Jovens e Adultos nas modalidades presencial, semipresencial e a distância;

IX - Centro de Ensino Especial - destinado a oferecer atendimento, exclusivamente, para alunos da Rede Pública de Ensino, cujas condições requerem apoios específicos e diferenciados daqueles que a escola comum, no momento, pode ofertar ou a alunos matriculados em classes comuns do Ensino Regular para o desenvolvimento de atividades de complementação pedagógica;

$X$ - Centro de Atenção Integral à Criança e ao Adolescente - CAIC - destinado à proteção e à promoção social da criança e do adolescente, bem como à oferta da Educação Infantil e do Ensino Fundamental;

XI - Centro Interescolar de Línguas - destinado a oferecer, exclusivamente, língua estrangeira moderna em caráter de formação complementar aos alunos matriculados a partir da 5o série/6ㅇ ano do Ensino Fundamental e do Ensino Médio da Rede Pública de Ensino, bem como no $2^{\circ}$ e $3^{\circ}$ Segmentos da Educação de Jovens e Adultos.

XII - Centro de Educação Profissional Escola de Música de Brasília- destinado a oferecer a Educação Profissional por meio de cursos e programas de formação inicial e continuada de músicos e a Educação Profissional Técnica de Nível Médio.

Parágrafo único. Qualquer instituição educacional pode oferecer modalidades fora de sua tipologia, em caráter provisório, quando autorizada por ato próprio da Secretaria de Estado de Educação.

Fonte: Regimento Escolar das Instituições Educacionais da Rede Pública de Ensino do Distrito Federal - 5a Edição. Brasília/DF, 2009

- Escolas particulares - Em Ceilândia existem várias escolas particulares que oferecem todas as modalidades de ensino. 


\subsubsection{ASPECTOS ECONÔMICOS}

- Pequenas Indústrias 1200 unidades;

- Quiosques - 800 unidades;

- Ambulantes - 2600 unidades;

- Maior número de atacadista de alimentos;

- Materiais de construção - Cidade com maior número de empresas do ramo;

- Estabelecimentos médios e pequenos - 6000 unidades

- 07 grandes feiras permanentes;

- 3.199 feirantes;

- 12 agências bancárias;

- Administração Federal - 7,9\%;

- Administração Estadual - GDF - 16,74\%;

- Comércio - 20,25\%;

- Transporte, Saúde e Serviços Bancários - 9,74\%;

- Indústria de Transformação e Construção Civil - 8,99\%;

- Serviços Domésticos - 6,06\%;

- Profissionais Liberais/Autônomo 14,75\%;

- Agropecuária - 0,27\%;

- Outros Serviços - 15,65\%. 


\subsubsection{ASPECTOS EDUCACIONAIS}

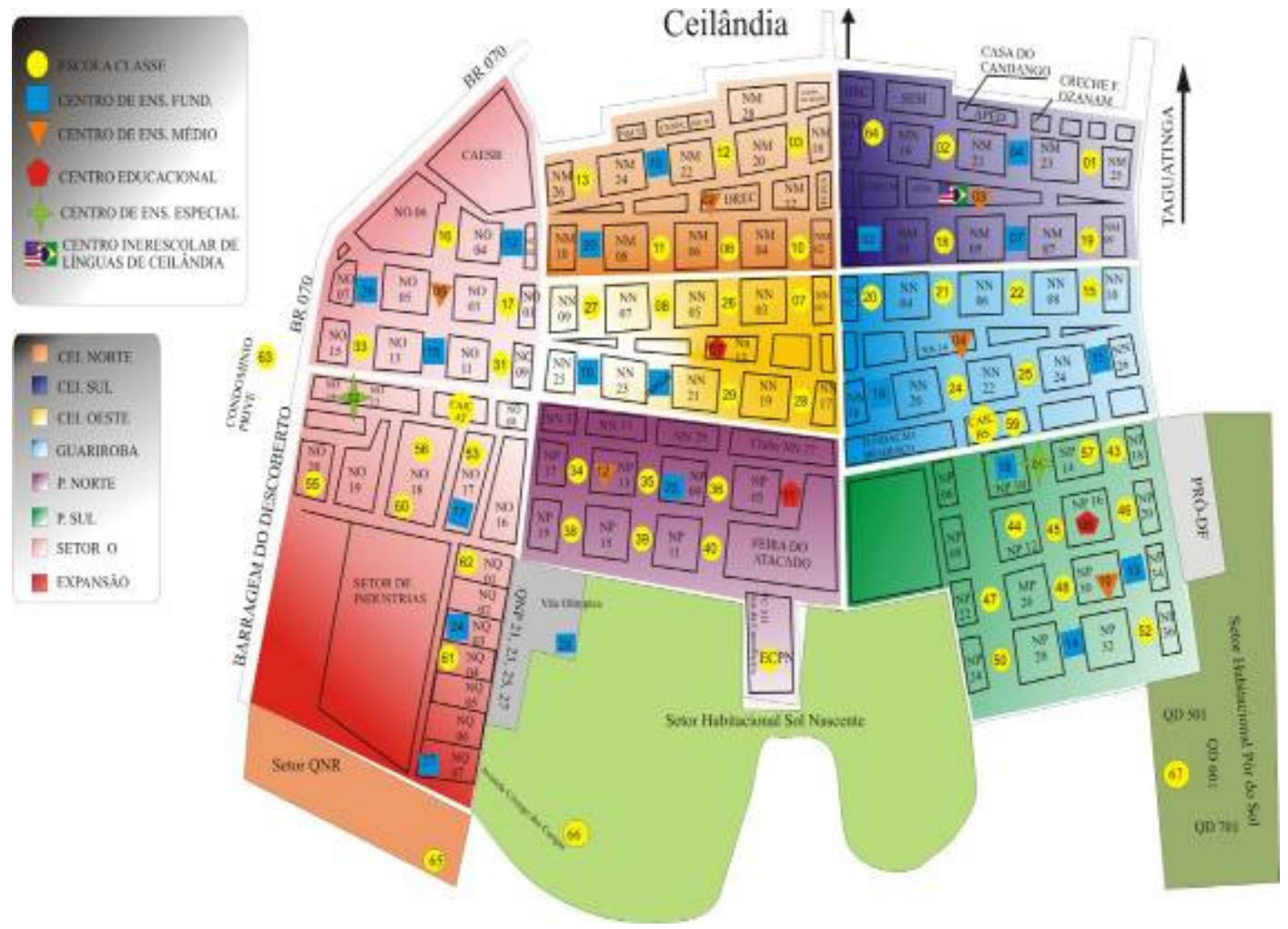

Figura 5 - Mapa de identificação das escolas de Ceilândia Fonte: Diretoria Regional de Ceilândia

Em relação ao processo Educacional observa-se que Ceilândia possui:

\begin{tabular}{|l|r|r|r|r|}
\hline Escola Pública & 87 & 1487 salas de aula & $\begin{array}{r}100.671 \\
\text { alunos }\end{array}$ & 4.273 professores \\
\hline Escola Conveniada & 11 & 137 salas de aula & 4.289 alunos & 159 professores \\
\hline Escola Particular & 44 & 315 salas de aula & 8.176 alunos & 504 professores \\
\hline
\end{tabular}

Tabela 1 - Aspectos do processo educacional de Ceilândia, Codeplan, 2010 
Os alunos matriculados no CEE 02 de Ceilândia, conforme informações constantes no Sistema de Gestão Escolar (SGE) e na secretaria da escola são provenientes:

\begin{tabular}{|c|c|l|}
\hline $\begin{array}{l}\text { Quantidade alunos do } \\
\text { CEE 02 - Ceilândia }\end{array}$ & $\begin{array}{l}\text { Alunos residentes na IX RA } \\
\text { (área Norte de Ceilândia) }\end{array}$ & $\begin{array}{l}\text { Alunos residentes em Águas } \\
\text { Lindas }\end{array}$ \\
\hline 600 & 390 & 210 \\
\hline
\end{tabular}

Tabela 2 - Dados de matrículas do CEE 02 segundo SGE

É importante destacar que Condomínio Privê é um bairro de Ceilândia/DF com aproximadamente 22 anos. Faz parte do Plano Diretor de Ordenamento Territorial (PDOT) de Ceilândia, identificada por Conjunto Residencial Privê (CRP), localizado às margens da BR 070, próximo ao Setor "O” de Ceilândia.

Algumas áreas de Ceilândia estão em processo de regularização, tais como: Condomínio Sol Nascente, Condomínio Privê, Por do Sol e Boa Vista. A RA se tornou um grande atrativo no que se refere à moradia. A região é privilegiada por ser de fácil acesso a duas BRs: 060 e 070.

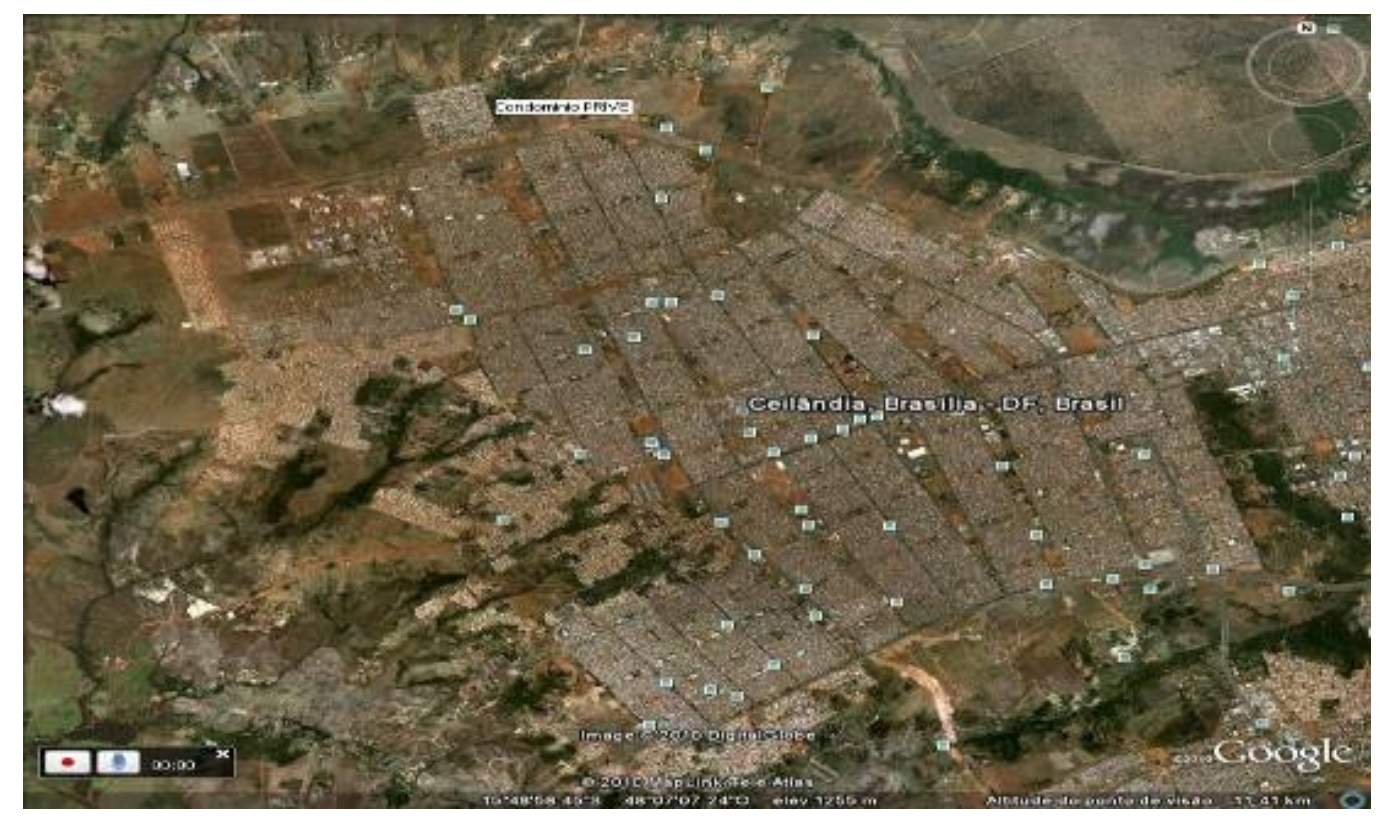

Figura 6- Localização do Condomíno Privê

Além dos alunos residentes na área Norte de Ceilândia, o Centro recebe alunos provenientes de Águas Lindas de Goiás, anteriormente conhecida como Parque da 
Barragem que pertencia ao município de Santo Antônio do Descoberto. Segundo moradores pioneiros, a origem deste nome deve-se a uma homenagem às nascentes Águas Lindas. Há uns 15 anos, havia apenas cerrado, com algumas fazendas e chácaras na região e um clube chamado Águas Lindas.

A existência da rodovia BR-070, corredor de saída de Distrito Federal, propiciou o fluxo de muitas famílias vindas de Brasília e outras cidades próximas, aglutinando-se às suas margens, gerando, posteriormente, a explosão demográfica atual. A emancipação do município se deu após um abaixo assinado conduzido por lideranças locais, esse culminou com o plebiscito no Parque da Barragem, realizado em 12 de outubro de 1995. Em 1996 aconteceu a primeira eleição para o governo municipal. O município não possui um Centro de Ensino Especial, assim os responsáveis buscam por esse atendimento no DF.

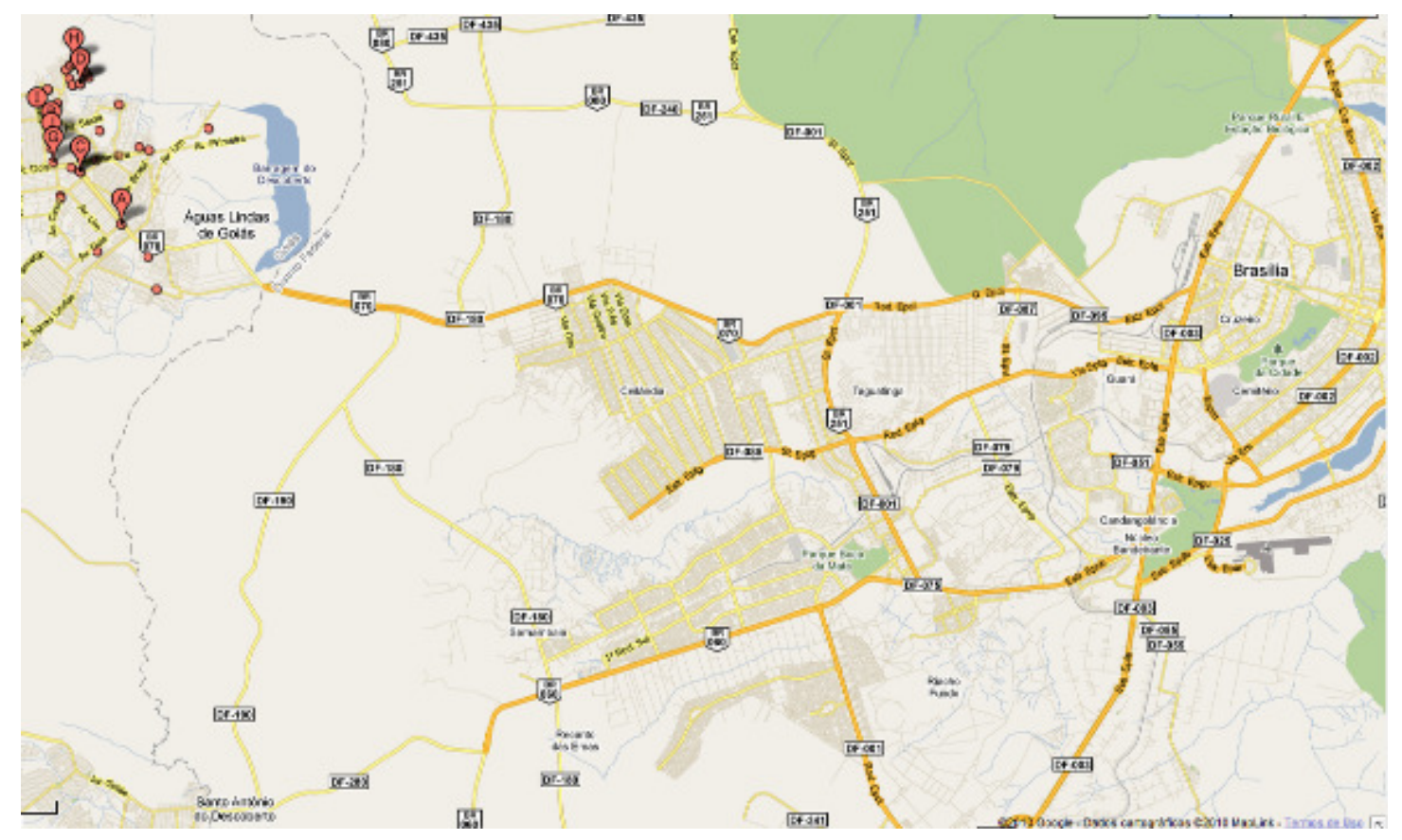

Figura 7 - Localização de Águas Lindas - GO

Tal realidade educativa, em Águas Lindas, reflete em dificuldades que várias famílias enfrentam para manter o aluno participando das atividades pedagógicas proposta pelo Centro. Deve-se ressaltar que o CEE 02 atende vários alunos residentes em Águas Lindas, tendo em vista que esse município ainda não possui um Centro de Ensino Especial que atenda esses educandos. Em função da distância, da falta de recursos econômicos e da falta do benefício do passe livre, muitas vezes, uma pessoa da família destes educandos permanece todo o período de atendimento na escola. Com intuito de promover maior interação da escola com a comunidade que dela participa e com vistas a oportunizar melhor aproveitamento de tempo, a instituição educacional promoveu várias oficinas para os 
acompanhantes que permaneciam na escola. Junto com os projetos surgiram à retratação de outras limitações das famílias dos alunos:

- Nenhum empenho ou falta de condições financeiras para adquirir os materiais das oficinas, sendo que a escola oferecia os materiais de uso coletivo;

- Resistência do grupo em realizar atividades coletivas, prevalecendo à formação de pequenos grupos;

- O receio com o compromisso, pois muitos acompanhantes percebem na escola um ponto de segurança para deixar os alunos, portanto quando eles têm algo para resolver, podem usufruir desses horários, então o compromisso com as oficinas iriam limitar essas oportunidades;

- Para outros, esse é o único momento de relaxar, conversar, ficar a vontade, então não querem nenhum compromisso nestes horários;

- Alguns membros (responsáveis por aluno) não apresentam nenhuma fonte de renda, assim contam com a sensibilidade de alguns segmentos escolar para sanar as necessidades básicas (cestas básicas, remédios, passagens...). A participação nas oficinas indica um caminho para favorecer na renda destas pessoas, assim a não participação pode ser justificada pelo receio de deixarem de receber quando necessário a doação dos mantimentos, medicamentos e outros.

Diante exposto, as oficinas perderam forças e acabaram. Hoje, a escola conta com o trabalho voluntário da Justiça Comunitária. Elas oferecem, uma vez por semana, oficinas de produção manual e arcam com todos os custos. As produções são vendidas na feira cultural da escola e o lucro vai para a pessoa que produziu o material. Ainda assim, somente um grupo bem reduzido participa desta proposta. A justiça comunitária também oferece momento de terapia em grupo, uma vez por semana, essa segue a mesma realidade das oficinas. 


\subsection{CONTEXTO HISTÓRICO DA EDUCAÇÃO ESPECIAL}

$\mathrm{Na}$ antiguidade, as pessoas que nasciam com qualquer tipo de deficiência ou síndrome eram vistas como um castigo divino em função de suposto pecado por algum ancestral ou por outro motivo sobrenatural. Dependendo da cultura local e momento histórico, as pessoas deficientes eram abandonadas em locais de isolamento, hospitais, igrejas, quando não eram sacrificados. Na Grécia antiga, as crianças que nasciam com anomalias eram deixados em lugares santos ou nas florestas. Na Idade Média, por causa do Cristianismo, os deficientes passaram a receber um olhar de caridade.

Mudança significativa ocorreu com o Renascimento que trouxe explicações científicas e se distanciavam das justificativas sobrenaturais voltadas ao castigo divino. Nesse contexto, o deficiente passou a ser visto como carente de reabilitação, proporcionado pela área de saúde e educação. A atenção institucionalizada para as pessoas com deficiência aconteceu no final do século XVIII. Nesse momento surgiu a necessidade de se separar os "anormais" dos "normais". Deu-se o advento da segregação e da descriminação nas instituições educacionais (cf. ARANHA, 2000; BUENO, 1999: CARVALHO, 1996). No início do século XIX, expande-se o espírito científico e de investigação, paralelamente ao surgimento de escolas especializadas para cegos. As pessoas tidas como loucas, e por isso reclusas, iniciam sua participação no campo social.

No Brasil, as necessidades especiais inicialmente foram acolhidas pelas instituições residenciais segregadoras, isto é, instituições de caridade ou filantrópicas que se dedicavam a atender as pessoas com deficiência. A primeira foi criada em 1854, pelo monarca D. Pedro II, no Rio de Janeiro, intitulada "Imperial Instituto dos Meninos Cegos". Em 1857 fundou-se o Instituto dos Surdos e Mudos, atualmente Instituto Nacional de Educação de Surdos (INES). Assim, gradativamente, foram aparecendo instituições destinadas a atender pessoas com necessidades especiais. Essa expansão se deu especialmente a partir da década de vinte do século passado. Deve-se ressaltar que inicialmente na rede pública de ensino, somente eram matriculados as pessoas com Déficit Intelectual, conhecida como antiga deficiência mental. Nos anos 60 com a concepção de "integração", a mudança foi intensa a começar pela criação de Centros de Reabilitação para todos os tipos de deficiência.

O conceito de integração surgiu com a visão de que as escolas comuns deveriam aceitar alunos com deficiência. Essa visão foi registrada na Lei de Diretrizes e Base da Educação Nacional (LDBEN) - Lei № 4.024/61 - que afirmava o compromisso do poder público com a Educação Especial. Em 1971, o Ministério da Educação, por meio da Lei № 5692/71 associou-se a visão tecnicista para atendimento aos deficientes, no espaço escolar. Em 1975, aprovou-se a "Declaração dos Direitos das Pessoas Deficientes" em consonância a Constituição Brasileira estabelece que: 
O dever do Estado com a educação será efetivada mediante a garantia de atendimento educacional especializado aos portadores de deficiência, preferencialmente, na rede de ensino: Consta-se no novo ordenamento jurídico a preocupação com a integração (BRASIL, 1998, art. 208, inciso III).

A Coordenadoria Nacional para Integração da Pessoa Portadora de Deficiência (CORDE), órgão do Ministério da Justiça, passa a ser responsável pela integração da pessoa com deficiência. Nesse período, os deficientes passaram a ser conhecidos como pessoas portadoras de deficiência. Em 1989, a LDB com a Lei № 7.853, de 24 de outubro de 1986 apoiou a integração social das pessoas com deficiência. A Política Nacional de Educação Especial diz que:

\begin{abstract}
Integração é um processo dinâmico de participação das pessoas num contexto relacional, legitimando sua interação nos grupos sociais. A integração implica reciprocidade (...). Integração escolar - Processo gradual e dinâmico que pode tomar distintas formas de acordo com a necessidade e habilidade dos alunos. A integração educativa escolar refere-se ao processo de educar-ensinar, no mesmo grupo, a criança com ou sem necessidades educativas especiais, durante uma parte ou na totalidade do tempo de permanência na escola. (BRASIL, 1994, p.18).
\end{abstract}

O Brasil nos anos 90 adota as considerações que foram registradas na Conferência Mundial sobre Educação para Todos, as quais satisfazem as necessidades básicas de aprendizagem estabelecidas em Jomtiem - Tailândia, quando fez a opção pela construção de um sistema educacional inclusivo. A partir da discussão sobre a Política Nacional de Educação Especial em 1994, difunde-se o conceito de "educação inclusiva", aqui apresentada por Mantoan (1997, p.121):

A noção de inclusão institui a inserção de forma mais radical, completa e sistemática. $\mathrm{O}$ conceito se refere à vida social e educativa e todos os alunos devem ser incluídos nas escolas regulares e não somente colocadas na "corrente principal". A meta principal da inclusão é não deixar ninguém no exterior do ensino regular (...). A inclusão causa uma mudança de perspectiva educacional (...).

De modo geral e resumido, o caminho da integração para a inclusão no que se refere ao aluno com deficiência mental é que na integração quem sofre as transformações é o aluno, pois deve se adaptar ao novo meio. Já na inclusão, o meio deve transformar-se e adaptar-se para receber o aluno especial, primando pelo seu sucesso, nas palavras de González (2002, p.101):

(...) a escola compreensiva, que atende a diversidade, não da ênfase aos instrumentos didáticos, mas a mudança dos professores que se estende a 
escola, como instituições que devem aglutinar as convicções sociais, culturais e pedagógicas de todos os membros da comunidade educativa.

Ainda no ano 1994, o Brasil mostrou consonância com a Declaração de Salamanca Espanha - fruto da Conferência Mundial sobre as Necessidades Educativas Especiais. A Política Nacional de Educação Especial ressalta em seu teor a importância, as justificativas, os objetivos da educação inclusiva e sugestões de operacionalização. Ela registra que:

Os sistemas educativos devem ser projetados e os programas aplicados de modo que tenham em vista toda gama dessas diferentes características e necessidades; todas as crianças devem ter acesso ás escolas comuns que deverão integrá-las numa pedagogia centralizada na criança, capaz de atender a estas necessidades. (BRASIL, 1994, p.14)

No atual contexto Educacional, em relação ao processo de educação especial, o foco está na inclusão. Na integração, o aluno se adapta ao meio, na inclusão, o meio se adapta para melhor atender o aluno com deficiência.

A educação de Pessoas com deficiência tem os mesmos objetivos da educação de qualquer cidadão. Os Centros de Ensino Especiais (CEE) da SEEDF atendem alunos de zero a sem limite de idade para a terminalidade. A título de esclarecimento, a LDB no9394/96 traz, no capítulo V que trata da Educação Especial Art. 59, II, a possibilidade dessa terminalidade acadêmica, através de uma certificação de escolaridade chamada terminalidade específica. Segundo a Resolução 02/01 do CNE Conselho Nacional de Educação, que instituiu as DNEE Diretrizes Nacionais para Educação Especial:

\begin{abstract}
É facultado às instituições de ensino, esgotadas as possibilidades pontuadas nos Artigos 24 e 26 da LDBEN, viabilizar ao aluno com grave deficiência mental ou múltipla, que não apresentar resultados de escolarização previsto no Inciso I do Artigo 32 da mesma lei, terminalidade específica do Ensino Fundamental, por meio de certificação de conclusão de escolaridade, com histórico escolar que apresente, de forma descritiva, as competências desenvolvidas pelo educando bem como 0 encaminhamento devido para a Educação de Jovens e Adultos e para a Educação Profissional.
\end{abstract}

Ainda sobre terminalidade é necessário observar o que define o Regimento Escolar das Instituições Educacionais da Rede Pública de Ensino do Distrito Federal (2009, p.56):

Art. 119. É assegurada a terminalidade específica de Ensino Fundamental àqueles alunos que, pelas suas deficiências, não puderem atingir o nível exigido para sua conclusão, bem como a aceleração para concluírem em menor tempo o programa escolar aos alunos superdotados.

$\S 1^{\circ}$ A certificação de terminalidade específica deve ser fundamentada em avaliação pedagógica e registrada de forma descritiva, incluindo as competências alcançadas pelo aluno com grave deficiência intelectual e múltipla. 
$\S 2^{\circ}$ Os alunos com certificado de terminalidade específica do Ensino Fundamental podem ser encaminhados para cursos de Educação de Jovens e Adultos e de Educação Profissional, bem como para inserção no mundo do trabalho, seja competitivo ou protegido.

Com base na documentação legal, até o presente momento, os alunos matriculados no CEE, mesmo que não apresentem ganhos pedagógicos com o avançar da idade, não podem ser desvinculados dos Centros. Assim, essas instituições organizam outras propostas que possam favorecer e atender as necessidades de tais alunos. Preponderantemente, os alunos chegam ao CEE por três caminhos: (a) ao nascer, por diversos motivos a equipe médica percebe que a criança necessita de Educação Precoce e o encaminha ao CEE; (b) quando o pediatra diagnostica a deficiência na criança ou (c) na idade escolar, quando o aluno apresenta déficit de aprendizagem, inquietação em excesso e não acompanha a turma, então o professor regente solicita avaliação à Equipe de Apoio e Aprendizagem (EAA) que ao perceber indicativo de deficiência no aluno, solicita ao responsável a avaliação médica.

É importante lembrar que a integração das áreas de Educação e Saúde deveria ser uma constante neste processo de identificação de possíveis deficiências que são diagnosticadas na gestação ou após o nascimento. No contexto escolar, pode-se afirmar, com base na observação cotidiana, que são inúmeros os benefícios desse trabalho, isto é, os alunos devidamente diagnosticados apresentam maiores possibilidades de desenvolvimento das habilidades físicas, motoras e intelectuais quando identificados e encaminhados o mais cedo possível a Educação Precoce. Cabe explicar que nem sempre a deficiência ocorre ou pode ser diagnóstica na infância, surgindo em qualquer fase da vida em função de vários motivos entre eles: doenças, febres altas, acidentes, cirurgias, traumas, fraturas, convulsões e outros.

Em conformidade com o documento do CONAE (2010) pode-se afirmar que em relação ao papel do Estado, faz-se necessário a intersetoriedade no atendimento educacional especializado as crianças desde o nascimento aos três anos, fazendo o uso da intervenção precoce, para otimizar o processo de desenvolvimento e aprendizagem.

No entanto, deve-se ressaltar que em função de vários problemas que estão relacionados com as políticas públicas, observa-se que a integração entre esses profissionais precisa ser aperfeiçoada para que o diálogo a ser constituído proporcione a pessoa com deficiência e a sua família o devido atendimento que é assegurado pelas diversas leis, uma vez que "é dever do Estado a garantia do direito à educação de qualidade, estabelecido na Constituição Brasileira de 1988, na Lei de Diretrizes e Bases da Educação Nacional (LDB/1996) e no Plano Nacional de Educação (PNE 2001-2010)". 
Observa-se que os educandos da EJA do CEE 02 que tiveram a oportunidade de passar por todas as etapas de diagnóstico e encaminhamento médico, atendimento na EP, acompanhamento pela equipe multidisciplinar com profissionais da saúde e educação, apresentam melhores resultados e facilidades no que diz respeito à aquisição de novos conhecimentos. É importante afirmar que vários alunos são provenientes apenas do ambiente familiar e chega à escola com idade avançada, o que compromete o atendimento. Percebe-se que esse fator, em vários casos, está ligado a falta de informação da família, a vergonha de ter um filho (a) com deficiência, a falta de recursos, baixo poder aquisitivo entre outros.

De forma geral e à luz dos vários horizontes que a educação deseja alcançar, no contexto escolar, há espaço para as Pessoas com Deficiências (PD) que quando devidamente matriculadas na escola devem ser estimuladas a desenvolverem suas potencialidades em diversas áreas de ensino, de forma concreta, voltada para a realidade do educando, valorizando o conhecimento dos discentes, valorizando seus acertos de modo que aconteça a ampliação da autoestima e da segurança visando o pleno desenvolvimento do educando sem que este sofra alguma forma de preconceito ou discriminação.

A expressão "Educação Especial" remete-se automaticamente aos alunos rotulados excepcionais, sendo entendida como processo de segregação e atendimento educacional diferenciado do sistema educacional como um todo, entretanto não é este o direcionamento dado pelos PCNs (1999, p.21) - Adaptações Curriculares:

\begin{abstract}
Educação Especial - Modalidade da educação escolar. Processo educacional definido em proposta pedagógica, assegurando um conjunto de recursos e serviços educacionais especiais, organizados institucionalmente para apoiar, complementar e, em alguns casos, substituir os serviços educacionais comuns, de modo a garantir a educação escolar e promover o desenvolvimento das potencialidades dos educandos que apresentam necessidades educacionais especiais, em todas as etapas e modalidades da educação básica.
\end{abstract}

Além da definição acima, conta-se com conceito registrado no Documento elaborado pelo Grupo de Trabalho nomeado pela Portaria no 555/2007, prorrogada pela Portaria $n^{\circ}$ 948/2007, entregue ao Ministro da Educação em 07 de janeiro de 2008. POLÍTICA NACIONAL DE EDUCAÇÃO ESPECIAL NA PERSPECTIVA DA EDUCAÇÃO INCLUSIVA, onde declara a Educação Especial como:

(...) uma modalidade de ensino que perpassa todos os níveis, etapas e modalidades, realiza o atendimento educacional especializado, disponibiliza os serviços e recursos próprios desse atendimento e orienta os alunos e seus professores quanto a sua utilização nas turmas comuns do ensino regular. 
Destaca-se ainda as orientações sobre a deficiência mental/intelectual apresentado pela Secretaria de Educação do Distrito Federal por meio das Orientações Pedagógicas (2010, p. 22-23):

Segundo a atual American Association on Intellectual and Developmental Disabilities - AAIDD, deficiência intelectual/mental é a "incapacidade caracterizada por importantes limitações, tanto no funcionamento intelectual como no comportamento adaptativo, expressa nas habilidades adaptativas conceituais, sociais e práticas. Essa incapacidade tem início antes dos 18 anos de idade" (AAMR, 2006, p. 20).

O modelo teórico do Sistema 2002, proposto pela AAIDD, apresenta uma relação dinâmica entre o funcionamento do indivíduo, os apoios oferecidos e os contextos. Esse modelo abrange cinco dimensões principais: habilidades intelectuais (Dimensão I); comportamento adaptativo (Dimensão II); participação, interações, papéis sociais (Dimensão III); saúde e contexto (Dimensão V).

As habilidades intelectuais referem-se à inteligência, compreendida como uma habilidade mental geral, cuja aplicação dá-se por meio do raciocínio, do planejamento, da resolução de problemas, do pensamento abstrato, da compreensão de idéias complexas e da aprendizagem rápida, baseadas nas experiências da própria pessoa.

O comportamento adaptativo é a reunião das habilidades conceituais, sociais e práticas que foram aprendidas pelas pessoas e são colocadas em prática em seu cotidiano. Quanto à participação, interações e papéis sociais, observa-se que a participação e as interações podem ser verificadas pelo envolvimento da pessoa em atividades sociais cotidianas. Com relação à saúde, faz-se referência à saúde física e mental do indivíduo, definida pela Organização Mundial de Saúde - OMS como sendo um estado de bem-estar completo: físico, mental e social. Acrescenta-se que essa dimensão influencia o funcionamento humano nas demais dimensões. Por fim, apresenta-se o contexto - ambientes e cultura cuja representação é a descrição das condições interrelacionadas em que vivem as pessoas no seu cotidiano.

A deficiência intelectual/mental refere-se, portanto, a um estado particular de funcionamento intelectual iniciado na infância, apresenta característica multidimensional e é passível de responder positivamente aos apoios individualizados oferecidos à pessoa. Dessa forma, destaca-se que a avaliação da condição do estudante tem como finalidade a identificação $\mathrm{da}(\mathrm{s})$ necessidade(s) do estudante para o consequente direcionamento de atendimento(s).

Nesta perspectiva a Educação Especial busca melhor oportunizar proposta pedagógica para as pessoas com deficiência, excluindo as barreiras que causam a restrição e participação ativa e representativa em espaço escolar, assim construindo uma sociedade para cidadania e com respeito à diversidade. 


\subsection{INSTITUIÇÃO}

Nome: Centro de Ensino Especial 02 de Ceilândia

Endereço: QNO 12 Área Especial G

Instância institucional de decisão:

Governo: ( ) Estadual: ( ) Municipal ( ) DF

Secretaria de Educação: ( ) Estadual ( ) Municipal (X ) DF

Conselho de Educação: ( ) Estadual ( ) Municipal (X ) DF

Outros: Conselho Escolar do CEE 02

\subsection{PÚBLICO}

O projeto de intervenção local terá como foco os educandos com Déficit Intelectual da Educação de Jovens e Adultos do Centro de Ensino Especial 02 de Ceilândia. Para melhor compreender o termo déficit intelectual, adota-se o conceito utilizado pela American Association of Retardation (AAMR), registrada na Política Nacional de Educação Especial e demais documentos que seguiram a educação. Ela definiu deficiência mental (hoje entendido como deficiência intelectual) como:

(...) um funcionamento intelectual significativamente abaixo da média, coexistindo com limitações relativas a duas ou mais das seguintes áreas de habilidades adaptativas: comunicação, autocuidado, habilidades sociais, participação familiar e comunitária, autonomia, saúde e segurança, funcionalidade acadêmica, de lazer e de trabalho. (apud, BRASIL, 1994, p. 39).

A Política Nacional de Educação Especial na perspectiva da Educação Inclusiva do MEC/SEESP define os conceitos do público alvo na educação especial:

- deficiência - aqueles que têm impedimentos de longo prazo, de natureza física, mental, intelectual ou sensorial,que em interação com diversas barreiras podem ter restringida sua participação plena e efetiva na escola e na sociedade;

- transtornos globais de desenvolvimento - aqueles que apresentam alterações qualitativas das interações sociais recíprocas e na comunicação,um repertório de interesses e atividades restrito,estereotipado e repetitivo". Incluindo nesse grupo alunos com autismo,síndromes do espectro do autismo e psicose infantil;

- altas habilidades/superdotação - aqueles alunos "que demonstram potencial elevado em qualquer uma das seguintes área, isoladas ou combinadas: intelectual, acadêmica, liderança, psicomotricidade 
A Secretaria de Estado de Educação do Distrito Federal (SEEDF) busca assegurar o direito legal ao educando com deficiência por meio de medidas administrativas que proporcionam uma educação de qualidade e que corresponda com as necessidades dos mesmos.

É importante destacar que para definir a formação das turmas, utiliza o documento denominado Estratégia de Matrícula para a Rede Pública de Ensino do Distrito Federal (2010). Deve-se entender que:

\begin{abstract}
A Estratégia de Matrícula é o documento elaborado, anualmente, pela Subsecretaria de Gestão Pedagógica e Inclusão Educacional (SGPIE), subsidiada pela A Diretoria de Organização do Sistema de Ensino, de acordo com o Decreto №. 30.175 de 17 de março de 2009, em conformidade com o artigo ํo 123, parágrafo único, da Resolução ํo. 01/2009-CEDF, de 16/06/2009 e Regimento Interno da Secretaria de Estado de Educação do Distrito Federal, aprovado pelo Secretário de Estado de Educação do Distrito Federal, com o fito de normatizar o processo de matrícula na Rede Pública de Ensino do Distrito Federal, para o ano letivo subsequente.
\end{abstract}

Em regra, o CEE 02, segue as orientações da estratégia para a formação das turmas. Há situações em que surge a necessidade de ajustes, como exemplo pode-se citar a Educação de Jovens e Adultos ofertada em todos os Centros de Ensino do Distrito Federal, que adota uma metodologia adaptada para atingir os objetivos conforme as características dos educandos. Pode-se afirmar que no CEE 02 essa dinâmica é adotada com o intuito de oferecer uma educação de qualidade para os alunos da EJA, uma vez que cada educando possui características peculiares que solicitam uma organização educacional que respeite suas especificidades.

Desta forma, no CEE 02, a EJA para discentes com DI corresponde a duas turmas, totalizando 52 (cinqüenta e dois) alunos, sendo 28 no turno matutino e 24 no vespertino. $O$ grupo é bem homogêneo entre gênero. As turmas são compostas por educandos entre 15 à 31 anos. Atualmente a estratégia de matrícula vigente registra que as turmas devem ser formadas por alunos a partir dos 15 anos e não conta com idade fim, sendo respeitado o mínimo de 18 alunos e o máximo de 32 por turma.

No que diz respeito às condições de atendimento pedagógico em sala de aula no CEE 02, os discentes são contemplados com currículo multidisciplinar condizente a jornada de 5 horas aula, onde a proposta pedagógica visa oportunizar o desenvolvimento das habilidades intelectuais, motoras, afetivas, sociais e profissionais.

Os atendimentos de Educação Física acontecem duas por semana. Educação Artística e Atividades da Sala de Leitura são desenvolvidas respectivamente uma vez por semana. As atividades acadêmicas são realizadas com a professora regente todos os dias e 
correspondente às $2 \mathrm{~h}$ e $30 \mathrm{~min}$ diária. Além da regente, o aluno é atendido pela professora das Oficinas Pedagógicas (OP), que tem por objetivo a profissionalização.

Para o enriquecimento do currículo e com o intuito de valorizar a proposta de inclusão, o Centro realiza inúmeras atividades extraclasse com o objetivo de inserir os educandos nos diversos contextos sociais, educacionais e culturais, a saber: cinema, shopping, parques, museus, clubes, feiras, zoológico entre outros de modo que sejam adquiridas as habilidades de socialização e integração.

Destaca-se que para a realização das atividades escolares internas e externas faz-se necessário adaptações curriculares de pequeno e grande porte, essas contribuem para acesso, compreensão e acomodação das ações promovidas ao corpo discente.

As adaptações curriculares propostas pelo MEC/SEF/SEESP a Educação Especial visam promover o desenvolvimento e a aprendizagem dos alunos que apresentam necessidades educacionais especiais, tendo como referência a elaboração do projeto pedagógico e a implementação de práticas inclusivas no sistema escolar.

A Educação Especial é concebida como modalidade de educação escolar complementar, necessária aos alunos com deficiência para alcançarem os fins da educação geral. Este viés permeia as proposições contidas no documento lançado pelo MEC, na orientação da ação pedagógica dos educadores quanto às adaptações curriculares, que visam à inserção no sistema escolar de alunos com deficiências física, sensorial, mental, altas habilidades, condutas típicas e outras peculiaridades. Tal viés é reforçado na afirmação a seguir:

\footnotetext{
"A análise de diversas pesquisas brasileiras identifica tendências que evitam considerar a educação especial como um subsistema à parte e reforçam o seu caráter interativo na educação geral. Sua ação transversal permeia todos os níveis - educação infantil, ensino fundamental, ensino médio e educação superior, bem como as demais modalidades- educação de jovens e adultos e educação profissional".(Parâmetros Curriculares Nacionais: Adaptações Curriculares MEC/SEF/SEESP 1998: 21)
}

De modo geral, pode-se falar em dois tipos de adaptações curriculares, as chamadas adaptações de acessibilidade ao currículo e as adaptações pedagógicas (SME-RJ, 1996). As primeiras se referem à eliminação de barreiras arquitetônicas e metodológicas, sendo pré-requisito para que o aluno possa freqüentar a escola regular com autonomia, participando das atividades acadêmicas propostas para os demais. Estas incluem as "condições físicas, materiais e de comunicação". As adaptações curriculares, propriamente ditas, são modificações no planejamento, nos objetivos, nas atividades, nas formas de avaliação, enfim, em aspectos do currículo ou nele como um todo para acomodá-lo aos alunos com deficiência. 
A instituição escolar deve apresentar compromisso com 0 acesso ao saber historicamente acumulado, como consta da introdução aos Parâmetros Curriculares Nacionais (PCNs):

Isso requer que a escola seja um espaço de formação e informação, em que a aprendizagem de conteúdos deve necessariamente favorecer a inserção do aluno no dia-a-dia das questões sociais marcantes e em um universo cultural maior. A formação escolar deve propiciar o desenvolvimento de capacidades, de modo a favorecer a compreensão e a intervenção nos fenômenos sociais e culturais, assim como possibilitar aos alunos usufruir as manifestações culturais nacionais e universais. (MEC, 1997, p.45)

Adequar currículo para todos os alunos é uma tarefa extremamente complexa, mas é uma necessidade que se impõe. Segundo Carvalho (2008) "as Adaptações Curriculares devem ser entendidas como um conjunto de estratégias que permitam flexibilizar os conteúdos do currículo de modo a permitir a todos estabelecer relações com o saber."

As finalidades das Adaptações Curriculares são, dentre outras, conseguir a maior participação dos alunos deficientes em atividades desenvolvidas no projeto curricular da escola e na programação da sala de aula.

Em suas considerações sobre a Adaptação Curricular, o Projeto Escola Viva (MEC/SEE, 2000), considera a importância de refletir sobre as peculiaridades de cada aluno. São suas palavras:

Ao refletir sobre tudo isso, enxergamos com clareza que cada aluno tem peculiaridades específicas e especiais, e que para atendê-las temos, às vezes, que fazer ajustes e adaptações no currículo regularmente proposto para os diferentes níveis da escolaridade, de forma a garantir as condições (respostas educacionais) que Ihes são necessárias para acessar o conhecimento disponível como qualquer um de seus demais colegas. (MEC/ SEE, 2000, p.7)

Nota-se ainda, que as Diretrizes Pedagógicas da Secretaria de Estado de Educação do Distrito Federal (2009/2013), apresentam orientações pertinentes em relação às adequações curriculares e as ações docentes fundamentadas em critérios que definem:

- o que o aluno deve aprender;

- como e quando aprender;

- que formas de organização de ensino são mais eficientes para o processo de aprendizagem;

- como e quando avaliar.

As Diretrizes Pedagógicas solicita as escolas a construção do Projeto Político Pedagógico (PPP) voltado para as necessidades dos educandos, onde haja adequações e adaptações na matriz curricular de modo que o currículo ofertado ao aluno com deficiência 
seja compatível com seu contexto. Conforme as Diretrizes Pedagógicas (2009/2013, p.78), percebe-se as seguintes medidas nas adequações de acesso ao currículo:

- Criar condições físicas, ambientais e materiais para o aluno na instituição educacional de atendimento;

- Propiciar os melhores níveis de comunicação e interação com as pessoas com as quais convive na comunidade escolar;

- Favorecer a participação nas atividades escolares;

- Disponibilizar mobiliário específico necessário;

- Fornecer ou adquirir os equipamentos e os recursos materiais específicos necessários;

- Adaptar materiais de uso comum em sala de aula; e

- Adotar sistemas de comunicação alternativos para os alunos impedidos de comunicação oral (no processo de ensino e de aprendizagem e na avaliação).

Em consonância com o documento acima citado, pode-se afirmar que essas adequações curriculares enfocam recursos para fortalecer o ato de ensinar e avaliar, por meio da valorização do educando e o desenvolvimento de suas habilidades considerando aspectos como a temporalidade, os conteúdos e os objetivos.

Alicerçado, ainda, nas Diretrizes Pedagógicas é admissível descrever que as adequações curriculares realizadas no CEE 02 são de pequeno e grande porte, uma vez que sempre é observado o diagnóstico do educando de modo que as adequações planejadas e executadas estejam direcionadas para o potencial do corpo discente.

\subsection{PERÍODO DE EXECUÇÃO}

- Início: o ano letivo de 2009

- Término: projeto contínuo 


\subsection{PARCEIROS}

- Equipe Gestora, Conselho Escolar e Corpo Docente: a parceria desta tríade se dar no sentido oportunizar no espaço escolar condições pedagógicas e práticas que envolvam os educandos com o mundo do trabalho, assim estes profissionais devem registrar no PPP tal meta e propiciar ações para a efetiva realização de tal meta.

- Diretoria Regional de Ensino: apóio para viabilizar e oficializar as parcerias e na autorização de abertura de carências dos docentes que atuarão em oficinas pedagógicas e docente do serviço de orientação para o trabalho.

- Centro comunitário do Setor "O": ofertar de cursos ao educandos da EJA/ DI do CEE 02 de Ceilândia

- Escola Técnica De Ceilândia: Oferta de cursos aos educandos.

- Lions Club: Oferta de materiais e Cursos aos discentes.

- Comércio Local: Doação de produtos e recursos para confecção dos materiais necessários as oficinas pedagógicas.

- EMATER: Disponibilização do galpão das aulas de práticas agrícolas para realização de encontros e cursos que Lions Club irá oferecer.

- Feira de Ceilândia: Venda dos materiais produzidos pelos educandos (EJA/DI) 


\section{AMBIENTE INSTITUCIONAL}

O Centro de Ensino Especial (CEE) 02 de Ceilândia, está localizado na RA IX do Distrito Federal e surgiu em decorrência da demanda apresentada pelo Centro de Ensino Especial 01, localizado no Setor P. Sul, também em Ceilândia, que até final de 1998 era o único Centro de Educação Especial desta cidade. A partir de 1994, vários profissionais dedicaram esforços para abertura de mais um Centro de Educação Especial ${ }^{3}$ na Ceilândia.

No cenário político do Distrito Federal entre 1995-1999, foi criado o "Orçamento Participativo". Ele possibilitou as negociações favorecedoras para a construção de mais um Centro. Após inúmeras reuniões com a comunidade escolar foram oferecidos dois terrenos, onde o grupo que estava a frente do orçamento participativo escolheu o terreno onde está localizado o Centro de Ensino Especial 02 (QNO 12 - Área Especial G - Setor "O" Ceilândia).

Em 17 de dezembro de 1998 houve a inauguração. Ela contou com a presença de toda a comunidade escolar e das autoridades: Governador e Vice-governadora, Secretário de Obras, Secretário de Educação, Diretor Executivo da Fundação Educacional do Distrito Federal e o Administrador Regional da Ceilândia. Apesar do ato solene de inauguração, somente aos 15 dias do mês de janeiro de 1999 as obras estavam concluídas e o Centro contava apenas com a estrutura física

É importante destacar que os primeiros atendimentos aconteceram pelo da equipe gestora, do corpo técnico, do administrativo, de conservação e dos docentes. Estes foram em busca de todos os recursos inerentes ao bom funcionamento e andamento da prática pedagógica, isto é; os profissionais, praticamente iniciaram o ano letivo com a coragem de trabalhar, tendo em vista que não contavam com os recursos materiais necessários.

O CEE 02 Ceilândia investe na educação das pessoas com necessidades educativas especiais, proporcionando-lhes a oportunidade de ultrapassar barreiras econômicas, sociais e culturais, com intuito de contribuir pela qualidade de vida e valorização do ser humano, vivência e exercício pleno da cidadania.

Segundo dados apresentados no Projeto Político Pedagógico (PPP) do CEE 02 do ano de 2009, os alunos matriculados no CEE 02 são aqueles que após avaliação e estudos de caso não apresentaram condições, em seu quadro geral, a serem incluídos na rede regular de ensino. Alguns são oriundos do ensino regular, resultado de condutas/orientações educacionais as quais entenderam que estes apresentam idade além do permitido para permanecer nas classes regulares e desempenho acadêmico e social incompatível com o exigido nas propostas educacionais, sendo, portanto, encaminhados ao CEE com intuito de

\footnotetext{
${ }^{3}$ Idem nota 1.
} 
receberem atendimento educacional especializado, adaptado e condizente a estes educandos. Ainda há os alunos do atendimento complementar, que recebem no Centro um apoio educacional que favoreça o progresso dos mesmos na rede regular de ensino.

Na modalidade de educação especial, o CEE 02 oferece:

- Programa de Educação Precoce (PEP): recebe educandos com idade de 0 à 3 anos. Estes são encaminhados a escola por intermédio da área médica que após vários exames comprovam um quadro de risco as crianças (prematuro, anoxiado, filhos de mães hipertensas e outras) ou geralmente, crianças diagnosticadas com paralisia cerebral, transtorno Global do Desenvolvimento e outras síndromes. Entende-se por síndrome um grupo de sintomas que ocorrem em conjunto, caracterizando uma determinada doença.

- Deficiência Múltiplas (DMu): turmas formadas por alunos acima de 04 anos de idade, com duas ou mais deficiência que interferem no desenvolvimento global. São estudantes acima 4 anos de idade. Sua composição de 1 à 3 alunos. $O$ foco destes atendimentos é o currículo funcional que propõe ao aluno $\mathrm{DMu}$ oportunidades educacionais adequadas ás suas características específicas, buscando o desenvolvimento máximo de suas potencialidades na conquista da independência e autonomia.

- Déficit Intelectual (DI): são atendidos em classes de 04 a 08 alunos por turma. O funcionamento desta área corresponde ao da educação infantil/currículo adaptado. Nesta área estão os alunos com maiores perspectivas de inclusão.

- Transtorno Global do Desenvolvimento (TGD): contemplam em seu atendimento alunos que apresentam comportamento típico de síndromes, quadros psicológicos e neurológicos que ocasionam atraso no desenvolvimento e prejuízo no relacionamento social, requerendo assim atendimento educacional especializado. Os alunos, dadas as suas características específicas, são atendidos individualmente (quando justificado tal necessidade junto a Gerência de Educação Especial), em turmas formadas por dois alunos de 04 à 14 anos e ainda, em turma de rodízio, formada de 3 a 5 alunos com idade acima de 14 anos. 
- Oficinas Pedagógicas (OP): turma formada de 12 à 16 alunos acima de 14 anos que não apresentam ganhos pedagógicos. Essa área visa a semiprofissionalização por meio de atividades manuais na produção de bijuterias, tapetes, quadros e caixas.

- Educação de Jovens e Adultos (EJA): alunos acima de quinze anos, atendidos em turmas de 12 à 32. Estes recebem atendimento adaptado para alfabetização de jovens e adultos da educação especial. O atendimento acontece cinco vezes por semana com carga horária de cinco horas diárias. Os alunos desta área recebem atendimento em oficina do "Papel reciclado". Essa oficina é oferecida exclusivamente aos alunos da EJA.

- Atendimento Complementar (AC): apóia o processo inclusivo na oferta atividades de artes, leitura, informática, horta e educação física aos alunos pertencentes à Região Norte de Ceilândia, num total de140 educandos com diagnósticos variados que dificultam a aprendizagem.

Todos os alunos do Centro são contemplados com aulas de educação física, artes e leitura, além da proposta pedagógica desenvolvida pelo regente. Os atendimentos são construídos com base nas orientações educacionais vigentes e no conhecimento técnico dos professores para atender às especificidades dos estudantes, assim, aplicamos o que diz os PCNs - Parâmetros Curriculares Nacionais:

Educação Especial - Modalidade da educação escolar. Processo educacional definido em proposta pedagógica, assegurando um conjunto de recursos e serviços educacionais especiais, organizados institucionalmente para apoiar, complementar, suplementar e, em alguns casos, subsistir os serviços educacionais comuns, de modo a garantir a educação escolar e promover o desenvolvimento das potencialidades dos educandos que apresentam necessidades educativas especiais da educação básica. (BRASIL, 1999, p.21).

Os alunos atendidos neste Centro são residentes na Ceilândia Norte, Setor "O", Expansão do Setor "O”, Condômino Privê, Águas Lindas de Goiás e novas áreas residenciais da Ceilândia (área de chácaras).

A comunidade escolar (discentes e familiares), de forma generalizada e no campo econômico, é carente (adotamos como carente as famílias que apresentam renda per capita de 1/2 salário mínimo. A presença dos responsáveis se restringe a reuniões pedagógicas e festas. Não há participação efetiva em todos os momentos propostos pela escola. 
Dada às carências (social e financeira) e especificidades destes alunos, há a necessidade de diversos recursos materiais e profissionais capacitados com intuito de melhor atender esses discentes. O ideal seria a parceria da SEEDF com profissionais das áreas de fonoaudiólogo, fisioterapeuta, psicólogo, assistente social, médicos (clínico geral, pediatras, neurologistas, oftalmologistas e odontologista).

Quanto à parte física do CEE 02, apesar de possuir uma área ampla, o número de salas ainda é insuficiente para a nossa proposta pedagógica e para o número de alunos matriculados. A piscina externa, um dos melhores recursos para estimulação dos alunos com déficit motor e sensorial, encontra-se desativada desde 2003, devido a não funcionabilidade estrutural e danos provocados por depredação de pessoas da comunidade que invadiram a escola.

Em função das limitações de nossa comunidade, convivemos constantemente com problemáticas que vão além das nossas responsabilidades pedagógicas. Temos conhecimento de até aonde vai a nossa atribuição funcional/profissional, entretanto é impossível fecharmos os olhos as necessidades básicas pelas quais a maioria dos nossos discentes está inserido. Assim, somos levados, por questão de humanidade, a nos envolver em papéis que não são de nossa competência como servidores da educação, mas de responsabilidade como cidadãos que valorizam a integridade do ser humano.

A identidade de cada escola é construída com base nas demandas e necessidades onde está inserida, sendo interferida pela a qualidade de quem a faz acontecer, isso lhe atribuem singularidade Neste ponto é coerente que a gestão escolar esteja alicerçada na concepção de Gestão Democrática (GD).

Vale esclarecer que a GD pressupõe descentralização do poder para a instância da unidade local que aperfeiçoa ações comunicativas entre os membros da comunidade escolar, configurando em estratégias favoráveis a prática escolar participativa (KRAWCZYK, 1999, citado por NAVARRO, 2004).

Assim a Equipe Gestora (EG) deve reconhecer que "na escola todos têm contribuições e saberes para compartilhar e que todos os processos realizados nos espaço da escola são vivências formativas e cidadãs (VIEIRA, 2009).

No fortalecimento da educação de qualidade seguida pela participação coletiva e democrática, surge a Lei 4.036 de 25/07/2007, e regulamentada pelo Decreto 29.207, de 26/06/2008 que estabelece o CE como representação da comunidade, assumindo função deliberativa, consultiva, fiscal e mobilizadora (Art. 1 do Dec. 29.207/2008).

Seguindo essa linha de pensamento a Equipe Gestora (EG) e Conselho Escolar (CE) devem elaborar Projeto Político Pedagógico (PPP) como instrumento imprescindível na transformação do espaço escolar, articulando ações para sanar as problemáticas e falhas e privilegiar ás praticas que indicam sucesso. 
Em posse da monografia: Projeto Político Pedagógico, Equipe Gestora e Conselho Escolar do Centro de Ensino Especial 02 de Ceilândia, apresentado a Universidade de Brasília em 15 de agosto de 2009, foi percebido que esta instituição educacional privilegia a participação coletiva a qual é considerada como um compromisso integrado às responsabilidades sociais, estando em consonância com o que diz Luck (2005) em relação à gestão escolar e a promoção pela participação de todos:

- Melhorar a qualidade pedagógica do processo educacional das escolas;

- Garantir ao currículo escolar maior sentido de realidade e atualidade;

- Aumentar o profissionalismo dos professores;

- Combater o isolamento físico, administrativo e profissional.

- Motivar o apoio das comunidades escolar e local ás escolas;

- Desenvolver objetivos comuns na comunidade escolar.

De acordo com Cury (2005, p.3) "a gestão democrática da educação é, ao mesmo tempo, transparência e impessoalidade, autonomia e participação, liderança e trabalho coletivo, representatividade e competência." Neste sentido e conforme o trabalho acima citado, o CEE 02 tem a cultura da discussão do PPP, favorece e estimula o papel do Conselho Escolar na dinâmica educativa e "entende a educação como espaço polissêmico, multidimensional e integrador da diversidade, no qual diversos sentidos e significados são construídos diariamente." (PPP. p. 47) 


\section{JUSTIFICATIVA E CARACTERIZAÇÃO DO PROBLEMA}

A inclusão dos educandos com déficit intelectual no mundo de trabalho tem se tornado um grande desafio nos últimos tempos. Para tanto, é necessário que as instituições públicas e privadas reconheçam seu papel, oferecendo políticas e programas socioeducativos responsáveis em proporcionar oportunidades e igualdades de condições para que os deficientes intelectuais conquistem seu espaço no mundo de trabalho.

O processo de desenvolvimento social está pautado na constituição de formação oferecida em diversos níveis de ensino, na valorização da diversidade cultural, na troca de informação e no empenho das instituições formadoras do conhecimento, visando a preparação adequada do cidadão para participar com equidade das ações realizadas na sociedade da qual faz parte. Assim, identifica-se como objeto deste projeto o Educando com Déficit Intelectual em EJA no contexto: mundo do trabalho. É importante destacar que existe diferença entre mundo do trabalho e mercado de trabalho.

Nota-se que há diferenças significativas em relação aos conceitos de mundo do trabalho e mercado de trabalho. Observa-se que o primeiro abarca um contexto amplo, isto é, o trabalho deve ser executado de forma que as habilidades resultam na utilização das habilidades intelectuais que reforçam o aperfeiçoamento e qualificação dos diversos profissionais. Enquanto que mercado de trabalho contempla a intenção dos cidadãos na busca pelo emprego, sendo uma visão capitalista. Destaca-se ainda que muitas vezes o mercado de trabalho tem sido bastante concorrido, essa experiência muitas vezes impede que algumas pessoas sejam inseridas neste meio.

Nesse sentido, pode-se afirmar que o trabalho informal pode contribuir para que todos tenham possibilidade de participar do mundo do trabalho, um exemplo seria as cooperativas. As cooperativas são formadas pela associação de pessoas autônomas que se unem para responder as necessidades econômicas de forma coletiva e democrática.

Nesta proposta de inovação e busca de elementos que tornem possível o exercício da cidadania e inclusão por meio da formação no ambiente escolar, acadêmico e profissionalizante surge alguns questionamentos: como a escola tem efetivado suas ações juntamente com as demais instituições para favorecer a integração do educando no mundo de trabalho? Por que o educando da EJA com déficit intelectual não é contemplado no mercado de trabalho? Diante o exposto elencam-se sugestões que venham favorecer a inserção do aluno da EJA com déficit intelectual no mundo do trabalho. 


\subsection{RELATO DE EXPERIÊNCIA}

Ao iniciar o processo de elaboração do projeto de intervenção local, conforme orientação apresentada foi utilizada a experiência vivenciada pela professora Maria Helena no segundo semestre letivo do ano de 2009, com o acompanhamento dos demais envolvidos no trabalho. Nesse ínterim, foi possível perceber que são várias as barreiras que a escola precisa vencer para inserir o educando no mundo do trabalho.

No ano letivo de 2008, foi implantado no Centro de Ensino Especial no 02, localizado na Região Administrativa de Ceilândia, a modalidade de Educação de Jovens e Adultos/1ํㅜㄴ segmento. As turmas foram criadas para atender as muitas reivindicações de pais que tinham filhos matriculados nas Oficinas Pedagógicas e conseqüentemente perderam a parte acadêmica mesmo apresentando condições de avanços. Quando o aluno completava 15 anos eram encaminhados para as oficinas semiprofissionalizantes de acordo com o perfil e habilidades manuais, ficando eliminados das classes de alfabetização.

Com a implantação da EJA/especial na escola, os pais que já se mostravam desanimados, com vontade de desistir de tudo, se encheram de esperança e começaram a fazer novos planos para o futuro dos filhos. Viram nas novas turmas grandes possibilidades de mudanças e realização dos filhos, além de uma inclusão sem distâncias e preconceitos.

Os alunos iniciaram aquele ano com muita vontade de aprender e conquistar seu espaço na sociedade por meio da inclusão social. Muito eufóricos e ao mesmo tempo ansiosos pela possibilidade de trabalhar, ter independência financeira e sentirem verdadeiros cidadãos, constantemente desabafavam:

Aluno A: "Não vejo a hora de trabalhar, receber o meu salário para comprar minhas coisas". Aluno B: "Quero poder trabalhar, ter uma profissão, fazer uma faculdade de psicologia e tirar a minha carteira de habilitação".

Aluno C: "Não quero depender do dinheiro da minha mãe. Com o meu salário, vou poder fazer compras e ter roupas e sapatos novos".

A angústia dos alunos foi compartilhada com seus professores que resolveram tomar algumas iniciativas a fim de reduzir distâncias e promover a tão sonhada inclusão social.

Conforme documento orientador da Secretaria de Estado de Educação, o aluno só é encaminhado para as classes inclusivas até os 14 anos, salvo exceção quando se tratar de aluno da EJA que vem especificação de idade. É importante ressaltar que a idade cronológica muitas vezes não corresponde com a idade intelectual do educando, fazendo com que em alguns casos o educando não seja beneficiado com a proposta da inclusão escolar. No entanto, ao continuar sendo atendido no Centro de Ensino, este aluno deverá continuar recebendo a formação adequada e com as devidas adaptações curriculares de 
maneira que tenham a possibilidade de serem inseridos em todos os âmbitos da sociedade inclusive no mundo de trabalho.

Focados na inclusão social, foi feito um levantamento dos alunos com perfil que atendessem às necessidades e exigências do mercado. Como na escola ainda não funcionava o SOT (Serviço de orientação para o trabalho), os regentes das turmas com o apoio do coordenador e da direção, foram em busca de parcerias porque entenderam que não se pode incluir sem uma devida qualificação.

Ainda no mesmo ano (2008), as coordenadoras da Diretoria de Ensino Especial responsáveis pelas turmas de EJA/especial, fizeram contatos com a coordenadora da escola, informando da disponibilidade de cursos profissionalizantes para os alunos matriculados na EJA.

O contato deixou todos muito esperançosos tanto alunos quanto professores. Houve orientação para acompanhar o aluno e suas famílias na agencia do primeiro emprego mais próxima de suas residências para realizar inscrições em alguns cursos disponíveis, respeitando critérios básicos de leitura, escrita, cálculos e raciocínio. Para a realização da inscrição, foi exigida ainda que o aluno portasse documentos pessoais como identidade, CPF, carteira de trabalho e inscrição no PIS. Os que não tinham, as famílias se prontificaram a retirar para concluir a inscrição com sucesso. Todos saíram dali cheios de expectativas, ansiedade e sonho pela possibilidade de transformar a realidade atual. Dias se passaram e nenhuma notícia, nem resposta foi quando os coordenadores receberam a resposta negativa, ou seja, os alunos não foram selecionados. Coordenadores e o corpo docente ficaram sem entender porque os alunos não foram contemplados com as vagas que foram ofertadas mesmo, atendendo as exigências solicitadas. Diante do descaso, muitos desanimaram e questionaram o objetivo de estarem ali. Alguns apresentaram mudança de comportamento, depressão. Foi solicitada a ajuda da equipe multidisciplinar para orientação aos alunos e suas famílias.

Como motivar os alunos diante de tantas barreiras? O objetivo central do professor além de alfabetizar é mostrar para esse aluno que existem inúmeras profissões e um mercado lá fora para que eles possam lutar por uma vaga.

O trabalho dos educadores é persistente, ou seja, deve ser pautado na conquista de novos saberes e na aquisição de conhecimentos contínuos de modo que o processo de inclusão, mesmo que demorado, aconteça para esses educados. Nessa expectativa podese afirmar que alguns meses se passaram até receber novamente o contato com a Diretoria de Ensino Especial/EJA Especial procurou a escola, a fim de selecionar alunos para participar de cursos no SENAC e encaminhá-los para estágio e colocação no mercado. Porém a exigência era que os alunos tivessem autonomia para se deslocarem de suas 
residências com destino a unidade do Plano Piloto sem acompanhantes. Como era uma situação nova, os pais ficaram com medo de levar a idéia adiante.

Diante de tantas dificuldades encontradas para promover a inclusão social ou no mundo do trabalho dos alunos com déficit intelectual, matriculados nas turmas de EJA, os professores solicitaram orientação e apoio da Equipe psicopedagógica da escola, essa buscou parceria do Centro de Educação Profissional, o qual fica localizado na Região Administrativa de Ceilândia. Os cursos foram disponibilizados de acordo com o perfil dos alunos, porém, o diretor do CEP Ceilândia fez a exigência de os alunos participassem dos cursos acompanhados da presença do professor regente. Em meio a tantos "nãos", finalmente uma porta se abriu e devolveu aos alunos a auto-estima e a esperança, eles começaram a participar do curso de garçom e corte e costura com a presença da professora regente do CEE 02.

Antes de fechar a parceria com o centro de capacitação, professores solicitaram a equipe de apoio que realizasse um trabalho de sensibilização com as famílias, pois, embora se tratasse de uma ação em que todos ganham, percebe-se que falar de independência para um pai que tem um filho com necessidades especiais não parece ser uma tarefa fácil. Mesmo cientes dos inúmeros benefícios que tais ações possam trazer para todos, muitas famílias mostram-se inseguras diante do novo, temem que os filhos sofram humilhações, sejam expostos ou passem por qualquer tipo de constrangimento.

O maior medo, no entanto, é que os filhos se percam ao se deslocarem para locais de cursos e empregos e não consigam retornar para as suas residências. Neste caso, as maiores barreiras começam dentro de casa, quando as famílias recuam para proteger os filhos e em outras situações para não perderem o benefício que na maioria das vezes, transforma-se na principal renda familiar. É importante mencionar que o Benefício de Prestação Continuada (BPC) é um benefício do Ministério do Desenvolvimento Social e Combate à Fome que atende idosos e portadores de deficiência, incapacitados para a vida independente e para o trabalho. O BPC garante um salário mínimo mensal à pessoa idosa e ao portador de deficiência incapacitado para a vida independente e para o trabalho, ambos impossibilitados de prover sua manutenção ou tê-la provida por sua família. Todos os idosos (com 65 anos ou mais) e os portadores de deficiência que se encontram nesta situação têm direito ao benefício. Basta comprovarem que a renda familiar per capita é inferior a $25 \%$ do salário mínimo. O direito Ihes é garantido pela Lei Orgânica da Assistência Social, a LOAS. Ressalta-se que muitas vezes em função do BPC a família resiste em aceitar que o educando seja inserido no mundo do trabalho, pois ao começar a trabalhar ele perde esse beneficio. 
Após várias reuniões, muitos entenderam que o objetivo do trabalho é garantir os direitos dos próprios filhos, que são cidadãos. Dessa forma, acabaram apoiando os projetos da escola e acompanhando os filhos nos locais de curso e inclusive, matriculando-se para incentivá-los. No segundo semestre do ano letivo de 2009, alguns alunos participaram dos cursos de garçom e corte costura ofertados pelo CEP. Os cursos foram adaptados para atender individualmente cada um segundo o seu perfil. Concluíram com sucesso, mas, não foram encaminhados para o trabalho, pois não correspondiam ao desejado.

\section{OBJETIVOS}

\subsection{Objetivo Geral}

Evidenciar os caminhos para que os estudantes de EJA com deficiência intelectual (DI) possam ser inseridos no mundo do trabalho de forma representativa e efetiva.

\subsection{Objetivos Específicos}

- Identificar os espaços de apoio que promovam a inserção do estudante de EJA/DI no mundo do trabalho;

- Buscar recursos no espaço escolar que possibilitem a inserção no mundo de trabalho para os estudantes da EJA/DI. 


\section{ABORDAGEM DA LITERATURA}

\subsection{A Educação de Jovens e Adultos no Brasil}

A Educação de Jovens e Adultos no Brasil registra avanços e benefícios acrescidos a esta modalidade de educação que vem possibilitando as garantias legais estabelecidas na Constituição em seus diversos artigos sobre os direitos e deveres do cidadão. Conforme o relato histórico é importante destacar:

\section{- 1964 - 1985 - Regime Militar: contexto educacional}

* O processo de ensino em todas as áreas da educação brasileira e mantida pelos comandantes das Forças Armadas, esse período deixa marcas profundas na história do país;

* Os direitos do cidadão são banidos;

* Interferência na vida das pessoas de todas as idades, assim como na força laboral ativa e no mercado de mão de obra de reserva ou força de trabalho potencial.

* Intervenção nas Universidades brasileiras.

* O Conselho Federal de Educação - CFE - nomeia reitores militares para diversas instituições de ensino tentando assegurar o controle militar;

- Na Universidade de Brasília - UnB ocorre a invasão por tropas, destituindo o reitor Anísio Teixeira, prendendo professores e alunos suspeitos de serem subversivos.

- Educadores como Anísio Teixeira, Fernando de Azevedo, Paulo Freire, Durmeval Trigueiro e muitos outros, foram calados ou perseguidos em função de posicionamentos ideológicos.

* Interrupção por parte dos militares do movimento de alfabetização de adultos liderado por Paulo Freire, no início dos anos de 60;

* Os militares implantam o Mobral, que foi uma técnica que não previa um círculo de alfabetização;

* Não era objetivo dos militares desenvolver qualquer mentalidade política para os adultos;

* O governo militar no Brasil não tinha o intuito de melhorar a educação no país, seu objetivo era muito mais político influenciado pelo contexto internacional. 
* As autoridades militares usaram vários meios para "decapitar" os movimentos oposicionistas dentro das faculdades;

* Instituíram a Educação Moral e Cívica, por meio do Decreto- Lei no 869 de 12 de dezembro de 1969 visando influenciar no contexto escolar nos diversos níveis de ensino: fundamental, médio e superior, ou seja, obediência, ordem, passividade, fé, "liberdade responsável" e patriotismo, faziam-se presentes nos livros didáticos.

* Em 1971, os militares alteraram o ensino profissionalizante, promulgando a lei $\mathrm{n}^{0}$ 5.692, a qual excluía a pré-escola, enquanto os professores lutavam pela aprovação da Lei de Diretrizes e Bases (LDB), que englobava uma reforma educacional como um todo.

* O governo ditatorial brasileiro, por meio do MEC firmou com o governo americano acordos internacionais de integração. A Reforma Universitária brasileira foi uma forma de equiparação ao modelo norte-americano.

* Sobre o ensino profissionalizante, os militares resgataram uma antiga discussão: o $2^{\circ}$ grau clássico era voltado a dar o suporte para o estudante ingressar na universidade, sendo, portanto, não profissionalizante.

* Com a lei profissionalizante aprovada, o Ensino Médio integra o ensino profissionalizante. A proposta tinha objetivos: necessidade de técnicos para o desenvolvimento do país.

* A educação, não era o que os militares almejavam e, sim, a manutenção de seu regime. Assim, a educação brasileira passou por esse período sem avanços, sem investimento pedagógico e sem políticas condizentes à sua importância no cenário nacional. Um exemplo disso é que segundo o censo de 1980 - após 16 anos de ditadura- a população brasileira em idade escolar era de 22.968.515, da qual 7.540.451 não freqüentavam a escola (cerca de um terço), enquanto que na área rural a população brasileira em idade escolar era de 9.229.511, da qual 4.816.806 freqüentavam a escola (quase a metade). Um grande desafio para os governos democráticos seguintes.

Fonte com adaptações: Direito e Memória 2009. 
- 1986 - 2003 - Nova República

* 1988 - Constituição Federal (CF). Destaca-se os artigos 5 (afirma que todos são iguais perante a lei, sem distinção de qualquer natureza, garantindo-se aos brasileiros e aos estrangeiros, residentes no país, a inviolabilidade do direito à vida, à liberdade, à igualdade, à segurança e à propriedade), o 203 (trata da assistência social a quem precisar), o 208 (versa sobre 0 atendimento educacional para as pessoas com necessidades educacionais especiais, preferencialmente, na Rede Regular de Ensino) e o 227(define a criação de programas para garantia de acessibilidade para as pessoas com dificuldades de locomoção), entre outros.

* 1989 - Lei n. 7.853 que cria a Coordenadoria Nacional para Integração da Pessoa Portadora de Deficiência (CORDE) e assegura os direitos básicos dos portadores de deficiência.

* 1996 - Lei n. ${ }^{\circ}$ 9394. Estabelece as diretrizes e bases da Educação Nacional, notadamente em três artigos, a saber: o 4(trata do atendimento, preferencialmente, no ensino regular), o 58(serviços de apoio, oferecidos em classes, escolas ou serviços especializados, incluindo o ensino infantil de 0 a 6) e o 59 (trata das adaptações curriculares, visando o desenvolvimento de todas as possibilidades de aprendizagem do aluno no sentido de oferecer também oportunidade para que ele conquiste uma "terminalidade" nos seus estudos, mesmo que seja específica para que possa favorecer a inserção no mercado de trabalho).

* 1998 - lançamento dos Parâmetros Curriculares Nacionais do Ministério da Educação que fornece as estratégias para a educação de alunos com necessidades educacionais especiais no que tange às Adaptações Curriculares.

* 2001 - Plano Nacional de Educação. Ele explicita a responsabilidade da União, dos Estados e Distrito Federal e Municípios na implementação de sistemas educacionais que assegurem o acesso e a aprendizagem significativa a todos os alunos.

* 2001 - Diretrizes Nacionais para a Educação Especial na Educação Básica, Resolução do Conselho Nacional de Educação/ Câmara de

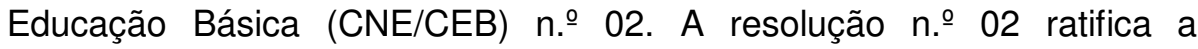
importância de que todos os alunos podem aprender juntos numa escola de qualidade. 
* 2001 - Decreto n. 3.956 de 8 de outubro que reconhece a Convenção Interamericana para Eliminação de todas as formas de discriminação contra pessoas portadoras de deficiência.

* 2002 - Lei no. 10.436. Ela reconhece a Língua Brasileira de Sinais (LIBRAS) como meio legal de comunicação e expressão dos surdos e o ensino da Língua Portuguesa como segunda língua.

* 2002 - Portaria no. 2.678. Esta portaria aprova as diretrizes e normas para o uso, o ensino, a produção e a difusão do sistema Braille em todas as modalidades de ensino, compreendendo o projeto da Grafia Braille para a Língua Portuguesa e a recomendação em todo o território nacional.

- 2007 - Decreto 6.094. Implementa o Plano de Desenvolvimento da Educação, tendo como eixos a formação de professores para a educação especial e o compromisso com a educação para todos, viabilizando a garantia do acesso, da permanência no ensino regular e o atendimento às necessidades educacionais especiais dos alunos, bem como fortalece o ingresso desses nas escolas públicas.

* 2008 - Decreto 6.571. Trata do atendimento educacional especializado. Tem a finalidade de ampliar a oferta do atendimento educacional especializado aos alunos com deficiência, transtornos globais do desenvolvimento e altas habilidades ou superdotação, matriculados na rede pública de ensino regular. Fonte: Texto com adaptações: Educação Inclusiva: um desafio para a educação de jovens e adultos. http://www.fe.unb.br/eja/modIV/resource/view.php?id=376 


\subsection{Breve histórico sobre a Educação de Jovens e Adultos no Brasil}

Pode-se afirmar que a EJA tem um papel fundamental na construção do conhecimento para os cidadãos que em tempo hábil não tiveram a oportunidade de concluir sua formação escolar. No entanto, é importante destacar que estes estudantes, na maioria, são pessoas com cultura própria. Sendo assim, acredita-se que o educador precisa identificar o potencial do aluno para que aconteça o sucesso da aprendizagem. Essa concepção é reforçada pelo Documento Base Nacional Preparatório a VI CONFINTEA (2008):

(...) cabe abordar a concepção ampliada de educação de jovens e adultos, que entende educação pública e gratuita como direito universal de aprender, de ampliar e partilhar conhecimentos e saberes acumulados ao longo da vida, e não apenas de se escolarizar. Em outras palavras, os educandos passam a maior parte de suas vidas na condição de aprendizes e, portanto, muitas são as situações de aprendizado que vivenciam em seus percursos formativos.

A construção sobre os verdadeiros objetivos da EJA leva esta modalidade de ensino oferecer condições para o educando transformar sua realidade, obtendo melhores condições de vida na reescrita de sua própria história. Assim sendo de fundamental importância acreditar no potencial e nas possibilidades de crescimento do ser humano

Em consenso com o documento, entende-se que educar é muito mais que reunir pessoas numa sala de aula e transmitir-lhes um conteúdo pronto. Acredita-se que o papel do professor, especialmente do professor que atua na EJA no CEE, deve primar para compreender melhor o aluno e sua realidade diária.

Essa perspectiva reitera a importância do conceito de diversidade. Segundo Ferreira (2001), a palavra diversidade vem do latim diversitas e significa diferença, dessemelhança, variedade, divergência, oposição, contradição. Pode-se dizer que a diversidade traz um desafio enriquecedor ao processo de ensino-aprendizagem, tornando-o mais responsável e compromissado com o processo de formação e desenvolvimento das pessoas.

O pleno entendimento deste conceito facilita o reconhecimento dos diversos recortes dentro da ampla temática da diversidade presente no ambiente escolar (negros, índios, trabalhadores do campo, mulheres, portadores de necessidades especiais, homossexuais, entre outros grupos). Este desafio coloca a escola frente à luta em respeito à diferença e na pratica da cidadania. 


\subsection{Sujeitos}

Com base no Documento Base Nacional Preparatório a VI CONFINTEA (2008), é importante compreender que:

Pensar sujeitos da EJA é trabalhar para, com e na diversidade. A diversidade é constituída das diferenças que distinguem os sujeitos uns dos outros - mulheres, homens, crianças, adolescentes, jovens, adultos, idosos, pessoas com necessidades especiais, indígenas, afro-descendentes, descendentes de portugueses e de outros europeus, de asiáticos, de latinoamericanos, entre outros.

Nessa concepção dos sujeitos da EJA, verifica-se que a educação vem captando novas dimensões em face das mudanças ocorridas na sociedade. Ela torna-se talvez a maior responsável pelo crescimento social, pois é percebido o paralelo entre o progresso escolar/formação com mentes conscientes, reflexiva, críticas e exigentes.

Torna-se fundamental a desconstrução de discursos e conceitos firmemente arraigados no contexto social e que compromete o desenvolvimento dos educandos. Precisa-se ter a clareza destes conceitos para que ao trabalhar com o educando da EJA este tenha a possibilidade de desenvolver seu pensamento crítico e gerar novos comportamentos.

Cabe ressaltar que a EJA direcionada para as verdadeiras necessidades dos educandos e amparada pela legislação vigente, deve direcionar suas ações para a execução de estratégias que permitam conquista da ação do reconhecimento da igualdade humana de direitos e o acesso aos direitos civis, pela restauração de um direito negado, além de propor a igualdade de oportunidades de acesso e permanência na escola como também viabilizar a atualização permanente de conhecimentos e aprendizagens contínuas. 


\subsection{Intersetorialidade da EJA}

Esse é um ponto a ser vencido por toda sociedade, pois a educação é responsabilidade de todos. As políticas educacionais devem estar consolidadas com todos os setores em prol do intercâmbio de compromisso, participação, contribuição e construção nas tarefas de educar.

Essa parceria deve ser principiada e efetivada por meio de diálogos e ações entre órgãos públicos que interferem diretamente na vida educacional da sociedade, onde tal interação venha sanar problemáticas específicas que quando persistentes impossibilitam o sucesso pedagógico.

Neste sentido Documento Base Nacional Preparatório a VI CONFINTEA (2008) cita:

Reconhecer a intersetorialidade da EJA e potencializá-la implica múltiplos desafios e requer parcerias e envolvimento no processo educativo, com a integração de todas as esferas governamentais (federal, estadual, municipal e distrital) e da sociedade civil, relacionadas com o campo do trabalho, da saúde, do meio ambiente, da segurança pública, da assistência social, das culturas da comunicação, entre outras.

A prática da intersetoridade contribui para a formação integral do ser que exclui a postura individualista fortalecida por construção social no resgate de uma sociedade colaborativa para romper as dificuldades enfrentadas pelos jovens e adultos trabalhadores. A intersetoriedade deve ser vista e praticada como uma ação em conjunto, onde o beneficiado não é somente o aluno e sua família. Vale pensar que sociedade melhor formada, estruturada e organizada reduz os índices de criminalidade, desemprego e da desigualdade social, além de contribuir para uma sociedade mais justa, crítica e reflexiva, isto é, termos mais seres partícipes na sociedade. 


\subsection{Recursos e financiamento}

No Documento Base Nacional Preparatório a VI CONFINTEA (2008), percebe-se a importância que deve ser evidenciada por diversas instituições responsáveis pela formação do educando da EJA no que diz respeito a manutenção dessa modalidade de ensino. Destaca-se conforme o documento que:

O desafio de fortalecer o atendimento e a qualidade na EJA é tarefa que exige repensar o atual modelo de colaboração, com o objetivo de definir a responsabilidade dos entes federativos, daí a necessidade de expressar indicadores e responsabilidades da União, de Estados, do Distrito Federal e dos Municípios, respeitando e definindo os diferentes papéis de cada um na constituição das redes públicas, para que a EJA seja garantida pelo poder público. Faz-se necessário avançar na constituição do regime de colaboração entre esferas de governo e na definição de responsabilidades dos entes federados. No campo da EJA, historicamente, tem sido fundamental que a União cuide das escolhas e dos rumos da política proposta, pela influência que exerce sobre os demais entes federativos e, neste caso, especificamente, pela representação do MEC.

Nesse sentido, entende-se que a importância de investir na educação de jovens e adultos no Brasil reside, primeiramente, no reconhecimento dessas pessoas como sujeitos de um direito universal que, em virtude de situações de desigualdades, Ihe foi negado no passado e lhe é dificultado no presente.

Acreditam-se, ao propor as políticas públicas educacionais, na tomada de decisões como instrumentos concretizadores de direitos que evidenciem mudanças de comportamentos que tem sido reproduzido e não colaboram com o progresso dos educandos.

Por isso, a necessidade de parcerias que promovam a ampliação do saber de modo a garantir o direito à organização do atendimento a jovens e adultos em tempos e espaços pedagógicos diferenciados no sistema nacional de educação. Essa ação colabora na minimização da reprodução da oferta de EJA nos velhos moldes do ensino supletivo que, muitas vezes, adota o pensamento equivocado que os educandos têm pressa, por isso a escola oferece pouco conteúdo em pouco tempo.

Nota-se que a realidade das propostas públicas para a EJA nos dias atuais tenciona a mudança desse raciocínio e demonstra que não há como pensar em educação como direito público subjetivo apenas no ensino fundamental para jovens, adultos e idosos, sem uma clara definição no sistema de ensino, mas de mudanças necessárias nas estratégias de acesso, permanência e qualidade do conhecimento produzido. 


\subsection{EDUCAÇÃO ESPECIAL - EJA NO CONTEXTO MERCADO DE TRABALHO}

Ao longo dos anos, a educação especial ofertada dentro dos Centros de Ensino Especiais tem passado por mudanças e reformulações importantes, com o objetivo de melhorar a qualidade de ensino e promover uma inclusão de sucesso em todos os âmbitos sociais. Destaca-se a implantação da modalidade de Educação de Jovens e Adultos que veio devolver a essa clientela de alunos matriculados no Centro de Ensino Especial, a esperança de serem tratados com respeito, de terem seus direitos cumpridos e amparados por lei e principalmente incluídos no mundo de trabalho, recebidos como um cidadão autônomos e participativos na sociedade.

Anteriormente, os alunos matriculados nas turmas de alfabetização mesmo com perspectivas acadêmicas, quando completavam 15 anos, eram encaminhados para as oficinas pré-profissionalizantes ficando dessa forma sem a parte acadêmica tão importante e indispensável para a concretização de uma inclusão de sucesso. Hoje, pode-se dizer que os dois processos ocorrem simultaneamente, garantindo ao aluno uma oportunidade de se profissionalizar e escolarizar para ter acesso ao mundo do trabalho.

Dessa forma, busca-se adequar o currículo a fim de atender às necessidades da profissionalização que são: habilidades básicas (identificação de placas, utilização do sistema bancário, identificação dos documentos essenciais ao cidadão, entre outros); Habilidades de gestão (saber trabalhar em equipe, iniciativa profissional, participação nas discussões, autonomia etc). Com o devido cuidado em oferecer para cada um as habilidades necessárias de acordo com suas possibilidade e potencialidades respeitando o tempo do aluno e a flexibilidade para aplicar as devidas adaptações.

Quando se fala em inclusão no mundo de trabalho, acaba se tornando um assunto bastante polêmico, pois o aluno deficiente intelectual fica excluído devido seu perfil não corresponder às exigências do mercado. Este, por sua vez, exige mão de obra qualificada, que tenha pelo menos leitura, escrita e domínio nas quatro operações fundamentais.

Ao buscar uma capacitação, estágio e colocação no mundo do trabalho para esse aluno, freqüentemente surgem exigências como as citadas anteriormente que se transformam em barreiras, dificultando o acesso à inclusão. Às vezes, o aluno até corresponde e está pronto, mas a família demonstra medo e insegurança em inserir o aluno no mercado de trabalho e isto acarreta em perda do benefício do INSS, pago conforme

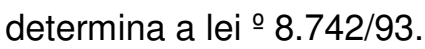

O decreto no 3.293/99, em seu Artigo 36, estabelece que a empresa com cem ou mais empregados esteja obrigada a preencher de dois a cinco por cento de seus cargos com beneficiários da Previdência Social reabilitados ou com pessoas Portadoras de Deficiência habilitadas" O mencionado decreto, em seu Artigo 36, se refere às pessoas com deficiência 
de forma geral para efeitos de contratação limitando as empresas a contratar pessoas com deficiência física, auditiva e visual ficando excluídos os deficientes intelectuais.

A inclusão está assegurado na Constituição Federal no Artigo 1ํ, onde afirma que:

A República Federativa do Brasil, formada pela união indissolúvel dos Estados e Municípios e do Distrito Federal, constitui-se em Estado Democrático de Direito e tem como fundamentos:

I - a soberania;

II - a cidadania;

III - a dignidade da pessoa humana;

IV - os valores sociais do trabalho e da livre iniciativa;

$\mathrm{V}$ - o pluralismo político

Ainda no artigo 3ํㅡá reforço ao artigo citado anterior:

Constituem objetivos fundamentais da República Federativa do Brasil:

I - construir uma sociedade livre, justa e solidária;

II - garantir o desenvolvimento nacional;

III - erradicar a pobreza e a marginalização e reduzir as desigualdades sociais e regionais;

IV - promover o bem de todos, sem preconceitos de origem, raça, sexo, cor, idade e quaisquer outras formas de discriminação.

Porém, apesar dos registros constantes na Constituição Federal de 1988, em alguns momentos os direitos a participação efetiva na sociedade por parte dos portadores de necessidades educativas especiais não é respeitada na íntegra. No campo da educação, ainda se esbarra com professores despreparados, comunidade e pais cheios de resistências e preconceitos, espaços físicos e materiais inadequados para o trabalho. Logicamente que não se pode generalizar, pois a inclusão também apresenta muitas histórias de sucesso, entretanto, mínimas diante da complexidade da educação no Distrito Federal.

No que diz respeito à inserção no mercado de trabalho, a Constituição Federal de 1988 no seu artigo $37^{\circ}$ é bem clara: "reservará percentual dos cargos e empregos públicos para as pessoas portadoras de deficiência e definirá os critérios de admissão". Os direitos são claros na Constituição, mas não são respeitados e quanto ao mundo do trabalho, a discriminação ainda é maior por serem julgados como incapazes pelas limitações intelectuais que possuem.

Para que a inclusão social tenha sucesso, é necessário que as escolas ofereçam qualificação profissional, que busquem parcerias com os Centros de Educação Profissional para oferecer vagas em cursos profissionalizantes com o intuito de reduzir distâncias e promover a inclusão. Sendo que a mesma só acontecerá, indiscriminadamente, quando as principais instituições sociais estiverem abertas para o novo, com uma nova mentalidade, 
mais sensibilizadas e sem preconceitos. A capacitação profissional é o primeiro passo para que o aluno com Deficiência Intelectual concorra a uma vaga com igualdade de condições e oportunidades e se sinta um verdadeiro cidadão, nessa sociedade inclusiva e rica em diversidade.

A Constituição Federal estabelece em seu artigo $1^{\circ}$ incisos II e III sobre a garantia dos direitos, inclusive a promoção do bem de todos, sem preconceitos de origem, raça, sexo, cor, idade e quaisquer outras formas de discriminação e em seus artigos 205, 206 e 208 trata do direito de todos à educação, que deve visar o pleno desenvolvimento da pessoa, seu preparo para a cidadania e sua qualificação para o trabalho. Assim, cabe à escola trabalhar a independência e autonomia dos discentes, oferecendo inclusive, orientação e acompanhamento para suas famílias, pois muitos desconhecem as leis dos direitos do Portador de Deficiência bem como direitos humanos e trabalhistas.

No sentido de contribuirmos para a inclusão do alunos da EJA/DI na proposta de trabalho, nos deparamos com as dificuldades e limitações que o mercado de trabalho impõe, desde de pré requisitos como boa leitura e escrita, independência de locomoção, resolução de problemas inesperados, independência e autonomia de alimentação e medicação em horários certos à perca do benefício do aluno. Assim, compreendemos que o mundo do trabalho melhor contribuirá aos nossos educandos, tendo em vista que oferece leque maior de possibilidades de inserir os alunos no espaço "trabalho", além de podermos vislumbrar a criação de cooperativas e associações que venham a favorecer com os trabalhos desenvolvidos pelos alunos em questão e por não solicitar a exclusão do beneficio do educando. Pois ao mesmo tempo em que este aluno é considerado "incapaz", ele também é, muitas vezes, a única fonte de renda familiar. 


\section{ATIVIDADES}

A luta pela inclusão é incansável, pois não se limita somente em inserir a pessoa com deficiência em escolas inclusivas, mas também contribuir para o desempenho, inserção e permanência no mundo do trabalho.

Nesta direção, os professores da EJA na educação especial com alunos diagnósticos de déficit intelectual do CEE 02 de Ceilândia desenvolvem atividades pedagógicas e de trabalho que visam acompanhar, preparar, avaliar e inserir os educandos no mundo do trabalho.

Atualmente, a escola conta com o apoio do SOT (serviço de orientação para o trabalho) que é constituído pelo coordenador (a) das oficinas/EJA, professor (a) de gestão para o trabalho, professores (as) regentes, professores (as) das oficinas profissionalizantes e sócio-profissionalizantes.

O objetivo do SOT é "proporcionar atendimento educacional especializado voltado a desenvolver competências biopsicossociais que favoreçam o processo de socialização e preparação para a inclusão no mundo do trabalho, com maior autonomia e independência aos alunos das oficinas pedagógicas”. (Orientação Pedagógica, 2010)

Dado as limitações e especificidades dos alunos com DI, o CEE está estruturado e organizado para oferecer oficinas em dois módulos distintos:

- Oficinas sócio-profissionalizantes, a qual abrange todos os contextos que o estudante convive: escola, família, comunidade e trabalho. $\mathrm{O}$ aluno recebe atendimento diário com duração de 2 horas e meia e o planejamento das atividades é feito de acordo com o perfil do estudante, respeitando suas limitações. Nessas oficinas, são trabalhados conteúdos como: autonomia, habilidades psicomotoras, integração social e habilidades básicas de gestão.

- Oficinas Profissionalizantes: no planejamento das atividades a serem desenvolvidas com os educandos da EJA adota-se como meta principal preparar o aluno para o mundo trabalho, de forma que seja vencido o estigma da discriminação e preconceito uma vez que é observado que mesmo com a necessidade especial o educando tem habilidades que permitem desempenhar uma profissão por meio de adaptações fazendo com que ele apenas exerça os procedimentos a serem executados para a concretização da ação de maneira diferente.

As oficinas de profissionalização são de grande importância, pois deseja qualificar o aluno e encaminhá-lo ao mundo do trabalho de acordo com suas habilidades onde 
descobrirão novas potencialidades e aptidões. Cabe esclarecer que as oficinas pré e profissionalizantes não devem ser oferecidas isoladamente, mas sim articulada com a Educação de Jovens e Adultos, considerando as devidas adequações curriculares.

A intenção deste projeto de intervenção prima pela concretização dos objetivos, para tanto, acredita-se que a parceria entre os diversos atores poderá ampliar as possibilidades de acesso ao mundo do trabalho para os alunos da EJA com DI. Ressalta-se que os além dos pesquisadores envolvidos neste projeto, deve contar com a participação a professor (a) regente, professor (a) de oficinas pedagógicas e com o (a) profissional do SOT.

Nesse ínterim, pode-se afirmar que serão desenvolvidas as seguintes atividades:

- Avaliar o mundo de trabalho e orientar a oferta de cursos de qualificação para o trabalho do programa das Oficinas Pedagógicas.

- Estabelecer parcerias com os Centros de Educação Profissional ou outras instituições para a promoção de cursos, palestras e outras.

- Participar em atividades externas como fóruns, visitas às empresas, dentre outros eventos em busca de espaço para os alunos.

- Flexibilizar currículo para o módulo de oficinas de qualificação para o trabalho, adequando às atividades de acordo com o perfil de cada aluno.

- Preparar e encaminhar os estudantes com deficiência intelectual ao mundo do trabalho.

- Buscar de vagas para serviços e estágio.

- Estabelecer parcerias para a aquisição dos materiais necessários para o andamento dos trabalhos a serem executados;

- Elaborar documento para apreciação do Conselho Escolar com vistas a definir verbas para a compra dos materiais.

- Realizar feiras e eventos para a exposição e vendas dos materiais produzidos pelos educandos.

Todo o trabalho da EJA para aluno com DI, na perspectiva de inserção no mundo do trabalho está fundamentado nos quatro pilares da educação que são: aprender a conhecer, aprender a fazer, aprender a conviver e a ser possibilitado a esses alunos não só mais uma capacitação, mas sim elevar sua auto-estima e autonomia, completando assim a sua formação humana. 


\section{CRONOGRAMA}

\begin{tabular}{|c|c|}
\hline Período & Ação \\
\hline ஜి & 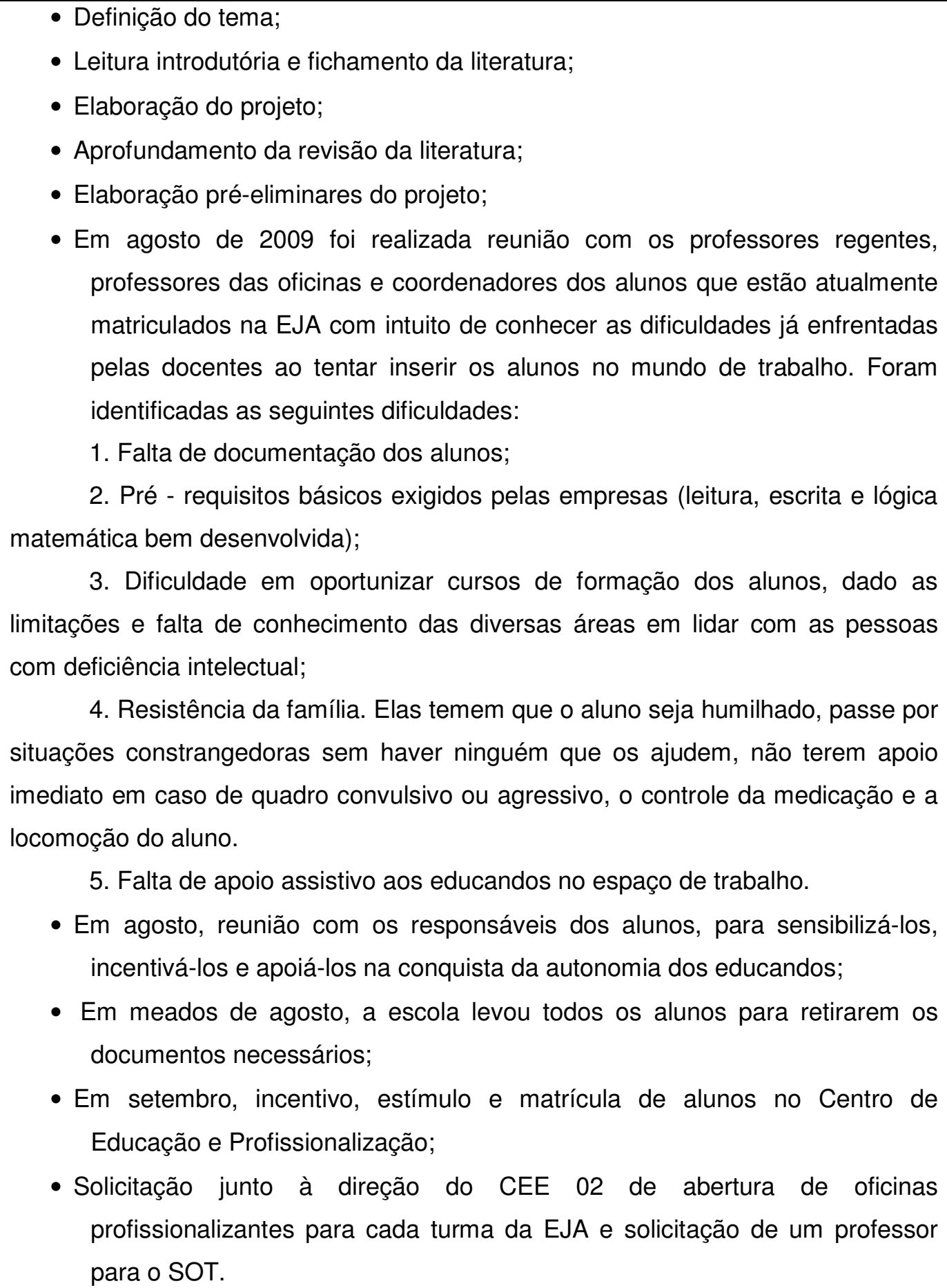 \\
\hline
\end{tabular}




\begin{tabular}{|c|c|}
\hline 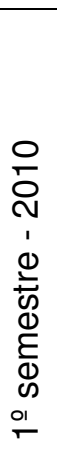 & $\begin{array}{l}\text { - Continuar os encontros com a orientadora nos dias indicados; } \\
\text { - Ampliar as leitura introdutória e fichamento da literatura; } \\
\text { - Elaboração do projeto; } \\
\text { - Aprofundamento da revisão da literatura; } \\
\text { - Elaboração pré-eliminares do projeto; } \\
\text { - Entrega de partes do projeto no ambiente virtual; } \\
\text { - Ajuste e alterações necessárias no documento conforme orientações. }\end{array}$ \\
\hline 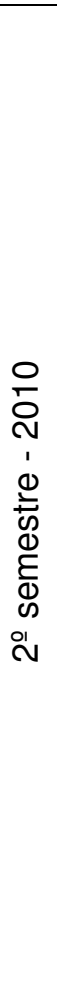 & $\begin{array}{l}\text { - Promover encontros na escola, objetivando favorecer a troca de experiência; } \\
\text { - Favorecer a integração entre as instituições responsáveis pela formação do } \\
\text { educando visando inserir no mundo do trabalho; } \\
\text { - Facilitar a construção da rede de interação entre a família, escola, } \\
\text { comunidade e instituições públicas e privadas que ofereçam possibilidade } \\
\text { de trabalho; } \\
\text { - Melhorar a autoestima e conscientização das pessoas envolvidas; } \\
\text { - Promover palestras com temática de interesse da comunidade, família e } \\
\text { - educandos; } \\
\text { estabelecer com os professores meios de trabalho para resgatar a auto- } \\
\text { - Fomentar a troca de experiência das famílias com profissionais da área de } \\
\text { saúde e de humanas contribuindo para o crescimento e a ampliação da } \\
\text { visão dos mesmos sobre o tema. } \\
\text { - Participar de eventos relacionados com o mundo do trabalho, visando à } \\
\text { aquisição de novos conhecimentos }\end{array}$ \\
\hline
\end{tabular}




\section{ACOMPANHAMENTO E AVALIAÇÃO}

A intenção da aplicação deste projeto é promover uma educação que busca desencadear um processo de transformação social, visando a promoção do debate acerca dos problemas sociais e de apoio à participação do educando com necessidades especiais no mundo de trabalho, para tanto:

1. Realização de diagnóstico

- Será feito um levantamento sobre o conhecimento das famílias que são atendidas no Centro de Ensino Especial, o que compreendem em relação ao mercado de trabalho para que seja possível direcionar as ações do projeto; isso se dará por meio de um questionário em relação a temática em questão;

- Promoção de debates e estudos sobre o projeto visando parcerias;

- Elaboração de metas e ações ao encontro de apoio junto aos órgãos competentes, principalmente da rede pública.

2. Palestras

- O contato com a equipe multidisciplinar será utilizado como uma forma de proporcionar ao público participante a possibilidade de se tornar um agente multiplicador de informação relacionada à inclusão do educando no mundo do trabalho por intermédio da formação e preparação adequada.

Nesta projeção de pensamentos cabe a escola orientar e abrir espaços, dando o passo inicial para que estabeleça, entre todos os envolvidos, oportunidades de diálogo, visando à ampliação das ações. 


\section{REFERÊNCIAS}

BRASIL/MEC. Curso Educação na Diversidade. CDROM Disco 01, c2006.

BRASIL. A Construção da Proposta Pedagógica da Escola: A escola de cara nova. Planejamento. São Paulo: SE/CENP, 2000. Ministério da Educação. Secretaria de Educação Básica. Orientação Curricular Educação Básica - Ensino Fundamental - Série e Anos Iniciais, 1998.

, Constituição da República Federativa do Brasil. Brasília, Distrito Federal, 1998.

Lei de Diretrizes e Bases da Educação Nacional - LDB - Lei 9.394 de 1996.

Brasília: Câmara dos Deputados, 1997.

, Parâmetros Curriculares Nacionais - PCN de 1999. Brasília

MEC. Documento Base DOCUMENTO FINAL.2010.

CARVALHO, R. E. Escola Inclusiva: reorganização do trabalho pedagógico. Porto Alegre: Mediação, 2008.

CUNHA, Conceição Maria da. Introdução - discutindo conceitos básicos. In: SEED-MEC Salto para o futuro - Educação de jovens e adultos. Brasília, 1999.

CURY, Carlos R. Jamil. Os Conselhos de Educação e a gestão dos sistemas. In: FERREIRA, N. S. C.; AGUIAR, M. A. (Orgs). Gestão da educação: impasses, perspectivas e compromissos. São Paulo: Cortez, 2000.

DISTRITO FEDERAL. Secretaria de Educação. Diretrizes Pedagógicas Secretaria de Estado de Educação do Distrito Federal 2009/2013.

Secretaria de Estado de Educação. Regimento Escolar das Instituições

Educacionais da Rede Pública de Ensino do Distrito Federal, 5a. Ed - Brasília, 2009. Centro de Ensino Especial. Projeto Político Pedagógico. Ceilândia, 2010. 
LUCK, H. A escola participativa: trabalho do gestor escolar. 2 ed. Rio de Janeiro: DP\&A, 1998.

NAVARRO, Ignez Pinto, BRASIL, Indicadores de Qualidade para a Mobilização da Escola. Ministério da Educação. Secretaria de Educação Básica. Programa Nacional de Fortalecimento dos Conselhos Escolares. Vol. 1. 2004

Leôncio José Gomes. O surgimento dos Fóruns de EJA no Brasil: articular, socializar e intervir. In: RAAAB, alfabetização e Cidadania - políticas Públicas e EJA. Revista de EJA, n.17, maio de 2004.

SANTOS, Carla Andréia Simão. Projeto Político Pedagógico, Equipe Gestora e Conselho Escolar do Centro de Ensino Especial 02 de Ceilândia. Brasília, 2009.

VIEIRA, Sofia Lerche. Educação Básica: política e gestão da escola. Fortaleza: Líber Livro, 2009

Site:

http://www.universia.com.br/carreira/materia.jsp?materia=13604, acessado e disponível em 06/06/2010 às 21:40.

http://www.acessibilidade.net/at/kit2004/Programas\%20CD/ATs/cnotinfor/Relatorio Inclusiva /report adaptacao curricular pt.htmlem 20/06/2010 ás 17:24

http://www.direitomemoria.org.br/MÓDULO 2 - Direitos Humanos.UNIDADE \| - Vítimas da Violência. Aula 14 - CENSURA NA EDUCAÇÃO. Acesso disponível em 19.06.2010, às 21:00.

http://portal.mec.gov.br/seesp/arquivos/pdf/cartilha06.pdfem. acessado e disponível em 20/06/2010, ás 17:41 
ANEXO 


\section{I - DADOS DE IDENTIFICAÇÃO:}

Escola: Centro de Ensino Especial 02

Ato de criação: Resolução 6443/CD - 16/12/1998

Código SIGE da Instituição Educacional: 0041

Entidade Mantenedora: Secretaria de Estado e Educação do Distrito Federal

Modalidade de Ensino: Educação Especial: deficiência intelectual, deficiência múltiplas, oficinas semi-profissionalizantes, educação de jovens e adultos, educação precoce e transtorno global do desenvolvimento.

Localização: Urbana

Endereço: QNO 12 - Área Especial "G" - Setor "O" - Ceilândia

Município: Ceilândia / DF

\section{Equipe de Direção e coordenação}

Diretora: Márcia Serafim

Vice-diretor: Itamar Assenço

Supervisora Pedagógica: Carla Andréia Simão

Supervisora Administrativa: Alessandra Bonfim

Chefe de Secretária: Alessandra Barcelos

Coordenadora Currículo Adaptado e Funcional: Joelma Oliveira

Coordenadora da EJA: Simone Mamede

Coordenadora de Atendimento Complementar: Lília Batista 


\title{
II - APRESENTAÇÃO
}

\begin{abstract}
"A relevância de um projeto escolar consiste no planejamento que, evita improvisação, serviço malfeito, perda de tempo e de dinheiro. Com planejamento, fica bem claro o que se pretende e o que deve ser feito para se chegar aonde se quer. Um bom Projeto Político Pedagógico dá segurança à escola. Escolhem-se as melhores estratégias o que facilita seu trabalho, pois o mesmo está fundamentado no Projeto que norteia toda Unidade Escolar. Isso se faz imprescindível para se ter um rumo, visando obtenção de resultados de forma mais eficiente, intensa, rápida e segura. A escola deve buscar um ideal comum: fazer com que todos os alunos aprendam. Uma boa sugestão é nomear comissões de pais e encarregá-las de organizar campeonatos esportivos nos finais de semana na quadra da escola, cuidar dos banheiros ou da biblioteca." (Fragmento retirado: Projeto Político Pedagógico/ A Identidade da Escola Sistema de Ensino Portal Educação e Sites Associados)
\end{abstract}

Preparar o aluno para o exercício da cidadania em ambiente de socialização em busca de conhecimentos é uma das funções da escola. Esse contexto é trabalhado em consonância com as constantes transformações da sociedade no intuito de aprimorar e oferecer melhor qualidade de vida aos cidadãos.

O mundo vive mudanças pelo acompanhar do progresso em todos os âmbitos. O mesmo não poderia ser diferente à educação especial, e assim nos atentamos a importância da elaboração e aplicação do Projeto Político Pedagógico (PPP) para alunos com necessidades educativas especiais, sendo este visualizado como uma ponte para sucesso dos educandos em questão.

Para Kuenzer (2002), essas mudanças buscam nova relação entre o homem e o conhecimento, tendo em vista que o avançar em técnicas, tecnologias, metodologias e estratégias não se esgotam, mas dão continuidade ao caminhar por mais conhecimentos.

O fazer pedagógico, desta Instituição de Ensino, é entendido como um processo de construção e transformação do indivíduo para sua atuação na sociedade, é complexo e dinâmico, estando intimamente ligado ao contexto no qual está inserido, pois o aspecto evolutivo do mundo globalizado contribui para a educação assumir o quadro de promoção das competências que envolvem a formação do ser em sua totalidade. 
Para tornar este processo mais efetivo é importante conhecer a realidade com a qual se trabalha e a partir daí planejar as ações. Desse modo, é de fundamental importância que as escolas construam uma proposta pedagógica que norteie suas ações.

Com a elaboração da proposta pedagógica é possível detectar como se encontra a escola em seus aspectos físicos, financeiros, recursos humanos e o processo pedagógico, então delinear alguns caminhos a serem percorridos durante 0 ano letivo.

Acreditamos que tal proposta beneficiará o processo pedagógico, pois nela está presente a contribuição de toda a comunidade escolar que participou, ativamente, de sua elaboração.

Cabe ressaltar que esta proposta é percebida como caminhos traçados, os quais podem ser modificados ao longo do processo, pois outros objetivos, estratégias, metas e ações surgirão no decorrer do trabalho.

"Num projeto pedagógico tudo é relevante na teia das relações escolares, porque todas elas são potencialmente educativas ou deseducativas. Ensinar bem, por exemplo, não é apenas ensinar eficientemente uma disciplina, mas é também o êxito em integrar esse ensino aos ideais educativos da escola. Enfim, o importante é a motivação e o empenho comum numa reflexão institucionalmente abrangente e o firme propósito de alterar práticas nos sentidos indicados por essa reflexão. Para isso, não há fórmulas prontas e convém não esperar auxílio de uma inexistente "ciência dos projetos" ou de roteiros burocratizados." (Publicação: A escola de cara nova. Planejamento. São Paulo: SE/CENP, 2000 Páginas: 18-24).

A proposta Pedagógica é um instrumento norteador das ações educativas planejadas pela Instituição por um determinado período, com finalidades e objetivos definidos, as quais possibilitam detectar como se encontra a escola e assim poder estruturar e reestruturar pontos fundamentais para o bom andamento do trabalho pedagógico, bem esclarecido conforme Vilas Boas:

"A adoção da expressão trabalho pedagógico requer que a escola assuma duas posturas. A primeira é a de que o trabalho pertence a quem concebe, executa e avalia. Não se aceita que alguém planeje o que o outro irá realizar, pois se retira do executor suas possibilidades de domínio sobre o processo de trabalho, de comprometimento com o mesmo e de senti-lo como algo prazeroso e gratificante". (Vilas Boas, 1998. p. 180) 
Com intuito de estarmos apoiados em um projeto que vise acompanhar o melhor desempenho de todos os segmentos escolar, partimos da premissa que necessitamos e devemos tencionar este em tendências sócio-político-cultural e a legislação em vigor, sempre com tomadas de decisões que resultem em mudanças significativas dos princípios, finalidades e objetivos institucionais.

A proposta, no entanto, deve ser dinâmica e atual para atender as expectativas e interesses no âmbito educacional, bem como é possível detectar como se encontra a escola em seus aspectos físicos, recursos humanos, financeiros e o processo pedagógico, para a partir daí delinear alguns caminhos a serem percorridos durante todo o ano letivo.

Registramos, ainda, que atendendo a necessidade de elaboração, aplicação/ desenvolvimento, avaliações, gestão compartilhada, entre outros, faz-se necessário que o projeto seja válido pelos anos letivos de 2010 e 2011, realizando no início do ano letivo de 2011 uma revisão para sanarmos possíveis falhas, obstáculos e reforçarmos os pontos positivos, assim havendo reestruturação dos tópicos que devem responder exclusivamente pelo ano letivo em debate.

\title{
III - CONTEXTO HISTÓRICO DA INSTITUIÇÃO
}

\author{
“.... mire, veja: o mais importante e bonito do mundo é isto; \\ Que as pessoas não estão sempre iguais, ainda não foram. \\ Terminadas, mas que elas vão sempre mudando. Afinam ou \\ desafinam. Verdade maior. "É o que a vida me ensinou." \\ (João Guimarães Rosa)
}

O Centro de Ensino Especial 02 de Ceilândia, localizado na QNO 12 - área especial "G" - foi inaugurado no dia 17 de dezembro de 1998, com o objetivo de ampliar $\mathrm{o}$ atendimento aos alunos com necessidades educativas especiais em Ceilândia.

Esta é uma instituição pública, subordinada a Subsecretaria de Educação Pública do Distrito Federal, ligada à Diretoria de Ensino Especial e à Diretoria de Ensino de Ceilândia. É mantida com recursos públicos advindos do Plano de 
Descentralização de Recursos Financeiros, além de doações e verbas advindas de eventos promovidos pela comunidade escolar.

O CEE 02 - Ceilândia- investe na educação das pessoas com necessidades educativas especiais, proporcionando-Ihes a oportunidade de ultrapassar barreiras econômicas, sociais e culturais, com intuito de contribuir pela qualidade de vida e valorização do ser humano pela vivência e exercício pleno da cidadania.

Os alunos matriculados no CEE 02 são aqueles que após avaliação e estudos de caso não apresentaram condições, em quadro geral, a serem incluídos na rede regular de ensino. Outros (minoria) são oriundos do ensino regular, resultado de condutas/orientações educacionais as quais entenderam que os alunos com idade além do permitido para permanecerem na escola de ensino regular e por não apresentarem desempenho acadêmico e social compatível com o exigido nas propostas educacionais, foram encaminhados ao Centro com intuito de oferecermos atendimento educacional especializado, adaptado e condizente a estes educandos. Ainda há os alunos do atendimento complementar, que recebem no Centro um apoio educacional que favoreça o progresso na rede regular de ensino.

Os alunos de 0 à 3 anos são encaminhados á escola por indicação médica, são crianças que apresentam desde quadro risco (prematuro, anoxiado, filhos de mães hipertensas...) á crianças diagnóstica (paralisado cerebral, TGD, síndromes...)

Dada às especificidades dos alunos, há a necessidade de diversos recursos materiais e profissionais capacitados com intuito de melhor atender esses discentes. Os professores almejam cursos e orientações específicas, o que nem sempre é disponibilizado. Conforme citado no início deste, é de fundamental importância que o Centro de Ensino Especial complemente seu quadro de profissionais com fonoaudiólogo, fisioterapeuta, assistente social, médicos neurologistas e pediatras ou que se firmem convênios com entidades específicas.

Por serem alunos com características específicas e apresentarem viscosidade genética, muitas vezes é difícil adequar a matriz curricular a alguns atendimentos, tais como Deficiência Múltiplas (DMu) e Transtorno Global do Desenvolvimento (TGD), os quais requerem procedimentos muito específicos. 
Os atendimentos são construídos com base nas orientações educacionais vigentes e no conhecimento técnico dos professores para atender às especificidades dos estudantes, assim, aplicamos o que diz os PCNs - Parâmetros Curriculares Nacionais:

\begin{abstract}
Educação Especial - Modalidade da educação escolar. Processo educacional definido em proposta pedagógica, assegurando um conjunto de recursos e serviços educacionais especiais, organizados institucionalmente para apoiar, complementar, suplementar e, em alguns casos, subsistir os serviços educacionais comuns, de modo a garantir a educação escolar e promover o desenvolvimento das potencialidades dos educandos que apresentam necessidades educativas especiais da educação básica. (BRASIL, 1999, p.21)
\end{abstract}

Os alunos atendidos neste Centro são residentes na Ceilândia Norte, Setor "O”, Expansão do Setor "O”, Condômino Privê, Águas Lindas de Goiás e novas áreas residenciais da Ceilândia (área de chácaras).

A comunidade escolar (discentes e familiares), de forma generalizada e no campo econômico, é carente, dentro deste quadro nos deparamos com algumas situações que interferem no melhor fazer pedagógico, cito: problemas familiares onde à família busca pleno apoio e solução no ambiente escolar, pouca contribuição dos pais para compra de materiais dos alunos e nas festividades em que a escola conta com a contribuição da comunidade, pouca informação sobre as necessidades especiais e sobre como auxiliar na educação dos filhos, pouca ou nenhuma orientação quanto a seus direitos e ao do outro, pouco interesse em participar de momentos que servem de suporte para sanar dúvidas e obter conhecimentos em diversas áreas. A participação da comunidade, ainda, se restringe timidamente as reuniões pedagógicas e festas. Não há participação efetiva em todos os momentos propostos pela escola.

Quanto à parte física do CEE 02, apesar de possuir uma área ampla, o número de salas ainda é insuficiente para a nossa proposta pedagógica e para o número de alunos atendidos. O material utilizado para a construção não é de boa qualidade, requerendo vários reparos. Possui vazamentos diversos, tais como no auditório, cantina e algumas salas. A estrutura de sustentação do telhado do bloco 
três está danificada, caindo pedaços de reboco constantemente, nos expondo a grandes riscos.

A piscina maior, localizada na área externa, encontra-se desativada desde 2003, devido à não funcionabilidade estrutural e danos provocados por depredação de pessoas da comunidade que invadiram a escola. Para 2008 e 2009 foi previsto o início das obras para reestruturação da mesma. Vale registrar que no mês de setembro de 2007, no governo itinerante de Ceilândia (governador José Roberto Arruda) houve o anuncio das obras nesta escola no tocante à área da piscina em questão. Dentro desta expectativa o corpo docente e a equipe gestora estão dedicando esforços para efetivação de tal realização (obra), pois a mesma resultará em grande recurso para o melhor desenvolvimento dos nossos educandos. Porém, até o presente momento não foi realizada nenhuma ação em relação à obra.

Em função das limitações de nossa comunidade, convivemos constantemente com problemáticas que vão além das nossas responsabilidades pedagógicas, temos conhecimento de até aonde vai a nossa obrigação funcional/profissional, entretanto é impossível fecharmos os olhos as necessidades básicas pelas quais nossos discentes estão inseridos (a maioria). Assim somos levados, por questão de humanidade, a nos envolvermos em papéis que não são de nossa competência como servidores da educação, mas de nossa responsabilidade como cidadãos que valorizam a integridade do ser humano.

Além dos agravantes do parágrafo acima, o CEE 02 está localizado numa área onde o índice de criminalidade é alto, porém o efetivo disponível do Polícia Militar é baixo e não houve durante o ano de 2007, 2008 e 2009 a presença desses profissionais na escola. Necessitamos de um guarda do batalhão escolar todos os dias e horários em nosso ambiente escolar, isso contribuiria para a segurança e tranqüilidade no espaço pedagógico.

Há a idéia de que a presença de policiais em escolas especiais não é tão necessária, dada a condutas de nossos alunos que raramente se envolvem em situação que foge a normalidade ou em situações de riscos para eles e para os outros, porém essa concepção é equivocada, pois estamos inseridos em espaço regional indicador de risco e toda comunidade fica a mercê de situações 
inesperadas. O espaço além da escola pode nos oferecer risco. Ressaltamos que no corrente ano, com a inserção de turmas de atendimento complementar por este Centro, a rotatividade de alunos e ou responsáveis tende a aumentar, dificultando o controle somente por parte dos servidores da escola. Portanto faz-se necessário a presença, de forma permanente, de policiamento (Batalhão Escolar).

\section{IV- OBJETIVOS INSTITUCIONAIS}

- Oferecer atendimento especializado (orientação social/psicológica) às famílias, visando maior participação e integração no ambiente escolar.

- Proporcionar ao educando atividades que favoreçam o pleno desenvolvimento biopsicossocial

- Contribuir para conscientização da comunidade escolar em prol da inclusão educacional (ensino regular)

- Identificar, elaborar e organizar recursos pedagógicos e de acessibilidade que eliminem as barreiras para plena participação dos alunos na sociedade, considerando suas necessidades.

- Promover o conhecimento, o desenvolvimento e exercício da cidadania, visando à efetiva integração na vida em sociedade.

- Identificar e auxiliar os alunos com condições adequadas de inserção na educação especial para o trabalho

- Viabilizar atividades que visam contribuir para o desenvolvimento e apoio no campo motor, mental, social e psicológica.

- Favorecer a inclusão dos alunos com necessidades educativas especiais

- Acompanhar o desenvolvimento dos alunos incluídos

- Propiciar atendimentos variados e interdisciplinares para que o educando com necessidades especiais desenvolva o máximo de suas habilidades e competências

- Propiciar situações que levem o aluno com necessidades especiais ter uma visão mais ampla da sociedade, para sua efetiva participação social.

- Conquistar habilidades (cuidados, disciplina etc.).

- Promover atividades lúdicas e esportivas para que o ANEEs se desenvolvam com prazer e de forma harmoniosa

- Levar o aluno a perceber a auto-imagem e buscar a auto-estima e a confiança 
- Ampliar contatos com áreas afins ao trabalho: social, saúde e jurídica, visando aprimorar o atendimento ao aluno.

- Apoiar a comunidade escolar no processo de inclusão/integração dos ANEEs

- Conscientizar todos os servidores que eles também são responsáveis pela integridade física e moral dos alunos (compromisso profissional)

- Criar, efetivar, formalizar e ou reestruturar salas ambientes que ofereçam suporte ao atendimento pedagógico oferecido ao educando (leitura/contador de histórias /ludoteca, educação artística nas áreas de artes plásticas e cênicas e estimulação musical e suporte profissionalizante aos pais / mães e ou responsáveis pelos educandos).

- Diversificar os atendimentos por meio de atividades/projetos que estimulem o desenvolvimento global do aluno

- Promover a integração dos auxiliares de educação nas atividades escolares, desde o planejamento à execução.

- Viabilizar eventos que propiciem o desenvolvimento social e a integração dos alunos com necessidades educativas especiais em diversos ambientes sociais, a saber; parques, cinemas, clubes e outros.

- Integrar todas as instâncias da comunidade escolar

- Promover o ingresso dos alunos devidamente qualificados no mercado de trabalho formal e/ou informal.

- Ampliar discussões acerca dos atendimentos nas escolas inclusivas, promovendo encontros e intercâmbios.

- Aprimorar a qualidade do trabalho do professor por meio de atividades que estimulem o estudo, a pesquisa e a busca de novas metodologias, bem como a troca de experiências em grupos de estudo.

- Propiciar programas que estimulem a participação efetiva dos pais ou responsáveis na escola, assim como, possibilitar-lhes a aquisição de novos conhecimentos, tais como: palestras, oficinas de brinquedo, reuniões etc.

- Realizar estudos de caso/avaliação psicopedagógica, sistematicamente, para adequar atendimentos e horários às necessidades dos alunos.

- Oportunizar e incentivar a atualização dos servidores no trabalho junto à instituição de ensino especial, buscando melhoria e qualidade na prestação dos serviços. 


\section{V - MISSÃO}

O Centro de Ensino Especial 02 de Ceilândia, por meio da autonomia, solidariedade, respeito, ética e responsabilidade, pretende propiciar a todos que atende uma educação de qualidade, que desenvolva competências, possibilitando sua inclusão social e pedagogicamente (inclusão dos alunos do Centro na rede de ensino regular - quando possível).

A equipe trabalha respeitando as dimensões cognitivas, afetivas, psicomotoras e sociais dos alunos, criando espaços de desenvolvimento e socialização, nos quais se sintam efetivamente valorizados em sua diversidade. Objetiva desenvolver potencialidades de modo que os alunos atuem como cidadãos e sejam respeitados como tal.

Os profissionais desta Unidade acreditam em uma educação integradora, assim se esclarecem quanto às opiniões, desejos, anseios e objetivos dos pais/responsáveis dos discentes, do contexto educacional, das políticas públicas e principalmente do aluno.

Desse modo, a missão do Centro de Ensino Especial 02 de Ceilândia consiste em atuar efetivamente para que toda a comunidade escolar se desenvolva globalmente, mediante a construção de experiências participativas concretas, com qualidade e compromisso ético, tendo como horizonte à inclusão e a real participação dos alunos com necessidades educativas especiais na sociedade.

\section{VI- ORGANIZAÇÃO DO ESPAÇO FÍSICO}

Quanto à parte física do CEE 02, apesar de possuir uma área ampla, o número de salas ainda é insuficiente. O material utilizado para a construção não é de boa qualidade, requerendo vários reparos. Possui vazamentos diversos, tais como no auditório, cantina e algumas salas. A estrutura de sustentação do telhado do bloco três está danificada, caindo pedaços de reboco constantemente, expondo os alunos, professores e auxiliares a grandes riscos. 
A piscina maior encontra-se desativada desde 2003, devido à não funcionabilidade estrutural e danos provocados por depredação de pessoas da comunidade que invadiram a escola.

1) Espaço útil do Centro

- Programa de Educação Precoce (oito salas ambientes por turno)

- Classes de alunos com deficiência intelectual aliada à deficiência auditiva. (uma sala no matutino)

- Classes de alunos com deficiências múltiplas doze salas por turno)

- Classes de condutas típicas (08 salas no matutino e no vespertino)

- Classes da Educação de Jovens e Adultos (uma sala por turno)

- Oficinas pedagógicas (duas salas por turno)

- Programa de atendimento artísticos, culturais e físicos para alunos do Centro (seis salas por turno): duas psicomotricidade, duas de educação física, uma de educação artística e leitura e uma sala de leitura e artes para alunos do atendimento complementar (ludovideoteca).

- Sala de informática para atendimento complementar (uma sala)

- Sala (adaptada - antiga sala de projeção).

- Uma sala para secretária

- Equipe de apóio e aprendizagem (três)

- Sala para orientadora pedagógica (uma sala)

- Apóio administrativo (uma)

- Sala de coordenadoras (uma)

- Sala da direção (uma)

- Sala das auxiliares (uma)

- Um refeitório

- Um auditório

- Duas piscinas pequenas para atendimento dos alunos da educação precoce e alunos de 04 á 08 anos do atendimento complementar

- Uma cantina

- Quatorze banheiros divididos para deficientes, crianças pequenas, profissionais e banheiros comuns. 
- Uma arena

- Uma quadra poliesportiva

- Grande área desocupada, onde criamos um espaço para horta (criação da escola) e um galpão para prestar serviço à horta comunitária, com apóio da EMATER. Esse galpão serve de sala de aula para o atendimento em "horta" além de servir como espaço para a realização de momentos com as mães proposto pela Justiça Comunitária.

É válido registrar que temos outros espaços em nossa escola, porém estão desativados por apresentarem algum tipo de risco a integridade física de toda comunidade escolar, bem como temos outros espaços que necessitam de manutenção, para então serem ativados.

\section{2) MODIFICAÇÕES E AÇÕES QUE INTERFEREM NA ESTRUTURA DA ESCOLA,} REALIZADAS NO ANO LETIVO DE 2009 E INÍCIO DE 2010:

- Modificação das salas do EJA para sala de educação física

- Sala de Psicomotricidade passou a sala de aula da EJA

- Ante sala do auditório é utilizada como sala de educação artística e leitura

- Sala de atendimento aos alunos com déficit intelectual passou a ser sala de aula para ás áreas de TGD

- Uma sala destinada a Equipe passou a ser uma sala da precoce (sala de DV)

- A ludoteca passou a ser sala de arte e leitura do atendimento complementar.

- Uma sala de DMu passa a ser sala de Informática

- Espaço de projeção do auditório passou a ser espaço para o professor do SOT

- Uma sala de aula de atendimento aos alunos TGD foi reservado para sala das auxiliares em 2009 e conforme a necessidade de 2010 a sala volta a ser sala de aula de TGD

- Antiga sala das auxiliares se transformou em depósito de bens (patrimônios sem uso). Essa sala oferecia risco aos profissionais, por isso ser usada como depósito. Tal sala passou por pequena reestruturação e voltou a ser espaço para os auxiliares 
- Uma sala foi estruturada como sala de empréstimo, nessa fica responsável uma professora readaptada para emprestar, registrar e resgatar sons portáteis, DVD, fitas, CDs, livros.

\section{3- NECESSIDADES IMEDIATAS E FUTURAS}

- Reforma e cobertura na piscina grande, transformando-a em duas e com altura condizente a orientação dos professores de educação física do Centro,

- Trocar os espelhos das salas de aula;

- Manutenção da quadra poliesportiva,

- Cobertura da quadra;

- Pintura, manutenção e reforma, conforme as necessidades em todo o espaço físico da Unidade;

- Instalar grades em todas as janelas

- Instalar suportes de sons nas salas de aula e disponibilizar um som para cada sala

- Ouvir e buscar atender as necessidades e opiniões diversas (comunidade, servidores, professores, direção e alunos) para efetivação do projeto, visando o melhor funcionamento da instituição em todos os seus aspectos (pedagógico, político e organizacional).

- Adaptação dos banheiros para cadeirantes;

- Portões nas portas das salas que não foram contempladas;

- Nas salas de educação física, para favorecer a ventilação e utilização de outros espaços, abrir uma porta.

- Reestruturação, reforma e cobertura das piscinas (educação precoce e piscina grande da escola) sendo aquecidas e com espaço melhores divididos e aproveitáveis, arredondar as bordas, fechar laterais, criar acesso ao banheiro, a criação de um trocador para os alunos.

- Espelho completo para uma das laterais das salas de bebês (ed. Precoce).

- Mobiliário adequado para cada sala/atendimento, principalmente para os alunos de 0 à 6 anos de idade

- Rampa nos acessos do parquinho infantil para cadeirantes 
- Lanche adequado e específico à necessidade de nossos educandos, dando atenção para as crianças de 0 a 3 anos e os alunos que não conseguem ou não podem mastigar

- Cadeiras de rodas menores para as crianças que apresentam pequeno porte físico e as crianças de 0 à 6 anos

- Laboratório de informática para todos os alunos

- Escadas apropriadas nas piscinas;

- Sala de primeiros socorros com recursos adequados

- Buscar a participação efetiva dos pais na elaboração e execução do PPP;

- Viabilizar o transporte público para crianças consideradas de risco no período em que freqüentar os atendimentos (carteira de passe livre provisória);

- Viabilizar a substituição dos professores para que os alunos não sejam prejudicados pedagogicamente (mil horas/aula em 200 dias letivos conforme ás especificidade de cada área de atendimento), então acionar o banco de reservas;

- Discentes: Freqüência, higiene pessoal, pontualidade e participação nas atividades propostas pela Unicidade.

- Pais: Favorecer a freqüência dos alunos, justificar as ausências dos alunos, informar sobre acontecimentos relacionados aos alunos que possam interferir no trabalho pedagógico, valorizar o trabalho realizado, seguir as orientações recebidas dos profissionais para o desenvolvimento do aluno, participação efetiva nas atividades propostas pela escola e no trabalho aos pais oferecido pelo programa de educação precoce e nos projetos oferecidos por parceiros

- Que todos os pais/acompanhantes aguardem os alunos no banco de entrada da escola, assim evitando que acompanhantes e visitantes possam ficar passeando na escola,

- Trabalhar com datas que realmente possam favorecer uma interação entre os segmentos da escola com o intuito da socialização e desenvolvimento do nosso aluno.

- Formação de cadastro de rede de apoio junto ao comércio local com o intuito de agilizar e facilitar a realização dos eventos (passeios, festas);

- Quando dos eventos, formar equipes de apoio, cada qual com suas devidas responsabilidades (ornamentação, confecção de alimentos, etc) Tais equipes 
deverão ser compostas por todos os seguimentos da escola (direção, professores, auxiliares e pais);

- Parcerias que possam oferecer ajudas diversas para o melhor e mais rápido desenvolvimento das atividades pedagógicas as quais necessitamos de apoio imediato que a SEEDF não disponibiliza.

- Reforma do parquinho (brinquedos, piso ou areia adequados, cobertura).

\section{VII - ORGANIZAÇÃO CURRICULAR}

Conforme registros constantes nas Orientações Curriculares da Educação Básica - Ensino Fundamental - Séries e Anos Iniciais da Secretaria de Estado de Educação do Distrito Federal, o objetivo principal da educação é envolver o aluno em contexto que favoreça, oportunizem e proporcionem condições para o exercício da cidadania em consonância com a socialização em espaço escolar, envolvidos no direcionamento da aquisição de conhecimentos e o desenvolver de competências, habilidades, valores e atitudes.

O Centro de Ensino Especial 02 de Ceilândia trabalha com o currículo da educação básica, a saber: educação infantil e da educação de Jovens e adultos. Além de respeitar o limite dos nossos alunos, realizamos, quando necessário, às adaptações curriculares e ou trabalhamos com o currículo funcional, isso depende da área de atendimento e necessidade dos discentes.

Nosso fazer pedagógico está aliado a princípios que envolvem a criatividade e a diversidade artística e cultural, essencial à formação integral do educando. Esse permeia a organização curricular, as relações interpessoais, o planejamento e avaliação.

Para melhor operacionalização do mesmo são realizadas avaliações e estudo de caso periodicamente ou quando se faz necessário. Em seguida vislumbra-se a melhor forma de realizar as adaptações curriculares, apropriando-as às especificidades de cada um de nossos alunos. Adequamos os nossos atendimentos 
pedagógicos considerando o nível de desenvolvimento e o quadro físico e mental do aluno.

Com vistas à atuação e aplicabilidade da interdisciplinaridade e contextualização dos conteúdos, optamos por trabalhar com metodologias diversificadas que contemplem a pluralidade de teorias pedagógicas, levando em consideração que o ensino especial necessita de uma abordagem diferenciada que favoreça o desenvolvimento do aluno.

Fazemos questão de ressaltar a importância das atividades físicas, artísticas, culturais e lúdicas, as quais possibilitam que o corpo docente tenha meio variado e favorável para atuar de forma mais dinâmica a contribuir para o sucesso do nosso educando no campo pedagógico, esse não se restringe à leitura e escrita conforme os moldes tradicionais.

\section{VIII- Fundamentação da Proposta Curricular}

Este Centro entende a Educação Especial não como um sistema paralelo ao sistema regular, mas sim, como uma modalidade de educação que permeia todos os níveis educacionais. Desse modo, sua proposta de atendimento é, à medida do possível, seguir as orientações do currículo da educação básica, com as devidas adaptações, conforme nos assegura a LDB 9394/96 em seu capítulo V e a Resolução n. ${ }^{\circ} 1$ de 26 de Agosto de 2003 do CEDF.

Os ANEEs apresentam características específicas resultante de viscosidade genética, portanto, muitas vezes é difícil adequar a matriz curricular a alguns atendimentos tais como Deficiência Múltiplas (DMu) e Transtorno Global do Desenvolvimento (TGD), os quais requerem procedimentos muito específicos. Os atendimentos são construídos baseados no conhecimento técnico dos professores para atender às especificidades da clientela, assim, aplicamos o que diz os PCNs Adaptações Curriculares para Educação Especial:

Educação Especial - Modalidade da educação escolar. Processo educacional definido em proposta pedagógica, assegurando um conjunto de recursos e serviços educacionais especiais, organizados institucionalmente 
para apoiar, complementar, suplementar e, em alguns casos, subsistir os serviços educacionais comuns, de modo a garantir a educação escolar e promover o desenvolvimento das potencialidades dos educandos que apresentam necessidades educativas especiais da educação básica. (BRASIL, 1999, p.21)

Dada à especificidade da clientela atendida, é de fundamental importância que o Centro complemente seu quadro de profissionais com fonoaudiólogo, fisioterapeuta, assistente social, ou que se firmem convênios com entidades especificadas.

A comunidade escolar é carente, em sua grande maioria, e muitas vezes nos deparamos com situações delicadas que influenciam no processo pedagógico, a saber; alguns problemas familiares, pouca contribuição dos pais para compra de materiais dos alunos e para a escola (eventos), pouca informação sobre as necessidades especiais e sobre como auxiliar na educação dos filhos, falta de recurso financeiro que impossibilitam a urgência na entrega de atestados e laudos (a rede pública de saúde não tem suprido tais necessidades), ruptura do trabalho de higienização por falta de recursos (diversos).

A participação, ainda, se restringe as reuniões pedagógicas e festas. Não há participação efetiva em todos os momentos propostos pela escola. Tendo em vista a diversidade da comunidade escolar que é atendida no Centro, procuramos organizálas por modalidades e a partir daí buscar o quê e como trabalhar de forma a propiciar o desenvolvimento dos alunos com necessidades educativas especiais. As questões metodológicas são discutidas por área, desse modo, os atendimentos estão organizados da seguinte forma:

- Educação Precoce: Programa de Educação Precoce atende crianças de 0 a 3 anos e 11 meses de idade com suspeita de qualquer atraso no desenvolvimento ou deficiência comprovada. As turmas são formadas de doze a dezoito alunos. Os alunos recebem de um a três atendimentos de quarenta e cinco minutos, de uma a três vezes por semana, conforme a necessidade dos educandos. Esses podem acontecer em dias alternados, com professores de atividades e educação física. Os horários dos alunos são organizados conforme suas necessidades. Quanto à organização curricular, a educação 
precoce fundamenta-se nos pressupostos teóricos de Vygostsky, Piaget e Wallon acerca do desenvolvimento e da aprendizagem. As atividades lúdicas constituem 0 berço obrigatório das atividades intelectuais e sociais superiores, sendo por isso indispensável ás práticas educativas. O processo avaliativo é de competência dos profissionais envolvidos no programa e com foco no desenvolvimento global do educando. Essa é realizada por observações diárias, preenchimento da ficha evolutiva (cópia em anexo) e do relatório semestral. A educação física, nesta área, visa o processo de desenvolvimento motor, principalmente no primeiro ano, utilizando área da piscina, espaço de em sala de aula e os demais recursos da escola para o desenvolvimento psicomotor. A partir dos dois anos de idade é trabalhado a interação social e a autonomia. Em EF é obrigatório a apresentação do atestado médico.

- DMU: Os alunos desta área são atendidos por professores de atividades, artes e leitura e educação física. Em artes e leitura o atendimento ocorre uma vez por semana com uma hora de duração. Em educação física a grade horária é de cinqüenta minutos, os alunos podem receber de um a três atendimentos, conforme as necessidades do educando. $\mathrm{O}$ atendimento $\mathrm{DMu}$ acontece em três formas de grades diferenciadas, visando o melhor atendimento para o discente. Assim temos enturmação em currículo adaptado (no máximo três alunos, com cinco horas aula diária de segunda a sexta feira, podendo em alguns casos haver turmas onde haja aluno que necessite de horário reduzido), turmas atendidas em forma de rodízio ( alunos que pelas limitações sensório-motora, psicológica e clínica não suportam grade horária completa, assim são atendidos individualmente - de duas a cinco vezes por semana - de duas horas e trinta minutos a cinco horas aula, nesse quadro a turma é formada de três a cinco alunos, dependendo do grau de limitação e necessidade do aluno). O alunos do DMu que não se enquadram no perfil de atendimento de currículo adaptado recebem atendimento escolar com base na orientação curricular constante no currículo funcional, ele apresenta como perspectiva a capacitação dos alunos nas áreas de desenvolvimento, 
visando a inclusão social, porém não abortamos em hipótese alguma a possibilidade de trabalhar o currículo adaptado, essa situação poderá acontecer conforme o desenvolvimento do aluno e a necessidade educacional que o mesmo apresentar. Mediante especificidade de alguns alunos, em algumas turmas do DMu é aplicado o currículo adaptado que flexibiliza a prática educacional para propiciar o progresso em função de suas possibilidades e diferenças individuais, com intuito de inseri-los em turma inclusiva no Ensino Regular. Quanto à organização pedagógica o trabalho desenvolvido procura atender as particularidades dos alunos, sendo revisto e ajustado bimestralmente, mediante a necessidade e o desenvolvimento dos discentes. $\mathrm{O}$ foco destes atendimentos é oferecer ao aluno com deficiência múltipla, oportunidades educacionais ás suas características específicas, buscando-se o desenvolvimento máximo de sua potencialidades e visando torná-los independente e integrado à comunidade.

- DI: Classes de alunos com deficiência intelectual, atende de 04 a 08 alunos por turma. O funcionamento desta área corresponde ao atendimento referente à educação infantil/currículo adaptado. Os alunos têm 5 horas de atendimento com professores de atividades. As aulas de educação física podem acontecer de duas a três vezes por semana, em dias alternados. Os alunos desta área também recebem atendimentos na sala de leitura e artes. Nesta área estão os alunos com maiores perspectivas de inclusão, para tanto recebem acompanhamento mais intensivo da equipe de apóio a aprendizagem no intuito de acompanhar minuciosamente 0 processo de desenvolvimento e encaminhá-los para a rede regular de ensino conforme suas respectivas necessidades. O processo avaliativo é baseado na avaliação formativa e somativa, além dos registros bimestrais, em estudo de caso, teste da psicogênese e na avaliação do desenvolvimento global do aluno. Vale registrar que em 2010 não tivemos turmas nesta área de atendimento educacional.

- Transtorno Global do Desenvolvimento: atendimento aos alunos que apresentam comportamento típico de síndromes e quadros psicológicos neurológicos que ocasionam atraso no desenvolvimento e 
prejuízo no relacionamento social, requerendo assim atendimento educacional especializado. Os alunos, dadas as suas características específicas, são atendidos individualmente (quando justificado tal necessidade), ou turma formada por dois alunos (0 à 14 anos) e ainda em turma de rodízio, formada de três a cinco alunos (acima de 14 anos) onde os alunos recebem as aulas em dias alternados e ou horários reduzidos, porém o professor, em momento algum atende mais que dois alunos. $\mathrm{O}$ atendimento é de 5 horas diárias. As aulas de educação física podem acontecer de duas a três vezes por semana em dias alternados. Nesta área temos educandos atendido pelo currículo funcional e adaptado. A organização pedagógica é realizada com as orientações registradas na modulação/2010. Almeja-se que todos os professores desta área tenham formação na área de TGD. A avaliação nesta área objetiva possibilitar maior agilidade no processo de aprendizagem através de: acompanhamento diário dos objetivos propostos para cada aluno, reestruturação constante do planejamento (substituição dos objetivos alcançados), aplicação da escala PORTAGE (cópia em anexo) ao final de cada ano letivo (quando necessário uma no início do ano letivo e outra no fim). Ao indicar os espaços de atendimentos dos alunos com TGD deve-se observar as necessidades dos alunos quanto a localização da sala (próximo ao banheiro e longe dos portões de acesso à escola), mobiliário da sala e horários. Os professores consideram importante realizar um passeio por mês com objetivo de trabalhar a socialização e interação com o outro. Esses passeios são de curta duração, no máximo de três horas, observando e respeitando a tolerância do aluno. Em educação física prima-se por atendimentos individualizados, pois os educandos apresentam ritmo, desejos, potenciais, interesses bem individualizados. Eles recebem de dois a três atendimentos em EF, por semana.

- Oficinas Pedagógicas: Os alunos permanecem na escola por 5 horas diárias, sendo atendidos em oficinas pré-profissionalizantes de acordo com as suas habilidades. A turma é formada de 12 a 16 alunos. Nessa área, buscamos, com respaldo da Divisão de Educação Especial, trabalhar com a modulação mínima, caso seja dado indeferido 
solicitamos trabalhar no máximo com 18 alunos, tendo em vista que nossas salas de aula não oferecem espaço físico suficiente para atendermos, com qualidade, a modulação máxima e também não temos mobília condizente, assim o grau de limitações de nossos educandos é bastante agravada, por esse motivo não trabalharmos com a modulação máxima. È válido informar que em nossas oficinas os alunos estão em contato direto com objetos e ambiente que oferecem riscos (tesoura, agulhas variadas, lixas, facas, vidros, fogo, utensílios de horta...) sendo esses os principais e preocupantes motivos para menor número de aluno por sala, com tal possibilidade, o regente tem maior liberdade para trabalhar e oferecer maior atenção a cada educando. Nesta área a avaliação é formativa, levando em consideração a participação, envolvimento e produção do aluno. $O$ professor do SOT terá estreita relação com está área de atendimento para favorecer os educandos que possam ser encaminhados ao mercado de trabalho.

- Classes do EJA: turmas de 12 a 32. Estes recebem atendimento adaptado para alfabetização de jovens e adultos da educação especial. $O$ atendimento acontece cinco vezes por semana com carga horária de cinco horas diárias. Em educação física, repete-se conforme os demais atendimentos. No ano letivo de 2009 e 2010 atendemos o primeiro segmento da EJA. Os alunos desta área recebem atendimento na sala de leitura e artes e atendimento em oficina do "Papel reciclado". Essa oficina é oferecida exclusivamente aos alunos da EJA. O processo avaliativo ocorre de forma formativa e somativa. A somativa dar-se principalmente em respeito às solicitações da coordenação da EJA da Divisão do Ensino Especial. Essa área educacional, a partir de 2010 é também atendida pelo o professor que realiza a atividade do SOT.

- Atendimento Complementar: Atende alunos das escolas pertecentes a Região Norte de Ceilândia, num total de140 educandos com diagnósticos variados. Cada professor atende de trinta a sessenta educandos. Esses alunos recebem atendimentos em salas temáticas de artes e leitura, informática, horta e educação física. Além dos atendimentos aos alunos, há programação de oficinas e palestras para 
os professores do ensino regular com vistas apoiar o processo inclusivo.

- Serviço de Orientação Profissional (SOT): Realiza trabalho com os alunos do Centro e os alunos incluídos na perspectiva de encaminhálos ao mercado de trabalho. O profissional desta área faz trabalho em parceria com o coordenador de EJA e as professoras de oficinas.

Amparados no capítulo V da LDB 9394/96 em seu art. 59 inciso I, que assegura organização específica aos educandos com necessidades educativas especiais, alguns alunos, dado ao comprometimento, possuem o horário diferenciado baseado em Estudo de Caso e apoio do Conselho Escolar (quando necessário) e dos pais.

Ainda conforme o capítulo supracitado, complementado pelo artigo 26 § $3^{\circ}$ a educação física é integrada a proposta pedagógica da escola, ajustando-se às faixas etárias e às condições da população escolar. Portanto, os professores, mesmo sendo de áreas específicas atenderão de acordo com o horário dos professores de atividades, ou seja, 25 horas de regência e 15 horas conforme prevê a portaria vigente.

\section{IX-FUNDAMENTOS NORTEADORES DA PRÁTICA EDUCATIVA}

O mundo vive em constantes transformações, não devemos estar e ficar alheios, portanto há busca permanente do aprendizado, objetivando oportunizar ao educando meios para viver, conviver e ser ativo na sociedade.

Temos consciência que o ser humano é um ser relacional, isto é, vive e se desenvolve conforme o seu meio, então constrói a si mesmo ao longo da vida: vivenciado, agindo, praticando, optando, enfrentando possibilidades e executandoas. Portanto não podemos ignorar essa importante relação do ser humano. Dentro desta visão faz sentido estabelecermos elos entre o processo educativo unido a realidade do nosso discente.

Os fins e princípios norteadores estabelecidos pelo Centro de Ensino Especial 02 de Ceilândia para orientar a prática educativa foram definidos em consonância com as regulamentações da Constituição Federal de 1998 e as Leis que amparam a 
educação aliados a momentos de estudos e reflexão de todo grupo escolar ao encontro do eixo que seja condizente com as nossas necessidades e que atenda a demanda educacional em todos os princípios em que está apoiado a educação. Diante o exposto, todo grupo opta pela linha de trabalho com vistas ao desenvolvimento de habilidades e competências a partir de vivências relevantes à realidade da comunidade escolar, sob o eixo: EU COMO SER SOCIAL. Este "EU" refere-se ao aluno.

O eixo estabelecido visa enfocar o desenvolvimento humano de forma harmoniosa em dimensões físicas, sociais, emocionais, culturais, políticas e educacionais. Sendo pautado em princípios éticos da autonomia, responsabilidade, solidariedade e do respeito ao bem comum norteadores da vida cidadã. Assim, a ação escolar centrará as ações no aluno e na aprendizagem como um processo de construção e formação do ser humano, propiciando momentos e ações que possibilitem atitudes e princípios de valores universais: de amor, de companheirismo, da não descriminação, de responsabilidade, fraternidade, honestidade, igualdade, justiça, liberdade, solidariedade, tolerância, verdade e amizade.

Neste quadro a inclusão esta fundada na dimensão sócio-cultural, pois procura enfatizar $o$ apoio às dificuldades e acolher as necessidades dessas pessoas. Diante tal temática, a proposta buscará envolver toda comunidade em uma gama de comportamentos que devem enfatizar o apoio ao encontro de vencer as dificuldades e acolher as necessidades dessas pessoas.

Nosso papel de educadores, no tocante ao sistema educacional, dentre outras perspectivas, preconiza a atenção à diversidade da comunidade escolar, considerando não só a capacidade/desenvolvimento intelectual, bem como interesses e motivações que contemplem áreas individuais, econômicas, sociais e culturais do educando.

Consideramos ainda fundamentações antropológicas, filosóficas, psicológicas e histórico-social que contribuam positivamente para um trabalho legal e produtivo no ponto de vista educacional, além dos subsídios resultantes das discussões, debates e reflexões de toda comunidade escolar no intuito de melhor 
elaborarmos a proposta pedagógica compatível com as nossas necessidades e desafios do mundo moderno. Assim, com base em nosso eixo norteador: "Eu Como Ser Social”, trabalharemos com a visão pedagógica abaixo:

- A equipe do Centro de Ensino Especial 02 de Ceilândia entende a escola como um espaço polissêmico e multidimensional, no qual diversos sentidos e significados são construídos diariamente. E para tanto, numa relação diária e dinâmica vamos construindo a nossa identidade;

- A educação é entendida como um processo de construção e transformação do indivíduo para sua atuação na sociedade, é complexa e dinâmica, estando intimamente ligada ao contexto no qual está inserida, assim faz-se necessário efetivo trabalho a partir da realidade da comunidade, então, planejar as ações;

- A educação Básica é percebida como direito inalienável do ser humano em qualquer idade, independente das limitações intelectuais, sociais e econômicas;

- A educação deve possibilitar e oportunizar o desenvolvimento humano harmonioso em todas as dimensões;

- Toda comunidade escolar deve primar pela igualdade, liberdade e fraternidade, reconhecendo e respeitando o pluralismo em todos os âmbitos;

- As atividades de expressão corporal, social, experiências em espaços múltiplos e interação com manifestações culturais e de lazer fazem parte do contexto educacional;

- O bem comum em espaço escolar se baseará em princípios éticos, de responsabilidade, solidariedade, cidadania, igualdade, justiça, equidade essenciais à formação integral do aluno;

- A família é vista como corpo primordial para melhor promover o processo educativo em parceria com o corpo docente;

- Orientar a família quanto à realização de atividades pedagógicas e sua importância para o desenvolvimento da criança;

- Desenvolver a partir do de temas: Eu (identidade), higiene pessoal e ambiental e cuidados com os bens naturais; 
- O grupo de professores, auxiliares, alunos e pais/ responsáveis pelos educandos trabalham com o intuito de buscar a melhor possibilidade para 0 desenvolvimento global de todos que constituem a comunidade escolar, valorizando cada segmento em sua diversidade;

- Todo grupo escolar busca em seu trabalho otimizar recursos que propiciem melhora na qualidade de ensino por meio da criatividade, espírito de iniciativa e principalmente um trabalho coletivo, levando o aluno com necessidades educativas especiais a conhecer outros ambientes, integrar-se cada vez mais na sociedade, além de criar estratégias para uma educação especial de qualidade.

- A dinâmica do meio é atribuída grande importância, partindo da possibilidade de vivenciar novas e reais situações, que resultarão em mais conhecimentos, percepção de causa e efeito, identificação, associações, dentre outras conquistas. Esse processo respeita a necessidade de planejamento e seus devidos objetivos dentro da visão coerente e sistemática de estímulos.

- A ação pedagógica enfatiza procedimentos capazes de promover a melhoria da qualidade de vida e o exercício da cidadania. É realizado trabalho de forma coletiva, fazendo da escola um espaço efetivo de discussão e formação continuada.

\section{X- AVALIAÇÕES}

O processo avaliativo deverá ocorrer de forma dinâmica, considerando tanto o conhecimento prévio quanto o nível atual de desenvolvimento do aluno e perceber as possibilidades de aprendizagens futuras, configurando ação pedagógica processual e formativa que analisa o desempenho do aluno em relação ao seu progresso individual, prevalecendo na avaliação os aspectos qualitativos que indiquem as intervenções pedagógicas do docente. Buscamos perceber os avanços dos alunos para orientar a prática educativa, de modo que o desenvolvimento ocorra da melhor forma possível. A avaliação é processual e contínua, observando o 
desenvolvimento global do aluno, buscando subsídios para o constante repensar das práticas pedagógicas.

De forma geral e respeitando os registros já citados (por área), os instrumentos de avaliação baseiam-se na observação e acompanhamento das atividades individuais e coletivas. Esta é realizada conforme as orientações da LDB 9394/96 e da Resolução 1 de 26 de agosto de 2003 do Conselho de Educação do Distrito Federal, ou seja, os aspectos qualitativos sobrepõe-se aos quantitativos, sendo entendida como um processo contínuo e cumulativo realizado no decorrer do ano letivo.

Em nossa visão, avaliar é buscar subsídios para a prática docente. Ela nos auxilia na verificação da aprendizagem, demonstra a necessidade na manutenção; definição ou redefinição de metas e objetivos e possibilita corrigir falhas e reforçamos os aspectos positivos.

Este processo não deve se restringir apenas ao aspecto cognitivo, mas proporcionar uma análise mais ampla da aprendizagem, sendo elaborados para evidenciar o desenvolvimento das competências e habilidades. Os resultados das nossas avaliações são registrados em forma de relatório semestralmente.

No Centro, a avaliação tem caráter diagnóstico, contínuo, cumulativo, formativo e sistemático, onde são percebidas as potencialidades e a busca da superação das dificuldades/falhas individuais e em grupo que possam interferir no processo educativo.

O processo avaliativo norteia e exerce papel essencial no contexto escolar. No Centro de Ensino Especial, o mesmo também é bastante importante, porém o processo avaliativo é amparado e focaliza suas diretrizes nas adaptações curriculares.

Os aspectos avaliados englobam o desenvolvimento sócio-emocional, psicomotor, intelectual, a formação de hábitos e atitudes, aquisição de habilidades e o domínio com tais, a superação de dificuldades e das limitações, bem como a busca por soluções em situações a serem resolvidas. 
Com o processo avaliativo nos deparamos com resultados que apóiam a dinâmica educativa, pois em seu desfecho encontramos meios para alcançarmos novos objetivos e reforçarmos os que ainda precisam ser trabalhados e superados, também permite a constatação dos avanços obtidos.

A avaliação apresenta-se como o mais abrangente e importante fator de aperfeiçoamento do processo educativo. Ultrapassa a simples aferição do conhecimento adquirido pelos alunos, apontando também, as falhas do ensino oferecido. Todo trabalho pedagógico é acompanhado pela direção, coordenação, supervisão e orientação pedagógica.

Abortado a concepção de buscar certos e errados, vencedores e perdedores ou momento de acusações e simples constatações, em caráter ordinário, realizamos avaliação de todo corpo docente, técnico e administrativo em forma de reflexões.

Esses momentos acontecem bimestralmente, envolvendo todos os servidores. Em primeira oportunidade há uma sensibilização/socialização por parte da direção da escola com todos servidores. Logo depois a direção expõe o todo, sem enfatizar o certo ou errado, dando a oportunidade de esclarecimento de dúvidas, então o grupo escolar é convidado a se dividirem em pequenos grupos, onde é realizado uma avaliação descritiva, seguindo orientações que envolva todos os segmentos. O próximo passo é a participação individual de cada servidor, respondendo um questionário objetivo que engloba todos os segmentos.

O resultado das avaliações descritivas e objetivas são tabuladas e apresentadas ao grupo, detectando os pontos negativos e positivos de nosso fazer pedagógico e interacional, como também traça o perfil dos profissionais, desde relação interpessoal ao contexto profissional.

No tocante a avaliação dos alunos, adotaremos a aplicação contínua do Teste da Psicogênese da leitura e escrita e da Escala Portage além de ficha avaliativa a ser elaborada pelo grupo de professores e coordenação, respeitando idade e área de atendimento.

Ao longo do ano também realizamos conselhos de classes, com características de estudo de caso, envolvendo professores, coordenação, 
supervisora pedagógica, orientadora e a equipe de apoio à aprendizagem. Conforme solicitação dos professores, montaremos um cronograma para estudos de caso correspondente às necessidades dos alunos.

\section{XI- AMBIENTE EDUCATIVO}

Ao longo da história desta instituição, houve alguns eventos que merecem ser destacados:

- Circuito pedagógico em 1999 e 2001: exposições das oficinas pedagógicas, apresentação cultural.

- Participação do Encontro Aprendendo com as Diferenças nos anos de 1999 e 2000 com exposição das oficinas pedagógicas.

- Participações em competições oficiais da Secretaria de Educação e do Calendário Esportivo da cidade.

- Participação na Feira do Livro do Centro de Ensino Especial 01 de Taguatinga com apresentação artística.

- Festival Recreativo Especial de Ceilândia, no qual houve a participação do Centro de Ensino Especial 01 de Ceilândia, nos anos de 2001 a 2008 e com o CEE de Brazlândia e APAED no ano de 2007, 2008 e 2009

- Participação nos Jogos da Primavera em 2005 e 2007.

- Realização de festas nas principais datas comemorativas.

- Feira Cultural Especial de Ceilândia nos anos de 2002 à 2009. Acontecerá em 2010

- Ornamentação da DREC em dadas comemorativas, atendendo a solicitação da Chefia da Regional;

- Participação da semana de Arte, organizada pela DREC no ano de 2007;

- Desfile pelo aniversário de Ceilândia e do Setor "O" nos anos de 2004, 2006, 2007, 2008, 2009 e participaremos em 2010.

- Caminhada pelo Meio Ambiente no ano de 2007, 2008, 2009 e se repetirá em 2010.

- Festa da Família nos anos de 2005 a 2009, programada a acontecer em 2010. 
XII- CORPO TÉCNICO, DOCENTE, ADMINISTRATIVO E DE CONSERVAÇÃO E LIMPEZA

MODULAÇÃO - 2010

1 - SERVIDORES EM CARGO COMISSIONADO:

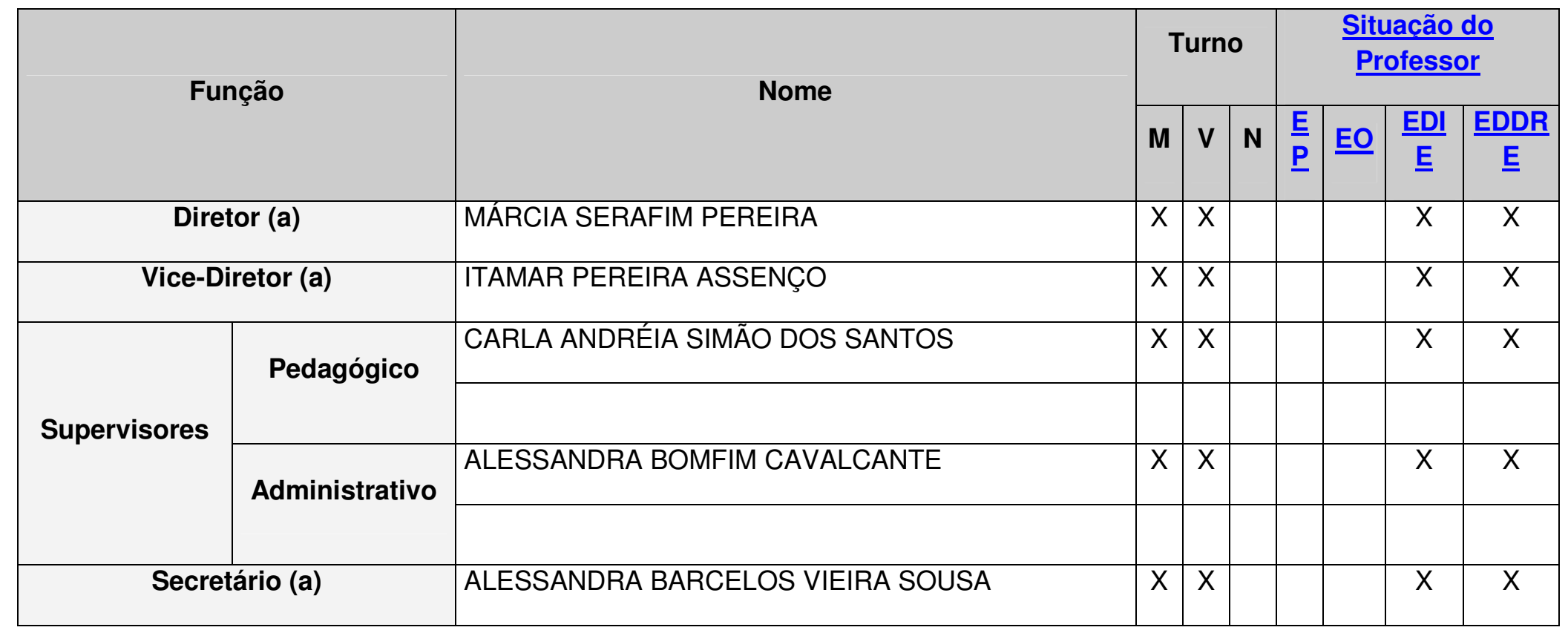




\begin{tabular}{|c|c|c|c|c|c|c|c|c|c|c|}
\hline \multirow{2}{*}{ Nome } & \multirow{2}{*}{ Habilitação } & \multicolumn{3}{|c|}{ Turno } & \multicolumn{2}{|c|}{$\begin{array}{c}\text { Carga } \\
\text { Horária }\end{array}$} & \multicolumn{4}{|c|}{$\frac{\text { Situação do }}{\text { Professor }}$} \\
\hline & & $\mathbf{M}$ & $\mathbf{V}$ & $\mathbf{N}$ & $\begin{array}{c}20 \\
h\end{array}$ & $\begin{array}{c}40 \\
h\end{array}$ & $\begin{array}{l}E \\
P\end{array}$ & EO & $\begin{array}{c}\text { EDI } \\
\text { E }\end{array}$ & $\begin{array}{c}\text { EDDR } \\
\text { E }\end{array}$ \\
\hline SIMONE MAMEDE DE FRANÇA & ATIVIDADES & $\mathrm{X}$ & $\mathrm{X}$ & & & $\mathrm{X}$ & & & $\mathrm{X}$ & $\mathrm{X}$ \\
\hline LILIA BATISTA FELIX DA SILVA & ATIVIDADES & $\mathrm{X}$ & $\mathrm{X}$ & & & $\mathrm{X}$ & & & $\mathrm{X}$ & $\mathrm{X}$ \\
\hline ALBENIRA ROSA RODRIGUES SOEIRA & ATIVIDADES & $\mathrm{X}$ & $\mathrm{X}$ & & & $\mathrm{X}$ & & & $\mathrm{X}$ & $\mathrm{X}$ \\
\hline JOELMA DE OLIVEIRA MOURA & ATIVIDADES & $\mathrm{X}$ & $\mathrm{X}$ & & & $\mathrm{X}$ & & & $\mathrm{X}$ & $\mathrm{X}$ \\
\hline
\end{tabular}

\section{3 - SERVIC̣O ESPECIALIZADO DE APOIO À APRENDIZAGEM:}

\begin{tabular}{|c|c|c|c|c|c|c|c|c|c|c|}
\hline \multirow{2}{*}{ Nome } & \multirow{2}{*}{ Atuaccão / Habilitação } & \multicolumn{3}{|c|}{ Turno } & \multicolumn{2}{|c|}{$\begin{array}{c}\text { Carga } \\
\text { Horária }\end{array}$} & \multicolumn{4}{|c|}{$\frac{\text { Situaccão do }}{\text { Professor }}$} \\
\hline & & $\mathbf{M}$ & V & $\mathbf{N}$ & $\begin{array}{c}20 \\
h\end{array}$ & $40 \mathrm{~h}$ & $\begin{array}{l}\mathrm{E} \\
\mathrm{P}\end{array}$ & EO & $\begin{array}{c}\text { EDI } \\
\text { E }\end{array}$ & $\begin{array}{c}\text { EDDR } \\
\text { E }\end{array}$ \\
\hline MARLINDA FERREIRA DE LIMA NOGUEIRA & Pedagoga/Atividades & $\mathrm{X}$ & $\mathrm{X}$ & & & $\mathrm{X}$ & & & $\mathrm{X}$ & $\mathrm{X}$ \\
\hline LUZINETE MARIA SOUZA DAS CHAGAS & Psicológa/Português & $\mathrm{X}$ & $\mathrm{X}$ & & & $\mathrm{X}$ & & & $\mathrm{X}$ & $\mathrm{X}$ \\
\hline
\end{tabular}


4 - ESPECIALISTA DE EDUCAÇÃO BÁSICA (ORIENTADOR EDUCACIONAL):

\begin{tabular}{|c|c|c|c|c|c|c|c|c|c|}
\hline \multirow{2}{*}{ Nome } & \multicolumn{3}{|c|}{ Turno } & \multicolumn{2}{|c|}{$\begin{array}{c}\text { Carga } \\
\text { Horária }\end{array}$} & \multicolumn{4}{|c|}{$\frac{\text { Situação do }}{\text { Professor }}$} \\
\hline & $\mathbf{M}$ & V & $\mathbf{N}$ & $\begin{array}{c}20 \\
h\end{array}$ & $40 \mathrm{~h}$ & $\begin{array}{l}\mathbf{E} \\
\mathbf{P}\end{array}$ & EO & $\begin{array}{c}\text { EDI } \\
\text { E }\end{array}$ & $\begin{array}{c}\text { EDDR } \\
\mathrm{E}\end{array}$ \\
\hline MARIA NEVES DE B. LISBOA & $\mathrm{X}$ & $\mathrm{X}$ & & & $\mathrm{X}$ & & & $\mathrm{X}$ & $\mathrm{X}$ \\
\hline
\end{tabular}

\section{8 - PROFESSORES EM SALA DE LEITURA:}

\section{Projetos: LEITURA E ARTES}

\begin{tabular}{|c|c|c|c|c|c|c|c|c|c|c|c|}
\hline \multirow{2}{*}{ Nome } & \multirow{2}{*}{ Habilitacões } & \multicolumn{3}{|c|}{ Turno } & \multicolumn{2}{|c|}{$\begin{array}{c}\text { Carga } \\
\text { Horária }\end{array}$} & \multicolumn{5}{|c|}{ Situaccão do Professor } \\
\hline & & M & $\mathbf{V}$ & $\mathbf{N}$ & $\begin{array}{c}20 \\
h\end{array}$ & $\begin{array}{c}40 \\
\mathrm{~h}\end{array}$ & $\begin{array}{l}E \\
P\end{array}$ & EO & $\begin{array}{c}\text { EDI } \\
\text { E }\end{array}$ & $\begin{array}{c}\text { EDDR } \\
\mathrm{E}\end{array}$ & $\begin{array}{c}\text { Rea } \\
\text { d. }\end{array}$ \\
\hline JANAINA DA SILVA PINTO & ATIVIDADES & $\mathrm{X}$ & $\mathrm{X}$ & & & $\mathrm{X}$ & & & $\mathrm{X}$ & $\mathrm{X}$ & \\
\hline ANA LUCIA MORAIS DE ALMEIDA & ARTES & $\mathrm{X}$ & $\mathrm{X}$ & & & $\mathrm{X}$ & & & $\mathrm{X}$ & $\mathrm{X}$ & \\
\hline & & & & & & & & & & & \\
\hline & & & & & & & & & & & \\
\hline
\end{tabular}


9 - PROFESSORES COM LIMITAÇÃO DE ATIVIDADE (READAPTADOS):

\begin{tabular}{|c|c|c|c|c|c|c|c|}
\hline \multirow{2}{*}{ Nome } & \multirow{2}{*}{ Habilitacões } & \multirow{2}{*}{ Atividade Desenvolvida } & \multicolumn{3}{|c|}{ Turno } & \multicolumn{2}{|c|}{$\begin{array}{c}\text { Carga } \\
\text { Horária }\end{array}$} \\
\hline & & & $\mathbf{M}$ & $\mathbf{V}$ & $\mathbf{N}$ & $20 \mathrm{~h}$ & $40 \mathrm{~h}$ \\
\hline VALMIRA SURIANO - 080.008165/2002 & ATIVIDADES & $\begin{array}{c}\text { Apoio à Educação } \\
\text { Precoce }\end{array}$ & $x$ & $X$ & & & $X$ \\
\hline FLÁVIA FRANCO DE SOUZA - 080.003883/2004 & ATIVIDADES & Apoio à Direção & $\mathrm{X}$ & $\mathrm{X}$ & & & $\mathrm{X}$ \\
\hline ISAURA BARBOSA RODRIGUES - 080.005829/2004 & GEOGRAFIA & Apoio à Direção & $\mathrm{X}$ & $\mathrm{X}$ & & & $\mathrm{X}$ \\
\hline $\begin{array}{l}\text { MARCIA REGINA ASSIS NEIVA SARAIVA - } \\
\text { Aguardando publicação do Ato de Readaptação no } \\
\text { DODF }\end{array}$ & ATIVIDADES & Apoio à Direção & $x$ & $\mathrm{X}$ & & & $\mathrm{X}$ \\
\hline LIZ BETÂNIA AMORIM RODRIGUES - 080. & ATIVIDADES & Psicólogo & $\mathrm{X}$ & $\mathrm{X}$ & & & $\mathrm{X}$ \\
\hline
\end{tabular}


11 - PROFESSORES CID/GINÁSTICA NAS QUADRAS/SEGUNDO TEMPO/ESPORTE À MEIA-NOITE:

\begin{tabular}{|c|c|c|c|c|c|c|c|c|c|c|}
\hline \multirow{2}{*}{ Nome } & \multirow{2}{*}{ Atuação / Habilitação } & \multicolumn{3}{|c|}{ Turno } & \multicolumn{2}{|c|}{$\begin{array}{c}\text { Carga } \\
\text { Horária }\end{array}$} & \multicolumn{4}{|c|}{$\frac{\text { Situacão do }}{\text { Professor }}$} \\
\hline & & $\mathbf{M}$ & $\mathbf{V}$ & $\mathbf{N}$ & $\begin{array}{c}20 \\
h\end{array}$ & $40 \mathrm{~h}$ & $\begin{array}{l}E \\
P\end{array}$ & EO & $\begin{array}{c}\text { EDI } \\
\text { E }\end{array}$ & $\begin{array}{c}\text { EDDR } \\
\text { E }\end{array}$ \\
\hline PAULIPETERSON CANDIDO ALVIM & $\begin{array}{l}\text { EDUCAÇÃO } \\
\text { FISICA/CID }\end{array}$ & $x$ & $X$ & & & $X$ & $X$ & & & $X$ \\
\hline JOÃO PAULO BRITO COSTA & $\begin{array}{l}\text { EDUCAÇÃO } \\
\text { FISICA/CID }\end{array}$ & $x$ & $X$ & & & $X$ & $X$ & & & $X$ \\
\hline MÁRCIO GOMES DE OLIVEIRA & $\begin{array}{l}\text { EDUCAÇÃO } \\
\text { FISICA/CID }\end{array}$ & $\mathrm{X}$ & $X$ & & & $\mathrm{X}$ & & & $X$ & $\mathrm{X}$ \\
\hline
\end{tabular}


13 - PROFESSORES EXCEDENTES:

\begin{tabular}{|c|c|c|c|c|c|c|c|c|c|c|c|}
\hline \multirow{2}{*}{ Nome } & \multirow{2}{*}{ Habilitações } & \multirow{2}{*}{$\begin{array}{c}\text { Atividade } \\
\text { Desenvolvida }\end{array}$} & \multicolumn{3}{|c|}{ Turno } & \multicolumn{2}{|c|}{\begin{tabular}{|c|} 
Carga \\
Horária
\end{tabular}} & \multicolumn{4}{|c|}{$\frac{\text { Situacão do }}{\text { Professor }}$} \\
\hline & & & $\mathbf{M}$ & V & $\mathbf{N}$ & $\begin{array}{c}20 \\
\mathrm{~h}\end{array}$ & $\begin{array}{l}40 \\
h\end{array}$ & $\begin{array}{l}E \\
P\end{array}$ & EO & $\begin{array}{c}\text { EDI } \\
E\end{array}$ & $\begin{array}{c}\text { EDDR } \\
\text { E }\end{array}$ \\
\hline OTONE ALENCAR-LTS até 22/02/2010 & ATIVIDADES & ATIVIDADES & $\mathrm{X}$ & $\mathrm{X}$ & & & $\mathrm{X}$ & & & $\mathrm{X}$ & $\mathrm{X}$ \\
\hline FABIANA DE OLIVEIRA BRANDÃO & ATIVIDADES & ATIVIDADES & $\mathrm{X}$ & $\mathrm{X}$ & & & $\mathrm{x}$ & $\mathrm{X}$ & & & \\
\hline ZENOBIA DE OLIVEIRA BRANDÃO & ATIVIDADES & ATIVIDADES & $\mathrm{x}$ & $\mathrm{X}$ & & & $\mathrm{x}$ & $\mathrm{x}$ & & & $\mathrm{X}$ \\
\hline
\end{tabular}




\begin{tabular}{|l|l|}
\hline $\mathbf{N}^{\mathbf{0}}$ & Carreira assistência \\
\hline 01 & ADALCINO PEREIRA DA SILVA \\
\hline 02 & AILTON PEREIRA DOS SANTOS \\
\hline 03 & ALDEMYR BARBOSA ANA \\
\hline 04 & ALVINA MARIA DE JESUS NETA \\
\hline 05 & ANALDO GRACIANO DE SOUSA \\
\hline 06 & ANTÔNIA DE ARAUJO SANTANA \\
\hline 07 & ANTONIA PERES DE FARIAS \\
\hline 08 & AURORA GUEDES DE SENA \\
\hline 09 & DASDORES JOSÉ MARTINS \\
\hline 10 & EDUARDO DA MOTA \\
\hline 11 & FRANCISCO FERREIRA DA SILVA \\
\hline 12 & IVANILDO EPITÁCIO DE FREITAS \\
\hline 13 & JANIA MARIA GOMES \\
\hline 14 & JOCÉLIA FERREIRA RODRIGUES \\
\hline 15 & JORGE LUIZ DE SOUZA \\
\hline 16 & JOSÉ DE LISBOA NEVES ( Adm.) \\
\hline 17 & JOSÉ DONATO FERREIRA DURÃES \\
\hline 18 & FRANCISCO WASHINGTON RIBEIRO V. JUNIOR( monitor) \\
\hline 19 & JOVONETE M. JOCA PATRIOTA \\
\hline 20 & LUIZ SÉRGIO DOS SANTOS \\
\hline 21 & LUIZA VENTURA DA SILVA MATIAS \\
\hline 22 & MANOEL JOSÉ DE ALBUQUERQUE \\
\hline 23 & MARIA AUXILIADORA M. DE AZEVEDO. \\
\hline 24 & MARIA DO NASCIMENTO F. ALVES \\
\hline 25 & MARIA MARTINEZ CORDEIRO \\
\hline & \\
\hline 0.1
\end{tabular}


26 MARIA VITÓRIA DE LACERDA

27 MARILENE RIBEIRO NASCIMENTO

28 MARLI MEDEIROS VALADARES

30 ZAIDE APARECIDA DE OLIVEIRA

31 ZILDENE AMERICO DE OLIVEIRA

32 CECILIA BATISTA RAMOS (monitora)

33 ALESSANDRA B. CAVALCANTE (Adm.)

34 ALESSANDRA BARCELOS VIEIRA (Secretaria) 


\section{XII- PROJETOS ESPECIAIS}

Com o intuito de propiciar o desenvolvimento global do aluno com necessidades educativas especiais e a participação efetiva dos pais na escola, optou-se pela realização de diversos projetos no horário de retorno dos professores. Em 2010 não a observância em portaria quanto ao corpo docente em desenvolver projetos e atendimento aos alunos em horário de coordenação. Ainda assim, tentaremos junto ao grupo demonstrar a importância da contribuição de cada docente no processo de ensino / aprendizagem e de forma coletiva com vistas a perceber o quão importante foram tais momentos em 2009, diante isso decidir com o grupo a melhor maneira de manter tais projetos.

Desse modo, os professores, por área ou grupo de interesse se responsabilizam em trazer ao ambiente escolar uma atividade/ação que venha a beneficiar com nossa prática educacional. Hoje temos as seguintes temáticas:

- Dando Asas a Imaginação através do Teatro

- Iniciando as modalidades de esportes e o Atletismo Especial

- Cobra Banguela (leitura)

- Socialização de alunos com Necessidades Educativas Especiais por meio da Expressão Artística.

- Projeto de Dança Experimental

- Projeto de música/coral;

- Projeto de capoeira;

- Rádio na Escola

- Horta e Pomar

- Sou especial e faço parte (valores)

- Oficina de brinquedos pedagógicos

- Atendimento aos pais (atividades diversas)

- Qualidade de vida 
- Blog: Um Blog Especial (2010 e 2011)

- Contribuindo com a inclusão

Em momento proposto para participação dos pais e contribuição ao PPP, os pais/repensáveis fizeram as seguintes colocações:

1)Sugestões de temas para realização de palestras de interesses dos mesmos:

- Orientações de como lidar com crianças com necessidades educativas especiais

- Higiene bucal

- Acidentes domésticos

- Violência doméstica

- Palestra com os Conselheiros Tutelar

- Sexualidade voltada aos pais (como lidar com a sexualidade da criança),

- Higiene Pessoal,

- Saúde da Mulher,

- Palestras sobre síndromes e deficiências,

- Direitos da Pessoa com Necessidade Educativa Especial,

- Momento de oficinas para produção de brinquedos pedagógicos,

2) Pontos Positivos

- Organização na entrada da escola

- Uso do uniforme

- Os eventos e passeios

- Participação em alguns passeios

- A melhoria na qualidade do lanche e no momento de servir,

- As festas e os bazares

- A comemoração da semana da família

- Atendimento complementar na escola

- Monitoria no ônibus

- Contrato com a empresa Polo 
- Melhoria no atendimento com educador físico

- Melhoria no atendimento educacional

- As oficinas com a Justiça Comunitária

- A horta escolar

- A interação direção/professores/pais

- Qualidade nos eventos realizados

- A variedade de palestras,

- Atendimento da EJA no Centro

- Qualificação dos profissionais do Centro

- O evento "FREC"

3) Sugestões para melhorar os pontos que não foram positivos:

- Aumentar o número de atendimentos na equoterapia e demais atendimentos complementar

- Utilizar mais e melhor o espaço externo da escola

- Cobrir a quadra e a parte do parquinho

- Criar sistema para avisar com antecedência a falta/substituição do professor regente ( o pai nem sempre aceita que outro professor assuma o atendimento do aluno)

- Ativar a piscina de forma qualitativa (desativada desde 2003),

- Apresentação sistematizada por parte dos professores das atividades desenvolvidas pelos alunos nas reuniões de pais (realizamos reunião bimestralmente)

- Oferecer atendimento na área clínica (temos algumas parcerias na área odontológica e oftalmológica e descontos em consultas neurológicas)

- Separar os meninos das meninas no banheiro de mangueira,

- Que a biblioteca empreste materiais de estudo para os pais ou responsáveis

- Promover atendimento aos pais na sala de artes e leitura

- Insistir nos projetos de pais aos responsáveis que ficam na escola no horário de atendimento do aluno

- Oferecer lanche com mais frutas e verduras 
- Manter a semana da família com uma mini ação global

- Reforma do auditório

- Continuação do Projeto da Justiça Comunitária no matutino e vespertino

- Oportunizar momentos de exposições dos materiais produzidos pelas mães (justiça comunitária)

- Vestuário adequado para os professores que atendem na piscina da precoce (nos momentos de saída e entrada na área da piscina). Obs.: todos os professores usam roupão ao pegar ou entregar o aluno fora do espaço da piscina. 
XII- PLANO DE AÇÃO: ESTRATÉGIAS PARA IMPLEMENTAÇÃO DE RECURSOS FíSICOS, DIDÁTICO-METODOLÓGICO, PESSOAL, DOCENTE, DE SERVIÇOS ESPECIALIZADOS E DE APOIO.

\begin{tabular}{|c|c|c|c|c|c|c|c|}
\hline № & META & AÇÃO & JUSTIFICATIVA & DESENVOLVIMENTO & CRONOGRAMA & RECURSOS & RESPONSÁVEIS \\
\hline 01 & $\begin{array}{l}\text { Realizar atividades } \\
\text { de lazer }\end{array}$ & $\begin{array}{l}\text { Desenvolver atividades } \\
\text { recreativas de integração } \\
\text { e cooperação entre todos } \\
\text { os alunos e professores }\end{array}$ & $\begin{array}{l}\text { Para promover a interação } \\
\text { com o outro e com o meio, } \\
\text { visando à à inclusão } \\
\text { sociocultural, reconhecendo a } \\
\text { importância do respeito às } \\
\text { necessidades individuais. }\end{array}$ & $\begin{array}{l}\text { Projetos por áreas; } \\
\text { Peças teatrais; } \\
\text { Brincadeiras }\end{array}$ & Ano letivo & $\begin{array}{l}\text { Humanos: } \\
\qquad \begin{array}{ll}\text { * Professores e } \\
\text { alunos; }\end{array} \\
\begin{array}{ll}\text { Materiais de } \\
\text { física }\end{array} \\
\qquad \begin{array}{l}\text { Televisão } \\
\text { vídeo, } \\
\\
\text { DVD. }\end{array} \\
\end{array}$ & $\begin{array}{l}\text { Direção, } \\
\text { Professores, } \\
\text { coordenadores. }\end{array}$ \\
\hline 02 & $\begin{array}{l}\text { Utilizar a } \\
\text { expressão artística } \\
\text { como meio de } \\
\text { sociabilização do } \\
\text { aluno com os } \\
\text { colegas e escola, } \\
\text { e/ ou por meio da } \\
\text { música. }\end{array}$ & $\begin{array}{l}\text { Trabalhar o corpo como } \\
\text { forma de expressão e } \\
\text { desenvolvimento da } \\
\text { linguagem oral, gestual e } \\
\text { corporal, e propiciar } \\
\text { educação musical aos } \\
\text { alunos; }\end{array}$ & $\begin{array}{l}\text { Socializar e despertar o } \\
\text { interesse do aluno nas } \\
\text { atividades lúdicas }\end{array}$ & $\begin{array}{l}\text { Despertar } \\
\text { desprendimento da } \\
\text { imaginação e aluno por } \\
\text { criatividade do ala } \\
\text { meio de atividades } \\
\text { artísticas; leitura. } \\
\text { Trabalhar a música a } \\
\text { partir da apresentação } \\
\text { das letras e melodias } \\
\text { acompanhadas de } \\
\text { gestos e coreografias, } \\
\text { explorando, quando } \\
\text { possível à variação dos } \\
\text { estilos musicais. }\end{array}$ & Ano letivo & $\begin{array}{l}\text { Humanos: } \\
\text { Professores e alunos; } \\
\text { Materiais: } \\
\text { Aparelho de som. } \\
\text { CDs. } \\
\text { Fantasias. } \\
\text { Roupas usadas; } \\
\text { Papéis diversos; }\end{array}$ & $\begin{array}{l}\text { Professores } \\
\text { educação } \\
\text { artística } \\
\text { leitura }\end{array}$ \\
\hline
\end{tabular}




\begin{tabular}{|c|c|c|c|c|c|c|c|}
\hline 03 & $\begin{array}{l}\text { Realização de } \\
\text { Hora Cívica. }\end{array}$ & $\begin{array}{l}\text { Propiciar a construção da } \\
\text { cidadania }\end{array}$ & $\begin{array}{l}\text { Promover ato de cidadania } \\
\text { respeito e amor a pátria }\end{array}$ & $\begin{array}{l}\text { Realizar hora cívica por } \\
\text { área; } \\
\text { Hasteamento, } \\
\text { Arreamento da } \\
\text { bandeira; nos turnos } \\
\text { matutinos e vespertinos } \\
\text { sucessivamente. }\end{array}$ & Mensal & $\begin{array}{l}\text { Aparelho de som, } \\
\text { Microfone. } \\
* \quad \text { CDs. } \\
* \quad \text { Bandeiras do Brasil } \\
\text { e de Brasília. }\end{array}$ & $\begin{array}{l}\text { Direção, } \\
\text { coordenado } \\
\text { res, } \\
\text { professores } \\
\text {, }\end{array}$ \\
\hline 04 & $\begin{array}{l}\text { Efetivar o uso de } \\
\text { agendas }\end{array}$ & $\begin{array}{l}\text { Confeccionar ou comprar } \\
\text { agenda }\end{array}$ & $\begin{array}{l}\text { Acompanhar atividade extra } \\
\text { classe }\end{array}$ & $\begin{array}{l}\text { Anotações de recados } \\
\text { aos pais }\end{array}$ & Diário & Agenda; diário & $\begin{array}{l}\text { Professores } \\
\text { regentes }\end{array}$ \\
\hline 05 & $\begin{array}{l}\text { Oportunizar aos } \\
\text { pais } \\
\text { responsáveis } \\
\text { reuniões } \\
\text { pedagógicas para } \\
\text { maior participação } \\
\text { no processo } \\
\text { educativo. }\end{array}$ & $\begin{array}{l}\text { Montar cronograma de } \\
\text { reuniões. } \\
\text { Envolver os pais para } \\
\text { plena participação. }\end{array}$ & $\begin{array}{l}\text { Oferecer aos pais e } \\
\text { responsáveis oportunidades } \\
\text { de conhecimento no processo } \\
\text { educativos do seu filho }\end{array}$ & $\begin{array}{l}\text { Palestras; } \\
\text { Encontros periódicos se } \\
\text { necessário; }\end{array}$ & BIMESTRAL & $\begin{array}{l}\text { Humanos: } \\
\text { Equipe - EEAA/SOE } \\
\text { pais, e/ou responsáveis, } \\
\text { equipe diretiva. } \\
\text { Materiais: } \\
\text { * Cartazes } \\
* \text { Retroprojetor }\end{array}$ & $\begin{array}{l}\text { EEAA/SOE; } \\
\text { Equipe Diretiva }\end{array}$ \\
\hline
\end{tabular}




\begin{tabular}{|c|c|c|c|c|c|c|c|}
\hline 06 & $\begin{array}{l}\text { Realizar palestras } \\
\text { esclarecedoras } \\
\text { para professores e } \\
\text { pais. (Projeto de } \\
\text { Pais) }\end{array}$ & $\begin{array}{l}\text { Estabelecer contato } \\
\text { direto com profissionais } \\
\text { ligados à área para que } \\
\text { esses propiciem } \\
\text { momentos de ampliação } \\
\text { de conhecimento }\end{array}$ & $\begin{array}{l}\text { Melhoria nos atendimentos } \\
\text { oferecidos. }\end{array}$ & $\begin{array}{l}\text { Palestras; } \\
\text { Reuniões; }\end{array}$ & BIMESTRAL & $\begin{array}{l}\text { Humanos: } \\
\qquad \begin{array}{l}\text { Orientadora } \\
\text { educacional }\end{array} \\
\text { Materiais: } \\
* \text { Data show } \\
* \text { Retroprojetor. } \\
* \text { Lâminas. }\end{array}$ & $\begin{array}{l}\text { Orientadora } \\
\text { educacional }\end{array}$ \\
\hline 07 & $\begin{array}{l}\text { Realizar encontros } \\
\text { de estudos e } \\
\text { jornadas } \\
\text { pedagógicas com } \\
\text { certificados }\end{array}$ & $\begin{array}{l}\text { Compartilhar práticas } \\
\text { pedagógicas }\end{array}$ & $\begin{array}{lrr}\text { Montar grupos de } & \text { estudos } \\
\text { para melhoria } & \text { dos } \\
\text { atendimentos. } & \\
\end{array}$ & $\begin{array}{l}\text { Montar cronograma para } \\
\text { coordenações coletivas. }\end{array}$ & Ano letivo & 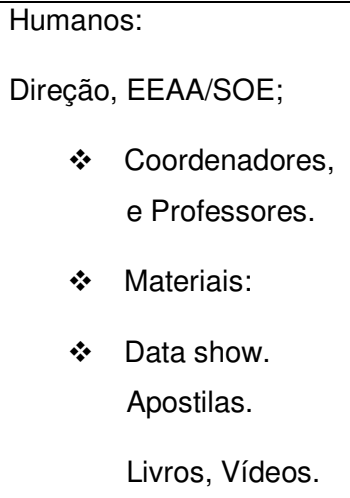 & $\begin{array}{l}\text { Coordenadores, } \\
\text { professores } \\
\text { EEAA/SOE. }\end{array}$ \\
\hline 08 & $\begin{array}{l}\text { Implantar projetos } \\
\text { especiais no } \\
\text { horário de retorno } \\
\text { do professor. }\end{array}$ & $\begin{array}{l}\text { Montar projetos em } \\
\text { diversas áreas. }\end{array}$ & $\begin{array}{lll}\text { Viabilizar } & 0 & \text { trabalho } \\
\text { pedagógico } & & \end{array}$ & $\begin{array}{l}\text { Selecionar alunos para } \\
\text { cadar projeto } \\
\text { desenvolvido. }\end{array}$ & Ano letivo & Conforme o projeto & Professores \\
\hline
\end{tabular}




\begin{tabular}{|c|c|c|c|c|c|c|c|}
\hline 09 & $\begin{array}{l}\text { Apoiar a educação } \\
\text { básica no } \\
\text { atendimento } \\
\text { educacional } \\
\text { especializado para } \\
\text { o aluno com } \\
\text { necessidades } \\
\text { especiais por meio } \\
\text { de ações } \\
\text { psicopedagógicas, } \\
\text { centradas na } \\
\text { funcionalidade e no } \\
\text { processo de } \\
\text { aquisição do } \\
\text { conhecimento. }\end{array}$ & $\begin{array}{l}\text { Executar ação preventiva } \\
\text { de sensibilização e } \\
\text { divulgação junto às } \\
\text { unidades de ensino e } \\
\text { outras instituições. }\end{array}$ & $\begin{array}{l}\text { Propiciar atendimentos de } \\
\text { acordo com especificidades de } \\
\text { cada aluno. }\end{array}$ & $\begin{array}{l}\text { Avaliar e reavaliar as } \\
\text { crianças com } \\
\text { dificuldades especificas } \\
\text { encaminhadas pelos } \\
\text { profissionais da área } \\
\text { educacional, saúde e } \\
\text { comunidade. } \\
\text { Elaborar relatórios; } \\
\text { Organizar e integrar os } \\
\text { dados para estudo de } \\
\text { caso. }\end{array}$ & Ano letivo & $\begin{array}{l}\text { Humanos: } \\
* \text { Profissionais da } \\
\text { área }\end{array}$ & $\begin{array}{l}\text { Equipe de apoio } \\
\text { a aprendizagem }\end{array}$ \\
\hline 10 & $\begin{array}{l}\text { Realizar visitas } \\
\text { domiciliares }\end{array}$ & $\begin{array}{l}\text { Organizar grupos de } \\
\text { professores para visitas } \\
\text { domiciliares no horário de } \\
\text { coordenação. }\end{array}$ & $\begin{array}{l}\text { Conhecer a realidade social } \\
\text { dos alunos e o ambiente } \\
\text { familiar. }\end{array}$ & $\begin{array}{l}\text { Visitas nos horário de } \\
\text { coordenação com aviso } \\
\text { prévio das mesmas. }\end{array}$ & Semestral & $\begin{array}{l}\text { Humanos: } \\
\text { Profissionais } \\
\text { educação } \\
\text { Transporte } \\
\end{array}$ & $\begin{array}{l}\text { Professores } \\
\text { coordenadores }\end{array}$ \\
\hline 11 & $\begin{array}{l}\text { Promover ações } \\
\text { pedagógicas com a } \\
\text { orientadora } \\
\text { pedagógica e a } \\
\text { equipe de apóio a }\end{array}$ & $\begin{array}{l}\text { Participação nas } \\
\text { coordenações coletivas, } \\
\text { Conselho Escolar, estudos } \\
\text { de caso e conselhos de } \\
\text { classe. }\end{array}$ & $\begin{array}{l}\text { Contribuir na sensibilização do } \\
\text { corpo docente para a } \\
\text { Educação Inclusiva. } \\
\text { Participar na Construção do PPP, } \\
\text { propiciando reflexão sobre a }\end{array}$ & 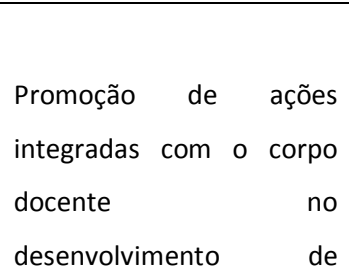 & Ano letivo & $\begin{array}{l}\text { * Recurso humano } \\
\text { Material de } \\
\text { consumo } \\
* \quad \text { TV; Som }\end{array}$ & $\begin{array}{l}\text { Equipe de apoio } \\
\text { à aprendizagem }\end{array}$ \\
\hline
\end{tabular}




\begin{tabular}{|c|c|c|c|c|c|c|c|}
\hline & aprendizagem & $\begin{array}{l}\text { Promover ciclos de } \\
\text { palestras, } \\
\text { pedagógicas e grupos de } \\
\text { vivências com o corpo } \\
\text { docente. }\end{array}$ & prática pedagógica. & $\begin{array}{l}\text { projetos: Saúde, Educação } \\
\text { Sexual, Meio Ambiente e } \\
\text { Cultura da Paz. }\end{array}$ & & & \\
\hline 12 & $\begin{array}{l}\text { O orientador } \\
\text { educacional } \\
\text { acompanhará os } \\
\text { alunos do CEE } 02\end{array}$ & $\begin{array}{l}\text { Acompanhar os alunos } \\
\text { matriculados na EJA } \\
\text { Especial, e no processo de } \\
\text { inclusão. }\end{array}$ & $\begin{array}{l}\text { Contribuir com os docentes no } \\
\text { processo pedagógico dos } \\
\text { alunos do Centro }\end{array}$ & $\begin{array}{l}\text { Acompanhar os alunos da } \\
\text { Educação de Jovens e } \\
\text { Adultos Especiais, e o } \\
\text { processo de inclusão. }\end{array}$ & Ano letivo & $\begin{array}{l}\text { * Orientador } \\
\text { Educacional }\end{array}$ & $\begin{array}{l}\text { Orientador } \\
\text { Educacional }\end{array}$ \\
\hline 13 & $\begin{array}{l}\text { Organizar } \\
\text { palestras para os } \\
\text { pais com } \\
\text { profissionais da } \\
\text { área da saúde }\end{array}$ & $\begin{array}{l}\text { Contactar profissionais } \\
\text { da área da saúde bucal, } \\
\text { pediatra e neuropediatra. }\end{array}$ & $\begin{array}{l}\text { Ampliar o Conhecimento } \\
\text { dos docentes referentes } \\
\text { ao atendimento do aluno }\end{array}$ & $\begin{array}{l}\text { Palestras; } \\
\text { Seminários; }\end{array}$ & Ano letivo & Profissionais da área & $\begin{array}{l}\text { Coordenação } \\
\text { precoce }\end{array}$ \\
\hline 14 & $\begin{array}{l}\text { Organizar oficina } \\
\text { pedagógica com a } \\
\text { confecção de } \\
\text { brinquedos com } \\
\text { material de sucata. }\end{array}$ & $\begin{array}{l}\text { Campanha para arrecadar } \\
\text { materiais recicláveis junto à } \\
\text { comunidade. Fazer } \\
\text { divulgação na comunidade } \\
\text { escolar. }\end{array}$ & $\begin{array}{l}\text { Propiciar conhecimentos aos } \\
\text { profissionais de educação e } \\
\text { aos pais referentes ao } \\
\text { reaproveitamento de materiais } \\
\text { descartáveis na confecção de } \\
\text { brinquedos pedagógicos para } \\
\text { favorecer o aprendizado do }\end{array}$ & $\begin{array}{l}\text { Confecção de } \\
\text { brinquedos pedagógicos } \\
\text { adaptados para o aluno. }\end{array}$ & $2^{\circ}$ semestre & $\begin{array}{l}\text { Materiais } \\
\text { recicláveis. } \\
* \quad \text { Cola. } \\
* \quad \text { Papéis. } \\
* \quad \text { Tesouras. } \\
\text { Estilete. }\end{array}$ & $\begin{array}{l}\text { Direção, } \\
\text { Professores, } \\
\text { coordenação. }\end{array}$ \\
\hline
\end{tabular}




\begin{tabular}{|c|c|c|c|c|c|c|c|}
\hline & & & aluno e ao meio ambiente. & & & & \\
\hline 15 & $\begin{array}{l}\text { Ampliar e melhorar } \\
\text { o atendimento de } \\
\text { educação física } \\
\text { aos alunos. }\end{array}$ & $\begin{array}{l}\text { Realizar atendimentos } \\
\text { diversos, respeitando as } \\
\text { limitações e valorizando o } \\
\text { potencial do aluno, por } \\
\text { meio de atividades } \\
\text { lúdicas. }\end{array}$ & $\begin{array}{l}\text { Propiciar atendimentos de } \\
\text { acordo com especificidades de } \\
\text { cada aluno. }\end{array}$ & $\begin{array}{l}\text { Jogos; } \\
\text { Brincadeiras; } \\
\text { Alongamentos; }\end{array}$ & Ano letivo & $\begin{array}{l}\text { Materiais: } \\
* \quad \text { Bolas. } \\
* \quad \text { Cordas. } \\
* \quad \text { Balão. Rampas. } \\
\text { E outros }\end{array}$ & $\begin{array}{l}\text { Professores de } \\
\text { Educação física }\end{array}$ \\
\hline 16 & $\begin{array}{l}\text { Promover ações } \\
\text { pedagógicas para } \\
\text { a realização de } \\
\text { atividades culturais }\end{array}$ & $\begin{array}{l}\text { Realizar danças, festa } \\
\text { juninas e folclóricas. } \\
\text { Buscar recursos }\end{array}$ & $\begin{array}{l}\text { Propiciar o elo entre a família } \\
\text { e a escola. }\end{array}$ & $\begin{array}{l}\text { Realizar bazar } \\
\text { Reuniões com os } \\
\text { interessados } \\
\text { * Participação nos } \\
\quad \text { eventos; } \\
\text { \&esta junina; } \\
\text { Semana cultural }\end{array}$ & Junho/agosto & \begin{tabular}{|l} 
Materiais: \\
* Roupas e \\
típicas; \\
$*$ Som; \\
$*$ Microfone;
\end{tabular} & $\begin{array}{l}\text { Grupo de } \\
\text { professores de } \\
\text { Educação física }\end{array}$ \\
\hline 17 & $\begin{array}{l}\text { Divulgar } \\
\text { acontecimentos } \\
\text { nacionais e } \\
\text { internacionais }\end{array}$ & Campeonato de futebol & $\begin{array}{l}\text { Divulgar as atividades de } \\
\text { educação física oferecidas no } \\
\text { CEE- } 02 \text { nos eventos mundiais }\end{array}$ & $\begin{array}{l}\text { Confecção de materiais: } \\
\text { Tabelas de jogo; } \\
\text { Bandeiras; exibição de } \\
\text { jogos para os alunos. }\end{array}$ & Junho/ julho & $\begin{array}{l}\text { Matérias: } \\
\text { Isopor; tinta; cola; papel } \\
\text { comum; TNT; EVA; }\end{array}$ & \\
\hline & $\begin{array}{l}\text { Realizar os jogos } \\
\text { da Primavera e } \\
\text { Festival Recreativo } \\
\text { de Ceilândia }\end{array}$ & $\begin{array}{l}\text { Realizar jogos que } \\
\text { propiciem a integração } \\
\text { dos alunos e professores } \\
\text { do centro e com outras }\end{array}$ & $\begin{array}{l}\text { Interação entre alunos pais e } \\
\text { professores, outras I.E e } \\
\text { comunidade escolar. }\end{array}$ & $\begin{array}{l}\text { Reunião; planejamento } \\
\text { Realização dos jogos } \\
\text { FREC; } \\
\text { Avaliação com todos os }\end{array}$ & $2^{\circ}$ semestre & Materiais esportivos & $\begin{array}{l}\text { Grupo de } \\
\text { educação física. }\end{array}$ \\
\hline
\end{tabular}




\begin{tabular}{|c|c|c|c|c|c|c|c|}
\hline & & escolas. & & profissionais envolvidos. & & & \\
\hline 18 & $\begin{array}{l}\text { Oferecer passeios. } \\
\text { Atividades extra } \\
\text { classes e visitas de } \\
\text { acordo com os } \\
\text { objetivos traçados. }\end{array}$ & $\begin{array}{l}\text { Organizar cronograma de } \\
\text { visitas em diversos } \\
\text { lugares a serem definidos } \\
\text { posteriormente, para } \\
\text { maior socialização e } \\
\text { integração social. }\end{array}$ & $\begin{array}{l}\text { Desenvolver } \\
\text { consciência de si, bem } \\
\text { como o contexto social } \\
\text { em que está inserido. } \\
\text { Propiciar momentos de } \\
\text { lazer em diferentes } \\
\text { lugares }\end{array}$ & $\begin{array}{l}\text { Realizar saídas de } \\
\text { campo aos seguintes } \\
\text { locais; } \\
\text { EMBRAPA; } \\
\text { Teatro/cinema; } \\
\text { Feiras } \\
\text { culturais/ciências; } \\
\text { Clubes esportivos. } \\
\text { Atividades psicomotoras, } \\
\text { lúdicas e culturais: } \\
\text { Passeios; atividades } \\
\text { coletivas. }\end{array}$ & Ano letivo & $\begin{array}{l}\text { Humanos: } \\
\text { coordenadores; } \\
\text { Professores, alunos. } \\
\text { Material de apoio } \\
\text { Escolar; Lanche; } \\
\text { Recursos financeiros. }\end{array}$ & $\begin{array}{l}\text { Coordenadores/ } \\
\text { professores/ } \\
\text { parcerias. }\end{array}$ \\
\hline 19 & $\begin{array}{l}\text { Melhorar a } \\
\text { estrutura física e } \\
\text { material da escola }\end{array}$ & $\begin{array}{l}\text { Realizar eventos para } \\
\text { complementar a verba do } \\
\text { PDRF com intuito de } \\
\text { melhorar tal estrutura } \\
\text { física. } \\
\text { Buscar parcerias }\end{array}$ & $\begin{array}{l}\text { Priorizar as instalações das } \\
\text { áreas de educação física. Com } \\
\text { intuito de beneficiar os } \\
\text { atendimentos dos alunos. }\end{array}$ & $\begin{array}{l}\text { Manutenções para: } \\
\begin{array}{l}\text { Funcionamento da } \\
\text { piscina externa; }\end{array} \\
\text { * Cobertura da área } \\
\text { da piscina e da } \\
\text { quadra } \\
\text { poliesportiva; } \\
\text { Instalar sons } \\
\text { portáteis nas salas } \\
\text { de aula; } \\
\text { Implantação do } \\
\text { Laboratório de }\end{array}$ & Ano letivo & $\begin{array}{l}\text { Profissionais da área de } \\
\text { engenharia } \\
\text { Materiais: } \\
\text { * Cimento; tintas; } \\
\text { Ionas; } \\
\text { * Estabilizadores; } \\
\text { Computadores } \\
\text { * Grama; tabelas; } \\
\text { * Parquinho de } \\
\text { plásticos }\end{array}$ & SEEDF/Direção \\
\hline
\end{tabular}




\begin{tabular}{|c|c|c|c|c|c|c|c|c|}
\hline & & & & & $\begin{array}{l}\text { informática; } \\
\text { * Construção do } \\
\text { campo de futebol; } \\
\text { * Criação do parque } \\
\text { para os alunos } \\
\text { maiores. }\end{array}$ & & & \\
\hline 20 & $\begin{array}{l}\text { Viabilizar um } \\
\text { parque } \\
\text { (playground) } \\
\text { grande na área } \\
\text { externa da escola }\end{array}$ & & $\begin{array}{l}\text { Promover festas e } \\
\text { eventos com fins } \\
\text { lucrativos e requisitar a } \\
\text { responsabilidade de } \\
\text { nossos representantes } \\
\text { no campo político }\end{array}$ & $\begin{array}{l}\text { Desenvolver a atividade } \\
\text { psicomotora do educando. }\end{array}$ & & Ano letivo & $\begin{array}{l}\text { * Recursos Humanos } \\
\text { Contribuição do } \\
\text { comércio local } \\
\text { Ofícios aos órgãos } \\
\text { competentes }\end{array}$ & $\begin{array}{l}\text { Equipe diretiva/ } \\
\text { parcerias }\end{array}$ \\
\hline 21 & $\begin{array}{l}\text { Buscar meios de } \\
\text { controlar o acesso } \\
\text { da comunidade no } \\
\text { ambiente escolar }\end{array}$ & $\%$ & $\begin{array}{l}\text { Reativar o portão } \\
\text { eletrônico; } \\
\text { Implantar "carteirinha } \\
\text { de identificação" para } \\
\text { os acompanhantes de } \\
\text { alunos e crachá para os } \\
\text { visitantes }\end{array}$ & $\begin{array}{l}\text { Oferecer maior segurança } \\
\text { aos educando e o corpo } \\
\text { docente }\end{array}$ & $\begin{array}{l}\text { Implantar "carteirinha de } \\
\text { identificação" para os } \\
\text { acompanhantes de } \\
\text { alunos e crachá para os } \\
\text { visitantes e uso do } \\
\text { uniforme para os alunos }\end{array}$ & Ano letivo & $\begin{array}{l}\text { - Papeis } \\
\text { Plastificação } \\
\text { Recursos humanos }\end{array}$ & $\begin{array}{l}\text { Direção/ } \\
\text { SEEDF/ PDRF }\end{array}$ \\
\hline 22 & $\begin{array}{lr}\text { Investir } & \text { em } \\
\text { melhorias } & \text { nos } \\
\text { banheiros } & \text { dos } \\
\text { servidores } & \text { do } \\
\text { Centro e no } & \text { dos }\end{array}$ & & $\begin{array}{l}\text { Realizar festas com fins } \\
\text { lucrativos e bazar }\end{array}$ & $\begin{array}{l}\text { Adquirir um ambiente } \\
\text { agradável de trabalho } \\
\text { para os funcionários }\end{array}$ & $\begin{array}{l}\text { Manutenção } \\
\text { sanitários }\end{array}$ & Ano letivo & $\begin{array}{l}\text { Participação de } \\
\text { comunidade escolar. da } \\
\text { área de obras da SEEDF } \\
\text { Administração Regional }\end{array}$ & SEEDF/PDRF \\
\hline
\end{tabular}




\begin{tabular}{|c|c|c|c|c|c|c|c|}
\hline & discentes & & & & & & \\
\hline 23 & Reformar auditório, & $\begin{array}{l}\text { Contato com comércio } \\
\text { local, Participar aos órgãos } \\
\text { responsáveis a nossa } \\
\text { necessidade. }\end{array}$ & $\begin{array}{l}\text { Melhorar os assentos para } \\
\text { viabilizar palestras reuniões, } \\
\text { os estudos aos profissionais } \\
\text { da escola principalmente no } \\
\text { tocante aos bancos. }\end{array}$ & $\begin{array}{l}\text { Reforma dos assentos, } \\
\text { pinturas; colocação de } \\
\text { ventiladores, etc. }\end{array}$ & Ano letivo & $\begin{array}{l}\text { Parceiros } \\
\text { Materiais; Tintas; } \\
\text { cadeiras; ventiladores, } \\
\text { lâmpadas; fechaduras. }\end{array}$ & \\
\hline 24 & $\begin{array}{l}\text { Promover } \\
\text { atividades extra } \\
\text { classes } \\
\text { contemplando as } \\
\text { áreas trabalhadas } \\
\text { no atendimento } \\
\text { complementar, }\end{array}$ & $\begin{array}{lr}\text { Compartilhar } & \\
\text { momentos de } \\
\text { interação } & \text { e } \\
\text { aprendizado com o } \\
\text { grupo docente e } \\
\text { discente do CEE-02 e } \\
\text { demais I.E. }\end{array}$ & $\begin{array}{l}\text { Propiciar momentos de } \\
\text { lazer aos alunos }\end{array}$ & $\begin{array}{l}\text { Participação dos alunos } \\
\text { em eventos dentro e fora } \\
\text { da escola: } \\
\text { Palestras e Oficinas. }\end{array}$ & Ano letivo & $\begin{array}{l}\text { - Recursos } \\
\text { audiovisuais } \\
\text { Profissionais de outras } \\
\text { áreas }\end{array}$ & $\begin{array}{l}\text { Professores } \\
\text { atendimento } \\
\text { complementar/ } \\
\text { parcerias }\end{array}$ \\
\hline 25 & $\begin{array}{lr}\text { Reconhecer } & \text { a } \\
\text { importância do } & \text { do } \\
\text { respeito } & \text { ao } \\
\text { cidadão deficiente }\end{array}$ & $\begin{array}{l}\text { Sensibilizar a família sobre a } \\
\text { importância de conhecer a } \\
\text { entidade que garantam os } \\
\text { direitos da pessoa com } \\
\text { deficiência }\end{array}$ & $\begin{array}{l}\text { Desenvolver respeito à pessoa } \\
\text { com deficiência no contexto } \\
\text { escolar e comunitário. }\end{array}$ & $\begin{array}{l}\text { Comemoração do dia } \\
\text { da pessoa com } \\
\text { deficiência }\end{array}$ & Ano letivo & $\begin{array}{ll}\text { - } & \text { Recursos } \\
& \text { audiovisuais; } \\
\text { - } & \text { Transporte; } \\
& \text { Profissionais de } \\
\text { outras áreas } \\
\text { Palestras; oficinas }\end{array}$ & $\begin{array}{l}\text { Professore } \\
\text { s / } \\
\text { coordenado } \\
\text { res / equipe } \\
\text { pedagogica } \\
\text { /Profissiona } \\
\text { is de outras } \\
\text { áreas }\end{array}$ \\
\hline 26 & $\begin{array}{l}\text { Realização de } \\
\text { conselho de classe }\end{array}$ & $\begin{array}{l}\text { Realizar conselho de classe } \\
\text { com ênfase na melhor } \\
\text { adequação da turma para o } \\
\text { desenvolvimento do aluno }\end{array}$ & $\begin{array}{l}\text { Evitar formação de conflitos } \\
\text { "respeitando a individualidade } \\
\text { de cada um". }\end{array}$ & $\begin{array}{l}\text { Relatório de estudo } \\
\text { de caso }\end{array}$ & Bimestral & $\begin{array}{l}\text { Recursos humanos; } \\
\text { Diários; } \\
\text { Planejamento; } \\
\text { Relatórios. } \\
\end{array}$ & $\begin{array}{l}\text { Coordenação/ } \\
\text { professores e } \\
\text { equipe } \\
\text { pedagógica }\end{array}$ \\
\hline 27 & $\begin{array}{l}\text { Implantar projeto } \\
\text { comum a todos }\end{array}$ & $\begin{array}{l}\text { Discutir as ações durante as } \\
\text { coordenações r com } \\
\text { planejamento }\end{array}$ & $\begin{array}{l}\text { Nortear o trabalho pedagógico } \\
\text { Diversificar as atividades no } \\
\text { ambiente escolar }\end{array}$ & $\begin{array}{l}\text { Respeitar } \\
\text { especificidades de cada } \\
\text { projeto por área a ser } \\
\text { desenvolvido }\end{array}$ & Bimestre & $\begin{array}{ll} & \text { Humanos } \\
\text { - } & \text { Materiais } \\
& \text { reproduzidos; } \\
\text { - } & \text { Livro; } \\
\text { - } & \text { Data show } \\
\text { Pátio da escola } \\
\text { - } & \text { Som, DVD, TV; }\end{array}$ & $\begin{array}{l}\text { Coordenação/ } \\
\text { professores e }\end{array}$ \\
\hline
\end{tabular}




\begin{tabular}{|c|c|c|c|c|c|c|c|}
\hline 28 & $\begin{array}{l}\text { Conscientizar a } \\
\text { todos sobre } \\
\text { atitudes e atos que } \\
\text { beneficiam a saúde }\end{array}$ & $\begin{array}{l}\text { Realizar contatos com } \\
\text { profissionais da área } \\
\text { de saúde }\end{array}$ & $\begin{array}{l}\text { Contribuir na sensibilização do } \\
\text { corpo docente para } \\
\text { desenvolvimento do trabalho } \\
\text { pedagógico }\end{array}$ & \begin{tabular}{l}
\multicolumn{2}{l}{ Atividades como circuito e } \\
apresentações no \\
auditório, além de \\
sensibilização.
\end{tabular} & Ano letivo & $\begin{array}{ll}* & \text { Panfletos } \\
\text { * } & \text { Materiais de saúde } \\
\text { Contato com } \\
\text { profissionais da } \\
\text { saúde }\end{array}$ & $\begin{array}{l}\text { Profissionais da } \\
\text { saúde }\end{array}$ \\
\hline 29 & $\begin{array}{l}\text { Adquirir mobiliário } \\
\text { adaptado para o } \\
\text { aluno }\end{array}$ & $\begin{array}{l}\text { Buscar parcerias com SEDF- } \\
\text { seção patrimônio }\end{array}$ & $\begin{array}{l}\text { Melhorar o atendimento ao } \\
\text { aluno }\end{array}$ & $\begin{array}{l}\text { Fazer levantamento nas } \\
\text { áreas de atendimento } \\
\text { Solicitação do material }\end{array}$ & Ano letivo & $\begin{array}{l}\text { Carteiras e cadeiras } \\
\text { adaptadas }\end{array}$ & SEEDF/PDRF \\
\hline 30 & $\begin{array}{l}\text { Diversificar as } \\
\text { atividades no } \\
\text { ambiente escolar }\end{array}$ & Elaborar projetos por área & $\begin{array}{l}\text { Oportunizar aos alunos maior } \\
\text { diversidade sócio cultural }\end{array}$ & $\begin{array}{l}\text { Através de atividades } \\
\text { com teatro danças ou } \\
\text { demais manifestações } \\
\text { culturais. }\end{array}$ & Mensal & $\begin{array}{l}\text { Espaço físico da escola; } \\
\text { Auditório } \\
\text { Som; DVD; data show. }\end{array}$ & $\begin{array}{l}\text { Professores } \\
\text { currículo } \\
\text { adaptado }\end{array}$ \\
\hline 31 & $\begin{array}{l}\text { Oferecer ao aluno } \\
\text { a oportunidade de } \\
\text { criar diferentes } \\
\text { produtos } \\
\text { artesanais }\end{array}$ & $\begin{array}{l}\text { Produzir diferentes } \\
\text { produtos artesanais com } \\
\text { papéis reciclados }\end{array}$ & $\begin{array}{l}\text { Preparar o aluno para } 0 \\
\text { mercado informal de trabalho }\end{array}$ & $\begin{array}{l}\text { Confecção de papéis } \\
\text { reciclados com aulas } \\
\text { expositivas }\end{array}$ & $\begin{array}{l}\text { Ano letivo - } \\
2010 / 2011\end{array}$ & $\begin{array}{l}\text { Reaproveitamento de } \\
\text { papéis utilizados na } \\
\text { escola; retalhos de } \\
\text { tecidos cores variadas; } \\
\text { - } \quad \text { Folhas secas; } \\
\quad \text { colhidas no espaço } \\
\text { físico da escola, } \\
\text { entre outros; } \\
\text { Liquidificador; } \\
\text { peneira; cubas; } \\
\text { varal; entre outros. }\end{array}$ & $\begin{array}{l}\text { Professores e } \\
\text { coordenadores; } \\
\text { direção. }\end{array}$ \\
\hline 32 & $\begin{array}{l}\text { Possibilitar a } \\
\text { inserção do aluno } \\
\text { no mercado forma } \\
\text { e informal de } \\
\text { trabalho }\end{array}$ & $\begin{array}{l}\text { Providenciar } \\
\text { documentação } \\
\text { Buscar parcerias nos } \\
\text { órgãos responsáveis }\end{array}$ & $\begin{array}{l}\text { Proporcionar a autonomia e } \\
\text { independência financeira do } \\
\text { aluno }\end{array}$ & $\begin{array}{l}\text { Fazer levantamento dos } \\
\text { educando sem } \\
\text { documentação } \\
\text {-Realizar palestras, } \\
\text { cursos, pesquisas } \\
\text { referentes perspectivas } \\
\text { do mercado de trabalho. }\end{array}$ & - & - Materiais didáticos & $\begin{array}{l}\text { Professores } \\
\text { regentes ( EJA, } \\
\text { OFICINAS, } \\
\text { SOT) }\end{array}$ \\
\hline
\end{tabular}




\begin{tabular}{|c|c|c|c|c|c|c|c|}
\hline 33 & Promover oficinas & $\begin{array}{l}\text { Sondagem do público } \\
\text { alvo } \\
\text { Agendamento } \\
\text { palestrante. }\end{array}$ & $\begin{array}{l}\text { Promover } \\
\text { profissional }\end{array}$ & $\begin{array}{lr}\text { Nos horários } & \text { de } \\
\text { coordenação } & \text { dos } \\
\text { professores na própria } \\
\text { escola ou } & \text { nas } \\
\text { proximidades } & \end{array}$ & Semestral & $\begin{array}{ll}* & \text { Buscar parceria com } \\
& \text { EEEE/SOE, direção } \\
& \text { GREC; } \\
* \quad \text { Palestrantes; } \\
\text { - } \\
\text { Materiais } \\
\text { tecnológicos da I.E, }\end{array}$ & $\begin{array}{l}\text { Coordenação, } \\
\text { equipe gestora } \\
\text { com } \\
\text { supervisão- } \\
\text { EAPE. }\end{array}$ \\
\hline 34 & $\begin{array}{l}\text { Estruturar a horta e } \\
\text { os jardins da } \\
\text { escola }\end{array}$ & $\begin{array}{l}\text { Cultivar hortaliças e } \\
\text { plantas medicinais } \\
\text { podendo ser estendida a } \\
\text { todas as áreas de } \\
\text { atendimento, }\end{array}$ & $\begin{array}{l}\text { Oferecer condições para a } \\
\text { oficina de práticas agrícola, } \\
\text { realizar o trabalho com os } \\
\text { jardins e horta, cultivando } \\
\text { hortaliças } \\
\text { medicinais, bem como flores. }\end{array}$ & $\begin{array}{l}\text { Incluir os pais no projeto } \\
\text { Realizar o trabalho com } \\
\text { os jardins e horta, } \\
\text { cultivando hortaliças e } \\
\text { plantas medicinais, bem } \\
\text { como flores. }\end{array}$ & Ano letivo & $\begin{array}{l}\text { - } \quad \text { Adubo. } \\
\text { - } \quad \text { Mudas. } \\
\text { Ferramentas }\end{array}$ & $\begin{array}{l}\text { Professor } \\
\text { atendimento } \\
\text { complementar }\end{array}$ \\
\hline 35 & $\begin{array}{ll}\text { Arborizar } & \text { os } \\
\text { arredores } & \text { da } \\
\text { escola } & \end{array}$ & $\begin{array}{l}\text { Plantar arvores frutíferas e } \\
\text { ornamentais próximo ao } \\
\text { muro da escola }\end{array}$ & $\begin{array}{l}\text { Oferecer ambiente saudável } \\
\text { com sombras e frutos. }\end{array}$ & $\begin{array}{l}\text { Plantio de mudas ou } \\
\text { sementes de árvores do } \\
\text { cerrado e/ ou } \\
\text { ornamentais }\end{array}$ & Ano letivo & $\begin{array}{l}\text { Uso de mudas e } \\
\text { sementes de árvores. }\end{array}$ & $\begin{array}{l}\text { Professores } \\
\text { Auxiliares }\end{array}$ \\
\hline 36 & $\begin{array}{lr}\begin{array}{l}\text { Ampliação } \\
\text { adequação } \\
\text { casinha }\end{array} & \text { da } \\
\text { las } & \end{array}$ & $\begin{array}{l}\text { - Equipar o ambiente } \\
\text { adequadamente; } \\
\text { - Ampliar a casinha; } \\
\text { - Verificar e adequar às } \\
\text { portas. o }\end{array}$ & $\begin{array}{l}\text { Proporcionar um ambiente que } \\
\text { promova o desenvolvimento } \\
\text { do jogo simbólico. }\end{array}$ & $2^{\circ}$ semestre & $\begin{array}{ll}\text { Equipe } & \text { do } \\
\text { Programa } & \text { de } \\
\text { Educação } & \\
\text { Precoce } & \end{array}$ & $\begin{array}{l}\text { - Comprar brinquedos } \\
\text { adequados; } \\
\text { - Procurar doadores } \\
\text { entre a comunidade } \\
\text { escolar. }\end{array}$ & $\begin{array}{l}\text { - Doações de } \\
\text { mão-de-obra; } \\
\text { - }\end{array}$ \\
\hline 37 & $\begin{array}{l}\text { Realizar Oficina } \\
\text { Pedagógica }\end{array}$ & $\begin{array}{l}\text { - Montar oficina } \\
\text { pedagógica com os pais } \\
\text { de alunos do programa; }\end{array}$ & $\begin{array}{l}\text {-Capacitar os pais de aluno do } \\
\text { programa na confecção de } \\
\text { brinquedos pedagógicos; }\end{array}$ & $\begin{array}{l}\text { Data sugerida: } 08 \text { ou } \\
09 \text { de junho. }\end{array}$ & $\begin{array}{l}\text { Profissionais e } \\
\text { pais de } \\
\text { alunos. }\end{array}$ & $\begin{array}{l}\text { Confeccionar brinquedos } \\
\text { pedagógicos; } \\
\text { - Adequar os brinquedos } \\
\text { de acordo com a faixa } \\
\text { etária da criança } \\
\text {-Atender os pais, nos } \\
\text { dois turnos em apenas } \\
\text { um dia. }\end{array}$ & $\begin{array}{l}\text { Materiais } \\
\text { diversos, } \\
\text { sucatas, . }\end{array}$ \\
\hline
\end{tabular}




\begin{tabular}{|c|c|c|c|c|c|c|c|}
\hline 38 & Passeio & $\begin{array}{l}\text { - parque de areia da } \\
\text { Praça do DI, ao shoping } \\
\text { da cidade; }\end{array}$ & $\begin{array}{l}\text {-Promover a socialização e a } \\
\text { independência dos alunos; }\end{array}$ & Data a definir. & $\begin{array}{l}\text { Equipe do } \\
\text { programa }\end{array}$ & $\begin{array}{l}\text { - alunos inseridos em } \\
\text { turminha da E.P, sem } \\
\text { acompanhantes (mães); } \\
\text { - Desenvolver atividades } \\
\text { de recreação. }\end{array}$ & $\begin{array}{l}\text { Ônibus, lanche, } \\
\text { colchonetes, } \\
\text { brinquedos. }\end{array}$ \\
\hline 39 & Passeio ao clube & $\begin{array}{l}\text { Passeio para o clube da } \\
\text { CAESO. }\end{array}$ & 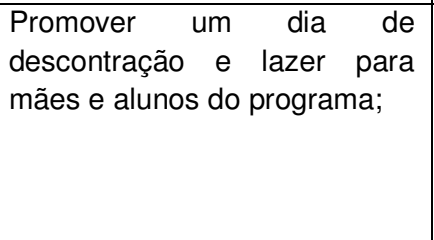 & Data sugerida: maio. & $\begin{array}{ll}\text { Equipe } & \text { do } \\
\text { programa } & \end{array}$ & $\begin{array}{l}\text { Envolver todos os alunos } \\
\text { do programa e suas } \\
\text { mães. }\end{array}$ & $\begin{array}{l}\text { - Ônibus, } \\
\text { lanche, } \\
\text { colchonetes, } \\
\text { brinquedos. e } \\
\text { atestado } \\
\text { médico. }\end{array}$ \\
\hline 40 & $\begin{array}{l}\text { Visita ao Jardim } \\
\text { Botânico }\end{array}$ & $\begin{array}{l}\text { Passeio ao jardim das } \\
\text { sensações }\end{array}$ & $\begin{array}{lr}\text { Promover } & \text { momento } \\
\text { diferenciado para desenvolver } \\
\text { as sensações e percepções } \\
\text { dos alunos. . Data a definir }\end{array}$ & Equipe do programa & $\begin{array}{l}\text { Alunos } \\
\text { inseridos em } \\
\text { turminha da } \\
\text { E.P, sem } \\
\text { acompanhante } \\
\text { s (mães) }\end{array}$ & Ônibus, lanche & \\
\hline 41 & $\begin{array}{ll}\text { Rampa } & \text { de } \\
\text { acessibilidade } & \text { no } \\
\text { parquinho } & \end{array}$ & $\begin{array}{lr}\text { Construção de rampa } \\
\text { para acesso no } \\
\text { parquinho infantil pelos } \\
\text { cadeirantes; }\end{array}$ & $\begin{array}{l}\text { Proporcionar acessibilidade } \\
\text { dos alunos cadeirantes no } \\
\text { parquinho }\end{array}$ & No $1^{\circ}$ semestre. & $\begin{array}{l}\text { Equipe do } \\
\text { programa }\end{array}$ & $\begin{array}{l}\text {-Buscar doadores para } \\
\text { a compra de materiais } \\
\text { de construção; }\end{array}$ & $\begin{array}{lr}\text { Materiais } & \text { de } \\
\text { construção } & \text { e } \\
\text { mão-de-obra } & \end{array}$ \\
\hline 42 & $\begin{array}{l}\text { Trocar brinquedos } \\
\text { do parquinho }\end{array}$ & $\begin{array}{l}\text { Revitalização do } \\
\text { parquinho com } \\
\text { brinquedos de plástico }\end{array}$ & $\begin{array}{l}\text { Promover segurança no } \\
\text { parquinho com brinquedos } \\
\text { adequados. }\end{array}$ & Data a definir & $\begin{array}{ll}\text { Equipe do } \\
\text { programa }\end{array}$ & $\begin{array}{l}\text { Fazer orçamentos dos } \\
\text { brinquedos de plástico; } \\
\text { - montar bazar e rifas } \\
\text { para arrecadação de } \\
\text { recursos }\end{array}$ & $\begin{array}{l}\text { Recursos } \\
\text { oriundos de } \\
\text { bazar e rifas }\end{array}$ \\
\hline 43 & $\begin{array}{l}\text { Ginástica laboral } \\
\text { para professores }\end{array}$ & $\begin{array}{l}\text { Montar um quadro } \\
\text { orientador/demonstrativo } \\
\text { com a sequência de } \\
\text { movimentos para }\end{array}$ & $\begin{array}{l}\text { Oferecer ginástica laboral para } \\
\text { os professores nos início, no } \\
\text { intervalo e ao final dos } \\
\text { atendimentos; }\end{array}$ & Imediato & $\begin{array}{ll}\text { Equipe } & \text { do } \\
\text { programa } & \end{array}$ & $\begin{array}{l}\text { Montar um quadro } \\
\text { orientador/demonstrativo } \\
\text { com fotos, nas salas de } \\
\text { aula e a sequência de } \\
\text { movimentos para }\end{array}$ & Fotos e quadros \\
\hline
\end{tabular}




\begin{tabular}{|c|c|c|c|c|c|c|c|}
\hline & & alongamento. & & & & alongamento. & \\
\hline 44 & $\begin{array}{l}\text { Palestras para } \\
\text { pais: }\end{array}$ & $\begin{array}{l}\text { Palestras para os pais: } \\
\text { a) Síndrome de Down - } \\
\text { Dr. Dennis Alexander } \\
\text { b) Superproteção } \\
\text { (vínculo) } \quad \text { Psicóloga } \\
\text { Denise Percílio } \\
\text { c) Desenvolvimento } \\
\text { Infantil }\end{array}$ & $\begin{array}{l}\text { Oferecer aos pais informações } \\
\text { a respeito de seus filhos e } \\
\text { como lidar com eles no dia-a- } \\
\text { dia }\end{array}$ & $\begin{array}{l}\text { a) } 1^{\circ} \text { semestre } \\
\text { b) } 2^{\circ} \text { semestre } \\
\text { c) } 1^{\circ} \text { semestre }\end{array}$ & $\begin{array}{ll}\text { Equipe } & \text { do } \\
\text { programa } & \end{array}$ & $\begin{array}{l}\text { Convidar os pais para } \\
\text { em um período do dia } \\
\text { para participar de uma } \\
\text { palestra sobre o tema } \\
\text { que escolher. }\end{array}$ & $\begin{array}{l}\text { Data show: } \\
\text { Convite para os } \\
\text { Pais }\end{array}$ \\
\hline 45 & $\begin{array}{l}\text { Formatura das } \\
\text { crianças que sairão } \\
\text { da precoce }\end{array}$ & $\begin{array}{l}\text { Planejamento e execução } \\
\text { do evento. Reunião a ser } \\
\text { realizada com a presença } \\
\text { dos Pais para definição } \\
\text { de prioridades e } \\
\text { estabelecimento de } \\
\text { estratégias. }\end{array}$ & $\begin{array}{l}\text { Proporcionar um momento de } \\
\text { despedida do } \\
\text { Programa dos alunos que } \\
\text { completarão } 4 \text { anos até } \\
30.06 .2011\end{array}$ & . Final do Ano de 2010 & $\begin{array}{lr}\text { Equipe do } & \text { do } \\
\text { programa } & \mathrm{e} \\
\text { pais de alunos }\end{array}$ & $\begin{array}{l}\text { Feito a partir do } \\
\text { levantamento das } \\
\text { expectativas dos pais e } \\
\text { professores. }\end{array}$ & $\begin{array}{l}\text { Materiais } \\
\text { adequados para } \\
\text { realização do } \\
\text { evento }\end{array}$ \\
\hline
\end{tabular}




\section{XV- CRONOGRAMA}

\begin{tabular}{|l|l|}
\hline Data & Atividade \\
\hline Baile de Carnaval & Fevereiro \\
\hline Dia Internacional da mulher & março \\
\hline Cinema na Escola & Mensal \\
\hline Hora Cívica & Mensal \\
\hline Festa dos aniversariantes & Trimestral \\
\hline Páscoa & $31 / 03$ \\
\hline Festa Junina & Junho \\
\hline Festividades da Copa & Junho/Julho \\
\hline Festa da Família & Agosto \\
\hline Feria Cultural & Agosto \\
\hline Caminhada Ecológica & Setembro \\
\hline $\begin{array}{l}\text { Festiva Recreativo Especial } \\
\text { Ceilândia }\end{array}$ & Setembro \\
\hline Comemoração :Semana da Criança & Outubro \\
\hline Dia dos Professores & Outubro \\
\hline Festa de Natalina & Dezembro \\
\hline
\end{tabular}

OBS: Todas as datas comemorativas são trabalhadas em nossa proposta mensal e tem a culminância nas apresentações proporcionadas em "Hora Cívica". As datas acima citadas, acontecem com envolvimento de todos e aberto a comunidade escolar (festas, eventos, exposições, passeio...). 
Equipe Gestora:

Diretora:

Vice diretora

Supervisora Pedagógica

Supervisora administrativa

Chefe de secretaria

Ceilândia, 29/04/2010 


\section{Referências}

BRASIL, A Construção da Proposta Pedagógica da Escola: A escola de cara nova. Planejamento. São Paulo: SE/CENP, 2000. Ministério da Educação. Secretaria de Educação Básica. Orientação

Curricular Educação Básica - Ensino Fundamental - Série e Anos Iniciais, 1998.

, Constituição da República Federativa do Brasil. Brasília, Distrito Federal, 1998.

, Lei de Diretrizes e Bases da Educação Nacional - LDB - Lei 9.394 de 1996. Brasília: Câmara dos Deputados, 1997.

, Parâmetros Curriculares Nacionais - PCN de 1999. Brasília

KUENZER, A. Conhecimento e competências no trabalho e na escola. Rio de Janeiro, Boletim Técnico do SENAC, v. 28, n.2, maio/ago., 2002.

PIAGET, Ao Alcance dos Professores. Rio de Janeiro: ao livro técnico, 1975.

PIAGET, Sis estudos de psicologia. RJ, forence universitária LTDA. 1995.

PORTAL ENSINANDO, Projeto Político Pedagógico/ A Identidade da Escola -

Sistema de Ensino Portal Educação e Sites Associados. Disponível em:

http://www.portaleducacao.com.br/pedagogia/artigos/3550/projeto-politico-

pedagogico-a-identidade-da-escola. Acesso em: 10 de março de 2010

VILLAS BOAS, Benigna Mํㅡㄹ de F. O projeto político-pedagógico e a avaliação. In: VEIGA, IIma P. A. e RESENDE, Lúcia Maria G. de (Orgs). Escola: espaço do projeto político-pedagógico. São Paulo: Papirus, 1998.

VYGOTSKY, L. S. A Formação Social da Mente. São Paulo, Martins Fontes, 1991;

Vygotsky, L. S. - Pensamento e Linguagem. São Paulo. Martins Fontes, 1999

WALLON. Psicologia e Educação da Infância. Lisboa: Ed. Estampa, 1975 